\title{
The Weeks When Decades Happened: A Theoretical Consideration of the 2011 Egyptian Uprising
}

\author{
Rebekah Anna Jónsdottir Menzies
}

A thesis submitted to Victoria University of Wellington

in fulfilment of the requirements for

the degree of Master of Arts

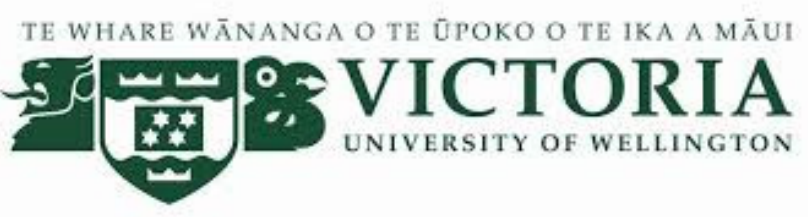

May 2014 


\begin{abstract}
In 2011, the Middle East was plunged into turmoil with a series of popular uprisings ousting a number of long standing dictators. Former Egyptian President Hosni Mubarak's 30 year reign was toppled in just over two weeks. This thesis takes a theoretical approach to the Egyptian Revolution, assessing the extent to which the Egyptian case lends support to various theories which consider transitions away from authoritarianism and towards democracy, and the extent to which these theories can assist us in understanding why democracy has not resulted in Egypt.
\end{abstract}

There are a number of strands of theoretical work which consider both transitions away from authoritarianism and towards democracy, and the factors influencing the timing and mode of transition. These include structural theories related to economic modernisation, inequality and crisis; those related to the role of elites and civil society in influencing transitions, whether from above or below; ideas surrounding the diffusion of, and international influences on, democratisation; and arguments considering the role of religion and culture.

This thesis argues that theories of authoritarian breakdown garner more support from the Egyptian case than theories of democratisation. Ideas related to the diffusion of contentious politics and international influences on transition, as well as the role of both elites and civil society, garner support from the Egyptian case. Structural theories related to economic conditions, and the role of religion and culture, garner less support from events in Egypt. 


\section{Acknowledgements}

First, I would like to thank my supervisor, Dr Xavier Marquez, for his continued support over the past 18 months. Dr Marquez was helpful, encouraging, and prompt in his feedback - even from as far away as Spain!

Second, thanks are due to my family and friends for their continued support. Letters of encouragement and internet banking transfers for 'coffee from afar' have been much appreciated.

Third, special thanks are due to Alex, Maxine and Emma for their assistance with proof reading, as well as to Hayden for his continued support and encouragement in particular during the last five months of this process. 


\section{Table of Contents}

INTRODUCTION

Page 1

CHAPTER ONE

Economic Factors

Page 12

Elites \& Civil Society

Page 17

External Actors \& Diffusion

Page 22

Religion \& Culture

Page 26

CHAPTER TWO

Page 29

Nasser's Era, 1952-1970

Page 30

Sadat's Era, 1970-1981

Page 33

Mubarak's Era, 1981-2011

Page 36

CHAPTER THREE

Page 49

The Egyptian Revolution

Page 49

Post-Revolution Egypt

Page 51

CHAPTER FOUR Page 57

The Trigger of Tunisia Page 57

The Revolution Will Be Tweeted

Page 60

'Cognitive Shortcuts' in Egypt Page 63

The Role of International Actors

Page 64

CHAPTER FIVE

Page 73

The Egyptian Military

Page 73

Egyptian Civil Society

Page 79

Influences from Above \& Below

Page 83

CHAPTER SIX

Page 85

Modernisation Theory

Page 85

Economic Inequality

Page 89

Economic Crisis

Page 94

CHAPTER SEVEN

Page 97

Islam is Incompatible with Democracy

Page 97

The Persistence of Authoritarianism

Page 98

The Arab Barometer \& World Values Survey

Page 100

Reconciling Islam \& Democracy

Page 102

CONCLUSION

Page 105

BIBLIOGRAPHY

Page 111 


\section{List of Acronyms}

\begin{tabular}{ll} 
BMENA & Broader Middle East and North Africa Initiative \\
CANVAS & Centre for Applied Non-Violent Actions and Strategies \\
EMP & Euro-Mediterranean Partnership \\
ENP & European Neighbourhood Policy \\
EU & European Union \\
FAO & Food and Agriculture Organisation \\
GDP & Gross Domestic Product \\
IMF & International Monetary Fund \\
MEPI & Middle East Partnership Initiative \\
NATO & North Atlantic Treaty Organisation \\
NED & National Endowment for Democracy \\
NDP & National Democratic Party \\
NGO & Non-governmental organisation \\
NOVIB & Nederlandse Organisatie Voor Internationale Bijstand \\
RCC & Revolutionary Command Council \\
SCAF & Supreme Council of the Armed Forces \\
SSA & State Security Agency \\
US & United States \\
WTO & World Trade Organisation \\
\hline
\end{tabular}




\section{List of Figures}

Figure One

Support for democracy 


\section{Introduction \& Key Definitions}

Time Magazine's 'Person of the Year' 2011 - The Protestor - provided the inspiration for this thesis. ${ }^{1}$ In December 2010, the now famed self-immolation of a Tunisian street vendor was followed by widespread demonstrations against long-time President Zine El Abidine Ben Ali. These events were the catalyst for a swell of protest across the Middle East and North Africa, on a level unprecedented in the region, if not the world. Major protests occurred in Tunisia, Egypt, Libya and Yemen, where longstanding dictators were toppled in a matter of weeks. Demonstrations led to government changes in Jordan, Bahrain, Kuwait, Oman and Morocco, and minor protests were observed in Algeria, Sudan, Djibouti, Mauritania, Lebanon, Saudi Arabia and Iraq. Syria continues to make headlines over three years later, with protests there descending into a violent civil war, resulting in well over 100,000 deaths and countless more displaced persons, as well as international condemnation directed towards the Assad regime.

This thesis focuses on the case of Egypt, where 18 days of demonstrations resulted in the removal of President Hosni Mubarak. Mubarak had been in power for three decades, and had promised the Egyptian people that he would lead them "as long as there is in my chest a heart that beats." ${ }^{2}$ It takes a theoretical perspective, considering four strands of theory which make up the wider body of literature that considers both transitions away from authoritarianism, and towards democracy. These theories include those which focus on economic conditions, theories related to the role of elites and civil society, ideas relating to external influences and the diffusion of revolution, and theories based on religious and cultural arguments. In this thesis I will critically evaluate each strand of theory against the Egyptian case in order to assess whether or not they are useful for understanding events that have transpired, and why Egypt has not made progress towards democracy.

Despite a resurgence in the literature on transitions away from authoritarianism and towards democracy since the recent Arab Uprisings, much of it is somewhat dated, emerging out of the third wave of transition beginning in the 1970s and lasting into the 1990s. This raises the question of whether or not these theoretical approaches remain useful for understanding contemporary cases

\footnotetext{
1 Time Magazine, "Person of the Year 2011: The Protestor," Time Magazine, 2011, Available Online at: http://content.time.com/time/person-of-the-year/2011/. (Accessed: 11 February 2013)

${ }^{2}$ Gamal Essam El-Din, "Mubarak's most controversial speech," Al-Ahram Weekly, 2006, Available Online at: http://weekly.ahram.org.eg/2006/821/eg1.htm. (Accessed: 23 February 2014)
} 
of authoritarian breakdown and progress towards democracy, like that of Egypt. After reviewing the wider transitions literature in Chapter One, and providing a historical overview of modern authoritarianism in Egypt, as well as the events of the revolution itself in Chapters Two and Three, I will go on to argue that while some theoretical approaches remain useful, others garner less support from the Egyptian case.

Chapter Four will discuss theories relating to the diffusion of revolution across borders, as well as international influences on transition movements. These ideas garner a great deal of support from the Egyptian case. We can see a clear pattern of diffusion emerging from Tunisia and into Egypt and further afield during early 2011, much of which was facilitated by social media channels. We can also observe the democracy promotion efforts of international actors in Egypt, however these are somewhat less important. Chapter Five will cover theories relating to the roles of elites and civil society, which are also supported by the case of Egypt. The involvement of both elites, in the form of the Egyptian military, and civil society groups and the wider Egyptian public were crucial for determining the timing and mode of revolution, and well as the events that have transpired in the post-revolution space.

Other theoretical approaches garner less support from the Egyptian case. Chapter Six will discuss theories relating to economic conditions, including modernisation, economic inequality and economic crisis, which have proved less important for explaining the Egyptian case. In fact, despite being widely cited by both the media and academics as one of the key 'causes' of the revolution, perceptions of economic inequality and crisis have had more of an impact in shaping people's actions as opposed to material economic conditions. Chapter Seven will focus on Orientalist arguments relating to religion and culture that attempt to explain the 'Arab democracy deficit,' which are also unsupported by the Egyptian case. Despite a number of theorists ruling that democracy and Islamic cultures are inherently antagonistic, we can observe support for democracy in Egypt, and the wider region. Despite an unsuccessful brush with Islamist-led democracy in the post-revolution space, the two are not necessarily irreconcilable in Egypt.

\section{Key Definitions}

In order to gain a firm understanding of the theories that consider transitions away from authoritarianism and towards democracy, as well as to properly place the Egyptian case in the period leading up to the 2011 revolution, some key terms must be defined. The following section 
provides definitions of three key terms that are used throughout this thesis: democracy, authoritarianism, and hybrid regimes.

\section{Democracy}

Democracy is a difficult concept, and understandings of what constitutes a functioning democracy are often contested. Schumpeter's minimalist understanding of democracy has provided the basis for various definitions for the past 70 years. After dispelling the classical doctrine of democracy, originating in the $18^{\text {th }}$ century and focusing on the notions of the 'common good' and the 'will of the people, ${ }^{3}$ Schumpeter proposes an alternative theory. He outlines that the primary "role of the people is to produce a government, or else an intermediate body which in turn will produce a national executive or government." ${ }^{4}$ In other words, Schumpeter perceives the public election of officials as the most crucial element of a democracy. A number of scholars have since picked up Schumpeter's ideas. Huntington makes it clear that he does not see a great deal of value in considering the classical notions of liberté, égalité, and fraternité when defining democracy. Instead, he follows the Schumpeterian path, stating: "Fuzzy norms do not yield useful analysis. Elections, open, free, and fair, are the essence of democracy, the inescapable sine qua non." ${ }^{5}$ In their seminal work, O'Donnell and Schmitter develop what they term a "procedural minimum," which outlines the elements that they deem necessarily part of a political democracy. These largely focus on the electoral process, and include secret balloting, universal adult suffrage, regular elections, partisan competition, associational recognition and access, and executive accountability. ${ }^{6}$

However, as discussed by Diamond, ${ }^{7}$ theorists have divergent views when it comes to outlining the specifics of democracy. A number of scholars have argued that placing too much weight on the mere presence of elections is dangerous. Linz and Stepan are among those who address this "electoralist fallacy" whereby elections, as necessary conditions for democracy, are treated almost as if they were sufficient. ${ }^{8}$ These scholars have provided expansions to minimalist concepts of democracy. In his seminal work Polyarchy, Dahl provides one such expansion. The ability to contest a regime through opposition during elections, and the right of all adults to participate through voting and

\footnotetext{
${ }_{3}^{3}$ Joseph A. Schumpeter, Capitalism, Socialism and Democracy, Sixth ed. (London: Unwin Paperbacks, 1987). p. 250.

4 Ibid., p. 269.

${ }^{5}$ Samuel P. Huntington, The Third Wave: Democratization in the Late Twentieth Century, vol. 4 (Norman: University of Oklahoma Press, 1993). p. 9.

${ }^{6}$ Guillermo O'Donnell and Philippe C. Schmitter, Transitions from Authoritarian Rule: Tentative Conclusions about Uncertain Democracies (Baltimore, Maryland: The John Hopkins University Press, 1986). p. 8.

${ }^{7}$ Larry Diamond, Developing Democracy: Toward Consolidation (Baltimore, Maryland: The John Hopkins University Press, 1999). p. 8.

8 Juan J. Linz and Alfred Stepan, Problems of Democratic Transition and Consolidation: Southern Europe, South America, and Post-Communist Europe (Baltimore, MA: The John Hopkins University Press, 1996). p. 4.
} 
running for office, are two overt dimensions of polyarchy put forward by Dahl. ${ }^{9}$ However, as Diamond outlines in his discussion of Dahl's work, the third dimension implicitly embedded in Dahl's concept is that of civil liberty. Diamond states that the two key aspects of polyarchy, opposition and participation, "cannot be truly meaningful.... [without the] freedom to speak and publish dissenting views, freedom to form and join organisations, and alternative sources of information." ${ }^{10}$

In Developing Democracy, Diamond provides the concept of liberal democracy to move beyond the simplicity of electoral democracy. The three key elements of liberal democracy, in addition to those of electoral democracy, include:

[F]irst, the absence of reserved domains of power for the military or other actors not accountable to the electorate, directly or indirectly. Second, in addition to the vertical accountability of rulers to the ruled (secured mainly through elections), it requires the horizontal accountability of officeholders to one another; this constrains executive power and so helps protect constitutionalism, legality, and the deliberative process. Third, it encompasses extensive provisions for political and civil pluralism as well as for individual and group freedoms, so that contending interests and values may be expressed and compete through on-going processes of articulation and representation, beyond periodic elections. ${ }^{11}$

O'Donnell and Schmitter assent that these elements of liberal democracy are important. However, they argue that it may not be appropriate to discuss them in the context of transitions from authoritarianism to democracy. Instead, they see these elements as characteristic of more "complete" democracies, as opposed to those who have only recently begun transition efforts. ${ }^{12}$

The minimalist understanding of electoral democracy put forward by Schumpeter, and advocated by many since, is problematic. Critics claim that the holding of elections cannot be considered the pinnacle of democracy. Instead, as Nwosu makes clear, "they are necessary conditions for fulfilment of the main reason for the existence of government, ${ }^{\prime 13}$ nothing more. However, as O'Donnell and Schmitter argue, the concept of electoral democracy may prove useful when considering cases of democratic transition, as in these cases countries are unlikely to satisfy the fuller requirements of liberal democracy. Therefore, a robust understanding of electoral democracy appears an appropriate measure for defining the beginnings of democracy in a country attempting to extract itself from authoritarian rule. Egypt met the conditions for a minimal definition of democracy in the period after Mubarak's removal, with the election of Morsi to the presidency. However, Egypt has since slipped back in the direction of authoritarianism.

\footnotetext{
${ }^{9}$ Robert A. Dahl, Polyarchy: Participation and Opposition (New Haven: Yale Universty Press, 1971). p. 2.

${ }^{10}$ Diamond, Developing Democracy: p. 8.

11 Ibid., pp. 10-11.

12 O'Donnell and Schmitter, Transitions from Authoritarian Rule: p. 8.

${ }^{13}$ Bernard Ugochukwu Nwosu, "Tracks of the third wave: democracy theory, democratisation and the dilemma of political succession in Africa," Review of African Political Economy 39, no. 131 (2012): p. 16.
} 


\section{Authoritarianism}

Linz and Stepan base their basic understanding of authoritarianism around four key characteristics. First, political pluralism in authoritarian systems is limited and not responsible. However, extensive social and economic pluralism can often be observed. Second, authoritarian systems lack a definitive guiding ideology, but do possess distinctive mentalities. Third, an authoritarian political system lacks mobilisation. Fourth, the leadership of an authoritarian regime consists of a single leader or small group who exercise power in a somewhat predictable manner. ${ }^{14}$

Throughout the literature, there are a number of scholars who have distinguished between different types of authoritarianism, moving beyond the overly simplistic distinction of non-democratic regimes as either totalitarian or authoritarian, appreciating that "different kinds of authoritarianism differ from each other as much as they differ from democracy." ${ }^{15}$ Geddes identifies three types of authoritarian regimes: military, single-party, and personalist. Military regimes are ruled and influenced by a group of military officers, whereas single-party regimes are defined by the control of one key political party. Personalist regimes are different again, with political control centralised in the hands of an individual leader. This individual may have ties to the military or a certain political party, however they exercise control over these bodies as well. ${ }^{16}$ In a later piece, Geddes adds monarchies to her categorisation of authoritarian regimes. Decision making and power in monarchies is often less concentrated than in other types of authoritarian regimes, as the wider royal family is often involved. ${ }^{17}$ Hadenius and Teorell break Geddes' single-party classification into two: the first of which includes true one-party regimes where no competition is permitted, and the second which focuses on dominant-party regimes where a single party is in power, however competition from opposition parties is allowed. ${ }^{18} \mathrm{~A}$ further type of authoritarian regime is put forward by Chehabib and Linz, who identify sultanism as an extreme form of personalist regime. Sultanistic regimes are characterised by a blurred line between the regime and the state, "a pronounced cult of personality.... [and] a tendency toward dynasticism," constitutional hypocrisy, and a narrow social base. ${ }^{19}$

\footnotetext{
${ }^{14}$ Linz and Stepan, Problems of Democratic Transition and Consolidation: pp. 44-45.

${ }^{15}$ Barbara Geddes, "What do we know about democratisation after twenty years?," Annual Review of Political Science 2(1999): p. 121.

16 Ibid., pp. 121-22.

17 Barbara Geddes, "Changes in the Causes of Democratization Through Time," in The SAGE Handbook of Comparative Politics, ed. Todd Landman and Neil Robinson (SAGE Publications, 2009), p. 292.

18 Axel Hadenius and Jan Teorell, "Pathways from Authoritarianism," Journal of Democracy 18, no. 1 (2007): p. 145.

${ }^{19} \mathrm{H}$. E Chehabi and Juan J. Linz, "A Theory of Sultanism I: A Type of Nondemocratic Rule," in Sultanistic Regimes, ed. H. E Chehabi and Juan J. Linz (Baltimore, MA: The John Hopkins University Press, 1998), pp. 10-19.
} 


\section{Hybrid Regimes}

A further regime type defined in the literature is that of hybrid regimes. An increasing number of scholars encourage those interested in democratisation to look beyond the simple distinction of regime type as either democratic or authoritarian, and consider those hybrid regimes that fill the grey area between. Levitsky and Way are pioneers of this thinking. Concerned that regimes that are neither democratic or authoritarian are perceived as "stalled" or "flawed" transitions, they consider 'competitive authoritarianism' as a regime type in itself, which has the potential to either democratise, become or revert to authoritarianism, or remain stable. ${ }^{20}$ Changes in the international environment following the end of the Cold War, including the end of many super power subsidies, a shifting global balance of power centred around the United States (US), and the emergence of transnational organisations promoting human rights and democracy, have undermined many authoritarian regimes. However, democracy has not always emerged, leading to the proliferation of hybrid regimes which fall somewhere on the spectrum between democracy and authoritarianism. ${ }^{21}$

Levitsky and Way discuss the characteristics that define hybrid regimes. A key point they stress is that in hybrid regimes, electoral competition is the main means by which power is achieved; however the playing field is severely tilted in the favour of a particular group through a variety of measures. ${ }^{22}$ The first characteristic they discuss is that elections are held regularly, however they are often unfree and unfair due to fraud, intimidation of the opposition, and unequal access to the media and resources. Second, in hybrid regimes, civil liberties exist but they are often violated. Third, there exists an uneven political playing field, particularly with regard to resources, media, and the law. Fourth, there is a level of uncertainty in hybrid regimes. Despite the obstacles faced by the opposition during an election campaign, there is still a chance - albeit small - that they will succeed. ${ }^{23}$

Other scholars have also drawn attention to regimes occupying the space between authoritarianism and democracy. In a similar vein to Levitsky and Way, Schedler discusses the notion of "electoral authoritarianism." ${ }^{44}$ Labelling these regimes as "the last line of authoritarian defence," Schedler states that "[i]n their institutional forms, these regimes are virtually indistinguishable from liberal

\footnotetext{
${ }^{20}$ Steven Levitsky and Lucan A. Way, Competitive Authoritarianism: Hybrid Regimes After the Cold War (New York: Cambridge University Press, 2010). p. 4.

21 Ibid., pp. 17-19.

22 Ibid., p. 7.

23 Ibid., pp. 8-12.

${ }^{24}$ Andreas Schedler, ed. Electoral Authoritarianism: The Dynamics of Unfree Competition (Boulder, Colorado: Lynne Rienner Publishers, Inc., 2006).
} 
democracies. Yet authoritarian rulers invariably compensate for these formal concessions with substantive controls." ${ }^{25}$ Building on this notion, Møller and Skanning create a hierarchy of regime types that sit between authoritarianism and democracy, classifying them in terms of 'thinner' and 'thicker' types of democracy. ${ }^{26}$

Levitsky and Way discuss how the trajectory of a hybrid regime is determined by three main factors, including the degree of linkage with the West, the extent of Western leverage, and the organisational power of incumbents. ${ }^{27}$ Linkage with the West refers to the extent to which a regime has ties with the US, the European Union (EU), and multilateral institutions that are dominated by the West. ${ }^{28}$ Linkage can come in a number of forms, including economic, geopolitical, and social ties, as well as connections through communications channels and transnational civil society movements. ${ }^{29}$ The degree of linkage with the West is determined by a number of factors, including history, geostrategic reasons, economic relationships, and, most importantly, geography. ${ }^{30}$ Western linkage can have an impact on a non-democratic regime by raising the cost of authoritarianism in four ways. First, it is likely that heightened linkages with the West will draw attention to a particular government's dictatorial tendencies. Second, this can increase the probability of a response from an international source, or the wider international community. ${ }^{31}$ Third, it can also shape the thinking of domestic actors, "creating domestic constituencies with a stake in adhering to democratic norms." ${ }^{32}$ Finally, linkage with the West can alter the balance of power domestically, strengthening democratic forces in relation to traditional autocrats. ${ }^{33}$

Western leverage refers to a "governments' vulnerability to external democratising pressure." ${ }^{34}$ There are two aspects to this concept, including the degree of a "regimes' bargaining power vis-à-vis the West, or their ability to avoid Western action aimed at punishing abuse or encouraging political liberalisation.... [and] the potential impact (in terms of economic health or security) of Western punitive action toward target states." ${ }^{35}$ Leverage can also increase "the cost of repression, electoral

\footnotetext{
${ }^{25}$ Andreas Schedler, "Authoritarianism's Last Line of Defense," Journal of Democracy 21, no. 1 (2010): pp. 70-71.

${ }^{26}$ Jørgen Møller and Svend-Erik Skaaning, "Regime Types and Democratic Sequencing," Journal of Democracy 24, no. 1 (2013): p. 7.

27 Levitsky and Way, Competitive Authoritarianism: p. 23.

${ }^{28}$ Steven Levitsky and Lucan Way, "International Linkage and Democratization," Journal of Democracy 16, no. 3 (2005): p.

22.

29 Ibid., p. 22-23.

30 Ibid., p. 23.

31 Ibid., pp. 23-24.

32 Ibid., p. 23.

33 Ibid., pp. 23, 25.

34 Ibid., p. 21.

35 Levitsky and Way, Competitive Authoritarianism: pp. 40-41.
} 
fraud, and other government abuses, ${ }^{\prime \prime 6}$ however it is rarely sufficient to encourage reform on its own, and often relies on strong degrees of Western linkage as well.

The organisational power of incumbents is the third factor Levitsky and Way define as being important for determining the trajectory of hybrid regimes. Where organisational power is low, transition can often be easier, however consolidating democracy is difficult. These transitions are referred to as "rotten-door transitions," when the regime can be dismantled easily and often in a spectacular fashion, however lasting institutional change proves more difficult to achieve. ${ }^{37}$ On the other hand, where organisational power is high, transitions are more difficult. When opposition groups succeed in "hard-door transitions" such as these, the new environment is often more conducive to successful democratisation. ${ }^{38}$

The concept of hybrid regime type is particularly useful for this thesis, as Egypt under former President Hosni Mubarak can be considered a hybrid regime. The Mubarak regime allowed for a degree of political participation and did hold elections, albeit highly unfair and fraudulent elections. Mubarak's Egypt also reserved a space for civil society organisations, however they were constantly kept in check so as to ensure they did not gain too much power and pose a threat to the regime. Further details on the nature of the regime under Mubarak will be explicated in Chapter Two. In the post-revolution space, Egypt has once again reverted back to a type of hybrid regime, this time under the auspices of the military and General Abdul Fatah al-Sisi.

\section{Conclusion}

Appreciating the variety of regime types is important for the study of democratisation. The nuances visible across the spectrum of authoritarian regimes have an impact on when and how transitions away from authoritarianism and towards democracy will play out, and there is a vast body of literature that attempts to explain this. Economic theorists focus on development, and situations of economic inequality and crisis. Others consider the role of actors - both elites and those that form civil society - and consider their strengths, weaknesses and allegiances. The idea that international influences have a role to play in when an authoritarian regime will transition considers the concept of the 'contagion' of democracy, as well as the role of democracy promotion efforts by the international community. Theorists who focus on the role of religion and culture claim that some countries are simply destined to remain under authoritarian rule due to their religious or cultural

\footnotetext{
36 Levitsky and Way, "International Linkage and Democratization," p. 22.

37 Levitsky and Way, Competitive Authoritarianism: pp. 354-55.

38 Ibid., p. 356.
} 
disposition. The following chapter will consider the literature surrounding each strand of theory in turn, before focusing on the case of Egypt. 


\section{Chapter One \\ Theories of Democratic Transition: A Literature Review}

\section{Introduction}

There exists a significant body of literature which considers the process of transition away from authoritarianism and towards democracy. In the wake of the Arab Uprisings, there has emerged a steady stream of renewed debate regarding these issues. Despite the encouraging events of 2011, Egypt seems to have remained mired in authoritarianism. Considering the various theories of transition against the Egyptian example can help us to understand why this has occurred, as well as provide the opportunity to critically assess the utility of these theories for explaining contemporary events. The following chapter will provide an overview of four key schools of thought which attempt to explain the process of transition away from authoritarianism and progress towards democratisation. These include, first, theories with a focus on economic conditions, which have been the focus of many in the media and academia in discussions of the Egyptian case. Second, it will consider theories related to the role of elites, civil society and the wider public, as the events in Egypt have displayed an interesting balance of influence from both above and below. Third, ideas relating to external influences and the diffusion of revolution will be discussed. These ideas are particularly pertinent in the Egyptian example, as social media has been lauded as the platform which allowed for the spread of dissent across the region. Finally, this chapter will consider theories based on religious and cultural arguments. Such ideas are particularly relevant in this setting, as the Middle East and indeed Egypt has been described by some as incompatible with democracy.

Before delving into this chapter, one point must be clarified. The end of an authoritarian regime does not necessarily mean the beginning of a transition towards democracy. In fact, the processes of transition away from authoritarianism and towards democracy are entirely separate. In Egypt, we have witnessed the end of Mubarak's authoritarian regime; however a democratic transition has not eventuated. Instead, what we have observed is a reversion to authoritarianism, this time under the auspices of the Egyptian military. 


\section{Economic Factors}

There are three theories which place emphasis on economic factors and their relationship with democratisation: theories which emphasise economic modernisation, theories which consider economic inequality, and those related to economic crisis.

\section{Economic Modernisation}

Modernisation theory links improving levels of economic development to the probability of democratisation. Many scholars have dissected the relationship between economic development and democracy. In his seminal paper Some Social Requisites of Democracy, Lipset explicitly states that "the more well-to-do a nation, the greater the chances that it will sustain democracy." ${ }^{1}$ Lipset goes on to provide evidence for the positive correlation of elements of modernisation, including industrialisation, urbanisation, increasing education levels, and the prospects for democracy. ${ }^{2} \mathrm{~A}$ number of other scholars have written in support of modernisation theory and have linked levels of economic development to the probability of democratisation. In fact, Burkhart and Lewis-Beck label the economic development hypothesis as being so well established that it is almost beyond challenge. ${ }^{3}$ Boix and Stokes argue that the impact of development on democracy is two-fold. Development increases the probability that a transition to democracy will occur, as well as the probability that democracy will endure and sustain itself. ${ }^{4}$ In a later article, Boix discusses changes in social structure brought about by economic development, namely the more equitable distribution of wealth, ${ }^{5}$ and the impact this has on the feasibility of democratic transition. ${ }^{6}$ He states that development brings about "central changes in the distribution and the nature of wealth (and perhaps in the beliefs of actors) thus making democracy a stable political outcome." ${ }^{17}$ Epstein and others also support the modernisation hypothesis, stating that "higher per capita incomes increase the likelihood of a movement away from autocracy as well as decrease the likelihood of a movement away from democracy." 8

\footnotetext{
${ }^{1}$ Seymour Martin Lipset, "Some Social Requisites of Democracy: Economic Development and Political Legitimacy," The American Political Science Review 53, no. 1 (1959): p. 75.

2 Ibid., p. 78.

${ }^{3}$ Ross E. Burkhart and Michael S. Lewis-Beck, "Comparative Democracy: The Economic Development Thesis," The American Political Science Review 88, no. 4 (1994): p. 903.

${ }^{4}$ Carles Boix and Susan C. Stokes, "Endogenous Democratization," World Politics 55, no. 4 (2003): pp. 518-19.

${ }^{5}$ Carles Boix, "Development and Democratization," IBEI Working Papers 26(2009): p. 19.

6 Ibid., p. 22.

$7 \mathrm{lbid}$.

${ }^{8}$ David L. Epstein et al., "Democratic Transitions," American Journal of Political Science 50, no. 3 (2006): p. 552.
} 
A country's level of economic development can impact the move towards democracy in different ways. Over the longer term, positive economic development can create a solid foundation for a democratic regime. Huntington outlines five reasons to support this case. First, the level of economic development of a society correlates strongly with the shape of citizens' "values and attitudes," which in turn correlate with the presence of democracy and democratic institutions. Second, in the same vein as the first, economic development increases education levels within a society. Highly educated people often exhibit the characteristics that go with democracy, including "trust, satisfaction, and competence." Third, economic development encourages the democratic values of accommodation and compromise, as it contributes to a proliferation of resources that are to be distributed throughout society. Fourth, economic development opens up societies to such things as international trade, investment, technology, tourism, and communication, and as a result the democratic ideals held by other countries in the international arena. Fifth, economic development encourages the growth of a middle class. ${ }^{9}$ As Haggard and Kaufman make clear, "the emergence of more complex, literate, middle-class societies ${ }^{\prime 10}$ places pressure on authoritarian regimes, as middle class demands for increased political participation are strong and difficult to ignore, subsequently raising the cost of repression for an authoritarian regime. ${ }^{11}$ On the other hand, rapid economic development over the short term can have a destabilising impact on authoritarian regimes, but this does not always guarantee regime change in the direction of democracy. As Huntington outlines, it can undermine authoritarian regimes and force them to either liberalise, or alternatively to intensify repression. ${ }^{12}$

Welzel and Inglehart echo some of Huntington's ideas. They provide a significant contribution to the literature on political culturalist conceptions of democracy, adding a further dimension to the modernisation debate which emphasises the importance of human agency in discussions surrounding development and democracy. ${ }^{13}$ They claim that "the impact of economic development on democracy works primarily through its tendency to give rise to cultural changes that place increasing emphasis on human emancipation and self-expression." ${ }^{14}$ They pay particular attention to the ability of economic development to reshape public preferences, arguing that it produces pro-

\footnotetext{
${ }^{9}$ Samuel P. Huntington, The Third Wave: Democratization in the Late Twentieth Century, vol. 4 (Norman: University of Oklahoma Press, 1993). pp. 65-66.

10 Stephan Haggard and Robert R. Kaufman, The Political Economy of Democratic Transitions (Princeton, N.J: Princeton University Press, 1995). p. 25.

11 Juan J. Linz and Alfred Stepan, Problems of Democratic Transition and Consolidation: Southern Europe, South America, and Post-Communist Europe (Baltimore, MA: The John Hopkins University Press, 1996). p. 78.

12 Huntington, The Third Wave, 4: p. 59.

${ }^{13}$ Christian Welzel and Ronald Inglehart, "Democratization as the Growth of Freedom: The Human Development Perspective," Japanese Journal of Political Science 6, no. 03 (2006): p. 315.

${ }^{14}$ Christian Welzel and Ronald Inglehart, "Liberalism, Postmaterialism, and the Growth of Freedom," International Review of Sociology 15, no. 1 (2005): p. 84.
} 
democracy "mass liberty aspirations,"15 and subsequently growing pressure for political freedom. Welzel and Inglehart conclude by noting that mass liberty aspirations both encourage the development of democracy in autocratic settings, as well as promote its survival in established democracies. ${ }^{16}$

Przeworski and Limongi criticise modernisation theory and the linking of economic development and democracy. They argue that the endogenous explanation linking economic development to the emergence of democracy does not hold. Przeworski and Limongi are critical of the passive nature of modernisation theory. They state that in "modernisation theory no one does anything to bring democracy about; it is secreted by economic development and the corollary social transformations.... [D]emocratisation [is] an outcome of actions, not just of conditions." ${ }^{17}$ They stress the key role political actors have to play in bringing about democratisation; it is not simply "a byproduct of economic development." ${ }^{18}$ In their seminal book Democracy and Development, Przeworski and others take their question of whether economic development is conducive to political democracy much further, considering a variety of case studies and providing an impressive level of statistical analysis. ${ }^{19}$ Here they explicitly state that "modernisation theory appears to have little, if any, explanatory power."20 Kennedy also questions the arguments put forward by modernisation theorists, stating that the theory is inherently contradictory. ${ }^{21}$ He argues that economic development instead decreases the probability that institutional change will occur, and tends to increase the stability of authoritarian regimes. However, he concedes that when institutional changes do take place at higher levels of economic development, there is an increased probability that these changes will involve a movement towards democracy. ${ }^{22}$ Przeworki and Limongi also support the exogenous explanation that links economic development to the survival of existing democracies. In an earlier paper, Przeworski and others explicitly state that "once a country is sufficiently wealthy, with per capita income of more than $\$ 6000$ a year, democracy is certain to survive, come hell or high water."23 Bunce also supports the exogenous explanation of

\footnotetext{
15 Ibid., p. 87.

16 Ibid., p. 102.

17 Adam Przeworski and Fernando Limongi, "Modernization: Theories and Facts," World Politics 49, no. 2 (1997): p. 176.

18 Ibid., p. 177.

${ }^{19}$ Adam Przeworski et al., Democracy and Development: Political Institutions and Well-Being in the World, 1950 - 1990

(Cambridge: Cambridge University Press, 2000).

20 Ibid., p. 137.

${ }^{21}$ Ryan Kennedy, "The Contradiction of Modernization: A Conditional Model of Endogenous Democratization," The Journal of Politics 72, no. 03 (2010): p. 789.

22 Ibid., p. 785

${ }^{23}$ Adam Przeworski et al., "What Makes Democracies Endure?," Journal of Democracy 7, no. 1 (1996): p. 48.
} 
democratisation, arguing that the "level of economic development seems to have considerable impact not so much on whether democracy exists... as on its sustainability over time." ${ }^{24}$

\section{Economic Inequality}

A further strand of theory looks at economic inequality and its relationship with democratisation. Boix is amongst the group of scholars who argue that unequal societies are less likely to experience democratisation. He states that "[a]s the distribution of assets and income becomes more balanced among individuals, the redistributive impact of democracy diminishes and the probability of a peaceful transition from an authoritarian regime to universal suffrage increases." ${ }^{25}$ Acemoglu and Robinson also argue that democratisation is unlikely to occur where very high levels of inequality exist, as elites will feel so threatened by the prospect of democracy that they may intensify repression in order to avoid it. ${ }^{26}$ However, Acemoglu and Robinson do not expect that very equal societies will even experience democratisation in the first place. This is because equality means the "political status quo" will remain stable, regardless of how nondemocratic a regime may be. ${ }^{27}$ Instead, there needs to be some level of inequality for democratisation to occur. However, this inequality does not create a fertile environment for democracy to grow, as democratic consolidation requires higher levels of economic equality. ${ }^{28}$

A number of scholars take an opposing view, arguing that economic inequality has no significant impact on a country's prospects for democratisation. Houle argues against the arguments put forward by Boix and Acemoglu and Robinson, explicitly stating that "inequality... has no net effect on democratisation." ${ }^{29}$ Houle claims that there are three issues with the theories linking inequality to democratisation. First, they have more utility when explaining transitions from below, ignoring those transitions instigated from above by elites. ${ }^{30}$ Second, using inequality to explain transitions results in ambiguity. As Houle outlines, "inequality makes democracy more costly for the elites by increasing redistribution, thus diminishing the probability of democratisation. On the other hand, inequality increases the population's demand for regime change by increasing potential gains from

\footnotetext{
${ }^{24}$ Valerie Bunce, "Comparative Democratization: Big and Bounded Generalizations," Comparative Political Studies 33, no. 6-7 (2000): p. 706.

${ }^{25}$ Carles Boix, Democracy and Redistribution (Cambridge: Cambridge University Press, 2003). p. 3.

${ }^{26}$ Daron Acemoglu and James A. Robinson, Economic Origins of Dictatorship and Democracy (Cambridge: Cambridge University Press, 2006). p. 1.

$27 \mathrm{lbid}$.

28 Ibid., p. 38.

${ }^{29}$ Christian Houle, "Inequality and Democracy: Why Inequality Harms Consolidation but Does Not Affect Democratization," World Politics 61, no. 04 (2009): p. 590.

30 Ibid., p. 593.
} 
redistribution or expropriation, thus increasing the probability of democratisation." ${ }^{31}$ Third, the theories that link inequality and democratisation overlook the issues associated with collective action, including the imbalanced cost benefit calculation participants face, and the fact that the benefits of revolution are extended to everyone, decreasing incentives to participate. ${ }^{32}$ Elites will therefore have very little incentive to democratise if the population is unable or unwilling to rise up.

\section{Economic Crisis}

A further strand of theory linking economic factors and democratisation focuses on the potential of economic crisis to destabilise authoritarian regimes. Haggard and Kaufman define economic crises as being "characterised by a sharp deterioration in aggregate economic performance, indicated by slowed growth and accelerated inflation. ${ }^{\prime 33}$ In order to tackle economic crises, policy adjustment or change is required. Regimes that fail to deal with deteriorating economic circumstances, regardless of whether they are authoritarian or not, will find themselves in an increasingly unstable position. However, authoritarian regimes are likely to be affected to a greater degree than their democratic counterparts. Linz and Stepan discuss the reason for this, namely that authoritarian regimes "are often heavily dependent on their performance claims but are not bolstered by procedural claims deriving from their democratic status." ${ }^{34}$ This is in contrast with democratic regimes, which have "two valuable sources of insulation from sustained economic downturn not available to a nondemocratic regime: its claim to legitimacy based on its origin and the fact that elections are always on the horizon and hold the prospect of producing an alternative socioeconomic program and an alternative government without regime change." ${ }^{\prime 35}$

This concept is linked closely with the idea that political effectiveness and legitimacy are crucial prerequisites for the development of democracy in any setting. Lipset, a key proponent of this idea, defines effectiveness in terms of the performance of a political system, which is "marked by an efficient bureaucracy and decision-making system.." ${ }^{36}$ Legitimacy builds on the notion of effectiveness in the sense that it is determined by the endurance of effectiveness. Legitimacy "involves the capacity of a political system to engender and maintain the belief that existing political institutions are the most appropriate or proper ones for the society." ${ }^{37}$ In a later paper, Lipset makes it clear that authoritarian regimes are more often than not lacking in both effectiveness and

\footnotetext{
$31 \mathrm{lbid}$.

32 Ibid., p. 595.

${ }^{33}$ Haggard and Kaufman, The Political Economy of Democratic Transitions: p. 8.

${ }^{34}$ Linz and Stepan, Problems of Democratic Transition and Consolidation: p. 79.

$35 \mathrm{lbid}$.

${ }^{36}$ Lipset, "Some Social Requisites of Democracy," p. 86.

$37 \mathrm{lbid}$.
} 
legitimacy, and public resentment and rejection is therefore likely to be high. As a result, authoritarian regimes are more likely to be unable to cope in a crisis situation, and regime collapse is likely. ${ }^{38}$ Adding to the literature, Acemoglu and Robinson link regime change with periods of recession. They argue that during economic downturns, the "costs of political turmoil, both to the rich and to the poor, are lower." ${ }^{39}$ Przeworski et al. again provide an influential counter argument to claims regarding economic crisis. They state that dictatorships are, in fact, less sensitive to the destabilising effect of economic crises, and provide statistical evidence to support this. ${ }^{40}$

\section{Conclusion}

Theories linking modernisation, levels of economic inequality, and economic crisis to the prospects of democracy are prevalent throughout the literature on democratisation, and make up an influential part of the wider body of literature. The Egyptian Revolution has been linked to economic explanations, particularly that of inequality, on numerous occasions by both the media and academics. However, there are questions surrounding the degree to which the Egyptian case supports these theories. I will return to consider the case of Egypt alongside these ideas in later chapters.

\section{The Influence of Elites and Civil Society}

The influence of regime elites and civil society, as well as the relationship between the two, is widely discussed in the democratisation literature. There are two models that focus on the influences of actors on transitions: one which focuses on elite-led transitions, the other on grassroots transitions originating amongst civil society and the wider public.

\section{Elite-led Model}

This model of democratisation focuses largely on the role of elites and portrays transition in a controlled and negotiated manner. O'Donnell and Schmitter provide a seminal contribution to this scholarship, structuring their argument around an analysis of 'hard-liners' and 'soft-liners,' arguing that the cleavage between the two within an existing authoritarian regime lies at the root of all transitions. ${ }^{41}$ It is this cleavage that creates a space which allows for the emergence of civil society.

\footnotetext{
${ }^{38}$ Seymour Martin Lipset, "The Social Requisites of Democracy Revisited," American Sociological Review 59(1994): p. 9. 39 Daron Acemoglu and James A. Robinson, "A Theory of Political Transitions," The American Economic Review 91, no. 4 (2001): p. 939.

40 Przeworski et al., Democracy and the Market: p. 109.

${ }^{41}$ Guillermo O'Donnell and Philippe C. Schmitter, Transitions from Authoritarian Rule: Tentative Conclusions about Uncertain Democracies (Baltimore, Maryland: The John Hopkins University Press, 1986). p. 19.
} 
However, they see the role of civil society as being relatively short lived, and typically a reversion to a form of "depoliticised citizenship" 42 will occur.

O'Donnell and Schmitter then introduce their idea of 'pacts' and the role these have to play in the democratisation process. They define a pact as an "explicit, but not always publicly explicated or justified, agreement among a select set of actors which seeks to define (or, better, to redefine) rules governing the exercise of power on the basis of mutual guarantees for the "vital interests" of those entering into it." ${ }^{\prime 3}$ Pacts involve a somewhat cautious negotiation among elites regarding the direction of transition, some of whom are looking to uphold the old authoritarian order. As they are elite negotiations, pacts tend to "move the polity towards democracy by undemocratic means," discussion and decision making is often restricted to high-level settings. Pacts are often devised as temporary measures, however they do have the potential to become institutionalised and an integral part of the post-transition regime. O'Donnell and Schmitter make it clear that pacts are not a feature of all transitions, as in some cases representatives of the old order may not have the authority to be involved in making decisions on the nature of the new regime. However, O'Donnell and Schmitter are of the opinion that pacts are positive features of transitions, enhancing "the probability that the process will lead to a viable political democracy." ${ }^{\prime 4}$

Other scholars have also focused on the controlled, elite-led aspect of transitions. Huntington proposes three possible variations of democratisation that have a focus on the role of elite actors. The first he terms transformation, where a leading role in regime change is assumed by powerful reformers within the authoritarian regime. ${ }^{46}$ These elites are similar to O'Donnell and Schmitter's 'soft-liners.' The second possibility for democratisation is that it occurs through replacement. Here democratisation relies on the strength of the opposition and their ability to overthrow the existing regime. Huntington emphasises the difficulty inherent in the three phases of replacement, which he states are "the struggle to produce the fall, the fall, and the struggle after the fall." 47 Democratisation through replacement involves the erosion of support for the authoritarian regime, which can occur either overtly or covertly. ${ }^{48}$ Huntington terms the third process transplacement, which involves the government and opposition working together to bring about regime change. This

\footnotetext{
42 Ibid., p. 26.

43 Ibid., p. 37.

44 Ibid., p. 38.

45 Ibid., p. 39.

46 Huntington, The Third Wave, 4: p. 124.

${ }^{47}$ Ibid., p. 142.

48 Ibid., p. 144.
} 
is made possible when a balance between regime standpatters and reformers is reached, and the regime is willing to negotiate a change in the political status quo, but not go as far as to initiate it. ${ }^{49}$

Przeworski also contributes to the literature on elite-led regime change, suggesting a framework based on O'Donnell and Schmitter's earlier work which involves two aspects of democratisation: extrication from the old authoritarian regime, and the constitution of a democratic one. ${ }^{50} \mathrm{He}$ considers the involvement of four key political actors involved in the democratisation process: Hardliners and Reformers, part of the old authoritarian order, and Moderates and Radicals, who are the opposition. Przeworski proposes that democratisation is only possible if negotiations among the four parties provide each group with the opportunity to balance their conflicting interests. Moderates and Radicals in the opposition often have to be pragmatic and make concessions to the Hardliners and Reformers. However, as Przeworski makes clear, "the conditions created by transition negotiated with the ancient regime are not irreversible." ${ }^{51}$ In fact, one of the key tenets of democracy is that the people and opposition factions are able to change the direction of the state through regular elections.

On a note related to elite-led regime change, ideas surrounding the role of the military apparatus in the process of democratisation are particularly useful in the context of this thesis. Barany provides an excellent contribution to the literature, arguing that a push for democratisation is most likely to fail if the military remains loyal to the authoritarian regime..$^{52}$ He argues that there are four influences on militaries and the course of action they may take during revolutionary periods. First, the influence of the military establishment itself, including its degree of cohesion and general composition..$^{53}$ Second, influences from the state are important, including how the military is treated and perceived by the state, and what directions the military receives from the state during periods of revolution. ${ }^{54}$ Third, society at large has an influential role on how the military acts. The nature of the uprising - who is involved, how popular it is, and the nature of the demonstrations, including whether they are violent or not - will significantly impact how the military decides to react. ${ }^{55}$ Finally, international influences also have a role to play in forming the military's course of action, particularly the potential of foreign intervention and "revolutionary diffusion." ${ }^{56}$ Nepstad echoes a number of

\footnotetext{
49 Ibid., p. 151.

${ }^{50}$ Adam Przeworski, Democracy and the Market: Political and Economic Reforms in Eastern Europe and Latin America (New York: Cambridge University Press, 1991). p. 67.

51 Ibid., p. 79.

52 Zoltan Barany, "Armies and Revolutions," Journal of Democracy 24, no. 2 (2013): p. 62.

53 Ibid., p. 63.

54 Ibid., pp. 68-69.

55 Ibid., pp. 70-72.

56 Ibid., pp. 72-73.
} 
these points, arguing that whether or not a military defects from a particular regime at a point of transition depends on two factors: whether the military receives either political or economic benefits from the regime, and the military's perception of the regime's fragility, which is dependent on international stances towards the regime..$^{57}$

\section{Civil Society Model}

These models of elite-led transition outlined above make very little mention of the role played by civil society and the general population in bringing about regime change. An opposing model of democratisation considers the process from below, with a focus on the role played by civil society and the mass public. Diamond defines civil society as "the realm of organised social life that is open, voluntary, self-generating, at least partially self-supporting, autonomous from the state, and bound by a legal order or set of shared rules." ${ }^{58}$ He goes on to state that "[t]he mass public matters for democratisation in two senses: in its often pivotal role (too little appreciated by the scholarly literature) in helping to effect a transition to democracy, and in the never-ending quest to deepen democracy beyond its formal structure. ${ }^{\prime 59}$ Levine echoes this, making it clear that the process of democratisation is not solely an elite creation, despite often being portrayed that way in the literature. He states:

Average people are excluded from this analysis, as if they had not been involved all along; they simply remain in the wings, waiting for the transition to be complete. But this will not do. It divorces the process from those involved. ${ }^{60}$

The existence of a strong civil society plays an important role in the destabilisation of authoritarian regimes, as it provides a forum for action and the expression of dissent. In the model proposed by O'Donnell and Schmitter outlined earlier, civil society emerges from the space created by elites. However, in many cases civil society emerges prior to regime disintegration, either through civil upsurge and revolution, or the more covert growth of pluralism and autonomy throughout sectors of society. ${ }^{61}$

As mentioned previously, O'Donnell and Schmitter argue that once an authoritarian regime has been toppled, civil society becomes fatigued and largely withdraws from sight. ${ }^{62}$ They go on to discuss that

\footnotetext{
57 Sharon Erickson Nepstad, "Mutiny and nonviolence in the Arab Spring: Exploring military defections and loyalty in Egypt, Bahrain, and Syria," Journal of Peace Research 50, no. 4 (2013): p. 337.

58 Larry Diamond, Developing Democracy: Toward Consolidation (Baltimore, Maryland: The John Hopkins University Press, 1999). p. 221.

59 Ibid., p. 219.

60 Daniel H. Levine, "Paradigm Lost: Dependence to Democracy," World Politics 40, no. 3 (1988): p. 385.

${ }^{61}$ Diamond, Developing Democracy: p. 234.

62 O'Donnell and Schmitter, Transitions from Authoritarian Rule: p. 55.
} 
a highly mobilised civil society may in fact hinder democratic consolidation, hinting that there is diminished space for civil society to exist alongside political society. ${ }^{63}$ However, Linz and Stepan argue the opposite, advocating for the importance of civil society's involvement at all stages of the democratisation process and beyond. They state that "[a] robust civil society, with the capacity to generate political alternatives and to monitor government and state can help transitions get started, help resist reversals, help push transitions to their completion, help consolidate, and help deepen democracy. ${ }^{164}$ Diamond echoes this, proposing that civil society has a number of key roles to play to assist in deepening democracy once it is achieved. These include monitoring state power and corruption, encouraging political participation, providing a forum for the expression of citizen interests beyond the political party, and enhancing the regime's legitimacy, in turn garnering respect for the state. ${ }^{65}$ In a more recent paper, Schmitter takes a look back at the intervening years since he edited the Transitions series with O'Donnell. He asserts that civil society has, in fact, played a significant role on a number of occasions, however this role can be "ambiguous or even malign." ${ }^{66}$

\section{Influences from Elites and Civil Society}

Other scholars take a middle road, arguing that the process of democratisation involves both elites and civil society, and both are of equal importance. Collier, for example, argues that "[i]n most cases the politics of democratisation is a combination of processes from above and below, involving combinations of class interests, strategic actors, and forms, sites, or arenas of action." ${ }^{67}$ Przeworski recognises this view, conceding that the focus on top-down and bottom-up models of democratisation can sometimes prove overly simplistic. Instead, democratisation can be influenced by both "elements from above and from below." ${ }^{68}$ Despite their focus on the role of elites, O'Donnell and Schmitter do create a space for civil society in the transition process. However, the role of civil society is dependent on the position of elites and the extent to which they control the transition. ${ }^{69}$ Also, they argue that the wave of civil society involvement "crests sooner or later.... A certain normality is subsequently reasserted as some individuals and groups depoliticise themselves again, having run out of resources or become disillusioned." ${ }^{70}$ Nevertheless, MacEwan criticises O'Donnell and Schmitter's lack of focus on popular classes during the transition process, ${ }^{71}$ as does Levine, who

\footnotetext{
63 Ibid., p. 65.

64 Linz and Stepan, Problems of Democratic Transition and Consolidation: p. 7.

65 Diamond, Developing Democracy: pp. 239-49.

66 Philippe C. Schmitter, "Twenty-Five Years, Fifteen Findings," Journal of Democracy 21, no. 1 (2010): p. 24.

${ }^{67}$ Ruth Berins Collier, Paths Toward Democracy: The Working Class and Elites in Western Europe and South America (Cambridge: Cambridge University Press, 1999). p. 20.

68 Przeworski, Democracy and the Market: p. 56.

69 O'Donnell and Schmitter, Transitions from Authoritarian Rule: pp. 53-55.

70 Ibid., p. 26.

${ }^{71}$ Arthur MacEwan, "Review "Transitions from Authoritarian Rule"," Latin American Perspectives 15, no. 3 (1988): p. 121.
} 
argues that it is in fact the popular groups in society that grant elites the legitimacy to enter into pacts. $^{72}$

\section{Conclusion}

Theories focusing on the influences of both elites and civil society are widespread throughout the literature on transitions and democratisation. The Egyptian case does not exclusively support one of these two models. Instead, we can see influences stemming from both above and below. As I will discuss in later chapters, the position assumed by the Egyptian military elites played a pivotal role in shaping the events that transpired in Egypt, as did the mobilisation of people at a grassroots level.

\section{The Policies of External Actors and Process of Diffusion}

The policies of external actors and diffusion of democratic ideas can contribute to the erosion of authoritarian regimes. Scholars, such as Gleditsch and Ward, place significant weight on these concepts, arguing that "international factors influence the prospects for democracy, and... transitions are not simply random but are more likely in the wake of changes in the external environment."73 External actors have influenced transitions to democracy in the past. In the case of the Southern European transitions, the EU encouraged regime transformation while at the same time promoting membership. The US has also been particularly vocal in their promotion of democracy and human rights throughout the world. ${ }^{74}$ Diamond considers this as the first of his five models of diffusion. His second model considers the role played by non-governmental organisations (NGOs) in encouraging and assisting the development of democracy in other countries. ${ }^{75}$

The third model Diamond outlines is known as the "demonstration effect," which involves the imitation of, and political learning from, past transitions. ${ }^{76}$ Numerous other scholars have discussed this idea, which involves communities considering previous events and, where they are able to recognise elements that appear relevant to their situation, "often consciously or unconsciously attempt to adjust their behaviour so as to achieve or avoid a comparable outcome." ${ }^{177}$ Bessinger discusses "modular political phenomena" related to regime change, where actions are "based in

\footnotetext{
72 Levine, "Paradigm Lost," p. 379.

${ }^{73}$ Kristian Skrede Gleditsch and Michael D. Ward, "Diffusion and the International Context of Democratisation," International Organization 60, no. 4 (2006): p. 912.

74 Huntington, The Third Wave, 4: p. 85.

75 Diamond, Developing Democracy: p. 56.

76 Ibid., p. 57.

77 Linz and Stepan, Problems of Democratic Transition and Consolidation: p. 76.
} 
significant part on emulation of the prior successful example of others." ${ }^{178}$ Bessinger outlines five basic features shared by all modular political phenomena. First, "the sense of interconnectedness across cases produced by common institutional characteristics, histories, cultural affinities, or modes of domination"79 underpins modular phenomena and allows communities to see links between their situation and that of others. Second, modular phenomena are spread at a basic level by emulation, particularly in situations of geographic proximity. ${ }^{80}$ Third, the "weight of example in affecting behaviour across cases follows the pattern of a tipping model," ${ }^{81}$ whereby examples become gradually more influential with each success, however eventually reach a point where this influence begins to decline. Fourth, modular behaviour involves more than simply "the pull of example; it is also in part a matter of the push of mutual empowerment." 82 It involves the promotion of change by those who have already experienced it through, for example, the sharing of knowledge and encouragement. Fifth, "the spread of modular action is not a random process, but is shaped across space and time by certain pre-existing structural conditions." ${ }^{13}$ It is concepts such as these which complement Huntington's 'wave' analogy, a seminal contribution to the democratisation literature. Huntington defines a wave of democratisation as "a group of transitions from nondemocratic to democratic regimes that occur within a specific period of time and that significantly outnumber transitions in the opposite direction." ${ }^{84}$ Such waves may not necessarily result in democratisation, however they can be instigated by the demonstration effect. ${ }^{85}$

Returning to Diamond's five models, the fourth model of diffusion he proposes is normative in nature. He argues that regime change can come about with a shift in ideas about "what is intrinsically good, right, and desirable." ${ }^{86}$ This model involves a gradual process, characterised by a shifting consciousness over time as a result of increased contact with other countries and cultures. This contact has become particularly heightened in recent years due to increased trade, channels of communication, and travel. ${ }^{87}$ The final model Diamond discusses is characterised by "the general trend toward global standardisation, or isomorphism, in the structure of states." ${ }^{88}$ Building on the previous four models, this model of diffusion focuses on the similarities in state structure across a

\footnotetext{
78 Mark R. Beissinger, "Structure and Example in Modular Political Phenomena: The Diffusion of Bulldozer/Rose/Orange/Tulip Revolutions," Perspectives on Politics 5, no. 02 (2007): p. 259.

79 Ibid., p. 263.

80 Ibid., pp. 264-65.

81 Ibid., p. 265.

82 Ibid., p. 266.

$83 \mathrm{lbid}$.

84 Samuel P. Huntington, "Democracy's Third Wave," Journal of Democracy 2, no. 2 (1991): p. 15.

85 Ibid., p. 100.

86 Diamond, Developing Democracy: p. 57.

87 Ibid., p. 58.

$88 \mathrm{lbid}$.
} 
variety of sectors, including the economy, education, health, and welfare. Diamond argues that the emergence of similar structures in spatially diverse settings means that transnational factors can have an influence. This influence can spill over into the realm of state power, which is becoming increasingly defined globally as being "selected through regular, competitive, multiparty elections with universal franchise." ${ }^{89}$

Despite the euphoric tone that underlies much of the literature on democratic diffusion and the power of example, ${ }^{90}$ Bessinger points out that caution is warranted. Prior example has a significant effect on the behaviour of others, however there are often "unintended side effects of modular change, ${ }^{\prime \prime 1}$ particularly in situations that perhaps do not possess the same conditions conducive to success as those whose example is being followed. In cases such as this, violence and civil war are often a result. This can alter the political landscape, in some instances even leading to increased repression from the authoritarian regime. ${ }^{92}$ Also, modular change has implications for the democratic transition period and beyond. Often countries following by example have not yet developed the structural conditions required for the consolidation of a stable democracy, leading to "outcomes that are less robust and less stable than might be expected under conditions of the complete independence of cases." ${ }^{93}$

Weyland, in his discussion of the 'diffusion of revolution,' also draws attention to some of the potential issues associated with ideas of diffusion. He highlights the role played by 'cognitive heuristics,' where actors "deviate from fully rational procedures [drawing] attention to some experiences but not others and [induce] both challengers and defenders of the established order to draw rash conclusions from these experiences." ${ }^{\prime 4}$ In a more recent article, Weyland argues that emulative protesters in the 1848 Europeans revolutions and the recent Arab Uprisings did not make rational calculations, and made decisions based on "cognitive shortcuts" due to pronounced "conditions of profound uncertainty, when established norms and institutions lose their guiding force, people face unexpected novelty, and outcomes seem up for grabs." ${ }^{\prime 95}$ Weyland argues that this contributed to the shattering of initial hopes and limited successes of both the revolutions of the

$89 \mathrm{lbid}$.

90 See, for example: J. L. Gelvin, The Arab Uprisings: What Everyone Needs to Know (New York: Oxford University Press, 2012); Marc F. Plattner, "The Global Context," Journal of Democracy 22, no. 4 (2011); Lucan Way, "Comparing the Arab Revolts: The Lessons of 1989," Journal of Democracy 22, no. 4 (2011).

91 Beissinger, "Structure and Example in Modular Political Phenomena," p. 273.

$92 \mathrm{lbid}$.

93 Ibid., p. 274.

${ }^{94}$ Kurt Weyland, "The Diffusion of Revolution: '1848' in Europe and Latin America," International Organization 63, no. 03 (2009): p. 391.

${ }^{95}$ Kurt Weyland, "The Arab Spring: Why the Surprising Similarities with the Revolutionary Wave of 1848?," Perspectives on Politics 10, no. 04 (2012): p. 921. 
$19^{\text {th }}$ century and more recently in $2011 .^{96}$ On a similar note, Hale considers 'regime change cascades,' arguing that "although protest cascades in the name of democracy are a widespread phenomenon, transnational cascading dynamics were less likely to be decisive in causing a revolution and quite unlikely to bring about actual regime change in a democratising direction." ${ }^{97}$ In fact, he points out that cascades towards hybrid regimes are a more likely occurrence. ${ }^{98}$

Despite compelling arguments from a number of scholars regarding the influences of external actors and the diffusion of democracy, others argue that the process of democratisation is largely internal. In their seminal work, O'Donnell and Schmitter make it clear that the actors involved in, and influences on, transitions to democracy stem from a national level. They state that "there is no transition whose beginning is not the consequence - direct or indirect - of important divisions within the authoritarian regime itself," 99 specifically between regime hard-liners and soft-liners, a distinction which I discussed earlier in this chapter. However, in a later paper, Schmitter discusses how the wider international context has come to have a more significant role in determining "both the timing and the mode of transition, as well as its outcome." ${ }^{100}$ He cites two reasons for this: first, the plethora of international organisations which have formed promoting democracy and human rights; and second, the EU's focus on democratisation, encouraged using the carrot of membership. Linz and Stepan also assent that international influences do have a part to play during the transition phase, however whether or not democracy is able to be consolidated is determined more so by the domestic climate than by the foreign policies of others. ${ }^{101}$

\section{Conclusion}

A consideration of past transitions reveals that both external and internal factors have had a role to play, and the Egyptian case echoes this. The idea of democratic diffusion has been widely cited in the emerging literature on the Egyptian Revolution and the Arab Uprisings, and we can clearly observe the spread of contentious politics from Tunisia into Egypt and further afield, with assistance from social media and other technologies. The Egyptian case strongly supports theories related to diffusion, and also those relating to international democracy promotion efforts, albeit to a somewhat lesser degree. I will return to look at these factors in more detail in later chapters.

\footnotetext{
96 Ibid., p. 928.

97 Henry E. Hale, "Regime Change Cascades: What We Have Learned from the 1848 Revolutions to the 2011 Arab Uprisings," Annual Review of Political Science 16, no. 1 (2013): p. 2.

98 Ibid., p. 19.

99 O'Donnell and Schmitter, Transitions from Authoritarian Rule: p. 19.

${ }^{100}$ Schmitter, "Twenty-Five Years, Fifteen Findings," p. 27.

101 Linz and Stepan, Problems of Democratic Transition and Consolidation: p. 73.
} 


\section{Religious and Cultural Arguments}

Arguments linking religion and culture to regime type and prospects for democracy are apparent throughout the literature. In his book The Third Wave, Huntington considers the "strong correlation" between Western Christianity and democracy. Western Christianity's emphasis on individual dignity and secularism means it "seems plausible to hypothesise that the expansion of Christianity encourages democratic development." ${ }^{102}$ However, he caveats his argument by making it clear that this is not always necessarily the case. Huntington states that "the world's great historic cultural traditions vary significantly in the extent to which their attitudes, values, beliefs, and related behaviour patterns are conducive to the development of democracy." ${ }^{103}$ He names Confucianism and Islam as the two cultures that are considered in the literature as being particularly hostile towards democracy. Fish also reflects on the 'democratic deficit' that is apparent across Islamic countries. He hypothesises that "Muslim countries are democratic underachievers," and concludes that the subordinate position of women across the spectrum of society in Islamic countries is the reason for this. ${ }^{104}$ However, as Huntington makes clear, arguments based on religion and culture are problematic. He states: "Any major culture, including even Confucianism, has some elements that are compatible with democracy, just as both Protestantism and Catholicism have elements that are clearly undemocratic." ${ }^{\prime 05}$ Also, he makes it clear that the dynamic nature of culture means that societal attitudes, and hence societal approaches towards democracy, have the ability to change. ${ }^{106}$

Diamond also discusses culturalist ideas and the 'Arab democracy deficit.' He rules out the common assumption that the lack of democratic regimes in the Middle East has something to do with religion or culture. ${ }^{107}$ Instead, he argues that the democracy deficit in the Middle East can be explained by structural reasons, including levels of economic development and the so-called 'resource curse,'108 and the nature of authoritarianism in the region. He also considers geopolitical factors which serve to "reinforce the internal hegemony of Arab autocracies," including foreign support for longstanding authoritarian regimes, the Arab-Israeli conflict, and the tradition of authoritarian leaders across the region supporting each other, largely through the Arab League. ${ }^{109}$ Bellin takes a similar stand, arguing that rather than lacking the cultural prerequisites for democracy, the Middle East is instead characterised by conditions that sustain authoritarianism and foster "a robust and politically

\footnotetext{
102 Huntington, The Third Wave, 4: p. 73.

103 Ibid., p. 298.

104 M. Steven Fish, "Islam and Authoritarianism," World Politics 55, no. 01 (2011): pp. 4-5.

105 Huntington, The Third Wave, 4: p. 310.

106 Ibid., p. 311.

107 Larry Diamond, "Why Are There No Arab Democracies?," Journal of Democracy 21, no. 1 (2010): p. 94.

${ }_{108}$ Michael L. Ross, "Does Oil Hinder Democracy?," World Politics 53, no. 3 (2001). Michael L. Ross, "Will Oil Drown the Arab Spring? Democracy and the Resource Curse," Foreign Affairs 90, no. 5 (2011).

109 Diamond, "Why Are There No Arab Democracies?," pp. 97-101.
} 
tenacious coercive apparatus." ${ }^{110}$ These factors include rentierism, international support, the prevalence of patrimonialism, a weak popular sector, and the existence of a credible threat from Israel.

\section{Conclusion}

Arguments related to religion and culture appear somewhat dated alongside other theories that make up the literature on democratisation, living up to the patronising nature of some Western academia, identified by academics such as Edward Said in Orientalism. ${ }^{111}$ The Egyptian case does not lend support to theories related to religion and culture. Studies such as the Arab Barometer and the World Values Survey clearly show significant support for democracy and a desire to achieve democratic rule. I will return to consider these ideas later in this thesis.

\section{Conclusion}

After dealing with the variety of theories that attempt to explain transitions away from authoritarianism and the processes behind democratisation, it must be noted that dealing with prerequisites for authoritarian collapse and democratic transition can be problematic. None of the theories discussed in this chapter provide a sufficient explanation for the collapse of authoritarianism or development of democracy. As Huntington makes clear, democratisation movements are the result of a combination of causes, and these can vary considerably between cases and 'waves.' ${ }^{112}$ It also must be clarified that democracy is not necessarily the outcome of regime change and periods of transition. Instead, transitions away from authoritarianism are highly likely to move in the direction of "an uncertain "something else","113 or even a reversion to authoritarianism.

In the following two chapters, I will cover the history of modern authoritarianism in Egypt from 1952 to 2011, followed by an outline of the Egyptian Revolution and its aftermath. I will then return to discuss in turn each of the four strands of theory outlined in this chapter alongside the case of Egypt. This analysis will provide an understanding of which bodies of theory garner support from the Egyptian case, and which are less robust, as well as uncover why Egypt has not made progress towards democracy.

${ }^{110}$ Eva Bellin, "The Robustness of Authoritarianism in the Middle East: Exceptionalism in Comparative Perspective," Comparative Politics 36, no. 2 (2004): p. 152.

111 Edward W. Said, Orientalism (London: Routledge and Kegan Paul Ltd., 1978).

112 Huntington, The Third Wave, 4: p. 38.

113 O'Donnell and Schmitter, Transitions from Authoritarian Rule: p. ix. 


\section{Chapter Two \\ A History of Modern Authoritarianism in Egypt $1952-2011$}

\section{Introduction}

An understanding of history is important for setting the scene and enabling a deeper comprehension of more recent events in Egypt. This chapter will focus on the modern history of authoritarian rule in Egypt, beginning with the 1952 Free Officers Revolution, and culminating with the uprising of 2011. Modern authoritarian rule in Egypt can be divided into three periods under three different presidents - Nasser, Sadat, and Mubarak - around which this chapter will be structured. It will consider the various political arrangements and economic policies in place under each president, as well as the nature of civil society. The years 1952 and 2011 provide appropriate bookends for this chapter, as these years both saw revolution in Egypt. Prior to 1952, Egypt was a monarchy, and therefore characterised by different dynamics than it was following the birth of the Egyptian Republic. Both the Sadat and Mubarak regimes were natural leadership changes, in terms of the vice president stepping in to fill the role of president. Each regime also inherited a legacy, which has proved important in shaping Egypt's history, and our subsequent understanding of the 2011 revolution. Some common themes emerge when considering the history of modern authoritarianism in Egypt over the three periods, such as the persistence of military influence and electoral authoritarianism, a tradition of state subsidies and economic grievances, and the repression of civil society groups.

The Free Officers Revolution of July 1952 - the origin of modern authoritarianism in Egypt - involved the ousting of the constitutional monarchy of King Farouk by a military-led group known as The Free Officers. With an "imperfect but functioning parliament, and problematic but competitive elections,"1 Egypt prior to 1952 was one of the first "experiments" with democracy in the Arab world. ${ }^{2}$ Civil society organisations and multiparty politics emerged, however the king still held immense power, and the British maintained a noticeable presence. The Free Officers "condemned the corruption and inequalities of the old order." ${ }^{3}$ However, the successive regimes since the 1952 revolution have hardly stood out as bastions of democracy. Egypt's three authoritarian presidents

\footnotetext{
${ }^{1}$ Rex Brynen et al., Beyond the Arab Spring: Authoritarianism and Democratisation in the Arab World (Boulder, Colorado: Lynne Rienner Publishers, Inc., 2012). p 22.

2 Laurel E. Miller et al., Democratization in the Arab World: Prospects and Lessons from Around the Globe (Santa Monica, CA: RAND Corporation, 2012). p. 80.

${ }^{3}$ Brynen et al., Beyond the Arab Spring: p. 22.
} 
have all come from military backgrounds, and have exercised significant repression over any political opposition. In his history of Egypt, Tignor goes as far as to label them "Egypt's neo-Mamluks," ${ }^{4}$ after the powerful military caste of the eleventh century.

\section{Nasser's Era, 1952 - 1970}

Colonel Gamal Abdel Nasser was one of the leaders of The Free Officers, and assumed a number of deputy roles under the Egyptian Republic's first president, General Muhammad Naguib. Divisions between Naguib and other members of the Revolutionary Command Council (RCC), the postrevolution supervisory body, saw Nasser promoted to Chairman of the RCC. Following an assassination attempt against him in October 1954, Nasser gained immense support from the Egyptian population, and an overwhelming number of Egyptians approved his nomination for the presidency in a 1956 referendum. ${ }^{5}$

\section{The Economy and Political System}

Political life under Nasser was centred on the policy of "Nasserism," an ideological convergence of Arab Nationalism and Arab Socialism. Nasser positioned Egypt as the nation responsible for encouraging Arab Nationalism at a regional level, promoting the idea that a stronger Arab world would come as a result of political unification and distance from colonial influences. ${ }^{6}$ An attempt at closer regional ties was attempted in 1958, when Egypt and Syria took control over the Gaza Strip to form the United Arab Republic. Syria remained a part of this union until 1961, and Egypt was known as the United Arab Republic for a further ten years. Arab socialism comprised the economic arm of Nasser's ideology, with a focus on modernisation and state-led reform. In order to break Egypt's colonial economic pattern as an exporter of raw materials and importer of manufactured goods, and grow an independent Egyptian economy, Nasser initiated a programme of state-led economic development. He undertook a rigorous nationalisation of banks and European companies, and by the early 1960s, virtually every large-scale business was under state control. ${ }^{7}$ During this time, Nasser also maintained close ties with the Soviet Union, which influenced his pursuit of these socialist policies.

\footnotetext{
${ }^{4}$ Robert L. Tignor, Egypt: A Short History (Princeton, NJ: Princeton University Press, 2010). p. 2.

5 Ibid., p. 260.

${ }^{6}$ Scott Hibbard and Azza Salama Layton, "The origins and future of Egypt's revolt," Journal of Islamic Law and Culture 12, no. 3 (2010): p. 198.

7 Tignor, Egypt: A Short History: p. 271.
} 
Nasser also instigated important land reform policies, which transferred much of Egypt's arable land away from the hands of traditionally wealthy landowners, and into the hands of the Egyptian peasant classes. New laws limited any one individual's landholding to 200 acres, and a family's holding to 300 acres. $^{8}$ This was one of the key populist policies undertaken by Nasser, along with other social and welfare services that included subsidies for food, energy, housing, and transport, and free education and health care. ${ }^{9}$ Nasser's policies were held in high regard by the Egyptian population during the late 1950s and early 1960s. As Hibbard and Layton state, "through the redistribution of wealth and property, and the subsidies for education, food and rent, Nasser helped to create a modern middle class in what had previously been a highly inequitable socioeconomic order."10

Another significant economic spend was directed towards the military. The conflict with Israel and support for the Palestinian cause was one of Nasser's key policies, which he used to garner popular support within Egypt and throughout the wider region. The loss to Israel in the June 1967 War, therefore, had a significant impact on Nasser's popularity and his ideology of Arab Nationalism. Hibbard and Layton discuss this, stating that Nasser had done more than simply lose a war and a significant area of Egyptian territory; he had betrayed the "social contract" between the regime and the population. This informal contract involved "the population accepting constraints on its political freedom in exchange for the promise of higher living standards and a stronger nation." ${ }^{11}$ The loss to Israel drew attention to the concessions made by the population, and revealed how "the military had squandered its resources, failing to develop the country and proving themselves to be weak in precisely the area where they claimed to be strong." ${ }^{\prime 2}$

Nasser's political and economic policies did not quite have the intended impact. Many of the firms and assets which were nationalised were placed in the hands of managers selected from the military ranks, many of whom were inexperienced and, as Tignor states, "frankly incompetent."13 Additionally, Nasser promised public sector jobs to all graduates of Egyptian universities. The bloated civil sector took to producing commodities and offering services that were either too expensive for ordinary Egyptians or were sold far below cost price, with the government covering

\footnotetext{
8 Ibid., pp. 256-57.

${ }^{9}$ Dina Shehata, "The Fall of the Pharaoh," Foreign Affairs 90, no. 3 (2011): p. 27.

10 Hibbard and Layton, "The origins and future of Egypt's revolt," p. 199.

$11 \mathrm{lbid}$.

12 Ibid.

13 Tignor, Egypt: A Short History: p. 270.
} 
any losses. By the late 1960s, these factors were putting significant pressure on the Egyptian economy. ${ }^{14}$

\section{Civil Society}

Nasser's style of "personal authoritarianism" operated on the premise that the state would provide generous subsidies to the population in exchange for the population giving up their political freedom. ${ }^{15}$ Nasser established Law 32 in 1964, effectively banning all political and civic organisations. Groups had to register with the Ministry of Social Affairs and, in order to gain registration, had to adhere to the condition not to engage in any political activities. ${ }^{16}$ This effectively ruled out any chance an alternative group had to compete with the regime. As a result, many groups dissolved, found themselves rendered obsolete, ${ }^{17}$ or were consumed by the state, becoming "appendages of its bureaucracy." 18

Despite the repression of civil society organisations, both trade unions and professional syndicates managed to maintain a presence under Nasser. In order to garner support for the regime amongst workers, Nasser gave trade unions a relatively easy time. Trade unions were required only to register with the Ministry of Social Affairs, as opposed to request approval. ${ }^{19}$ This role was transferred to the newly created Ministry of Labour after 1962. Nasser's nationalisation programme made the state the biggest labour employer, and a number of laws were passed in the early 1960s to improve the lot of the labour force. This generosity gave the regime the power to "tailor the role of trade unions as it saw fit." ${ }^{20}$ However, the regime's control over the labour movement also prevented trade unions from becoming organisationally strong and a real threat to the regime. ${ }^{21} \mathrm{~A}$ similar level of control was exercised over professional syndicates, which Nasser viewed as an enemy of his new socialist order. ${ }^{22}$ As the state was such a major employer, Nasser was able to 'divide and conquer' many of the political syndicates through the enforcement of a number of restrictive laws, effectively neutralising them as a threat to the regime. ${ }^{23}$

\footnotetext{
14 Ibid., pp. 270-71.

${ }^{15}$ Hibbard and Layton, "The origins and future of Egypt's revolt," p. 199.

${ }^{16}$ Maye Kassem, Egyptian Politics: The Dynamics of Authoritarian Rule (Boulder, Colorado: Lynne Reinner Publishers, Inc., 2004). p. 88.

17 Ibid., p. 89

${ }^{18}$ Maha M. Abdelrahman, Civil Society Exposed: The Politics of NGOs in Egypt (Tauris Academic Studies: London, 2004). p. 128.

19 Kassem, Egyptian Politics: p. 91.

20 lbid., p. 93.

21 Ibid., p. 95.

22 Ibid., pp. 97-98.

23 Ibid., p. 99.
} 


\section{Sadat's Era, 1970 - 1981}

Nasser passed away from a heart attack in September 1970 and Anwar al-Sadat, who had held the post of vice president, inherited the presidency. Sadat's era as president was marked by a significant deviation from Nasser's political and economic direction. Following the 1973 Arab-Israeli War, Sadat intensified the peace process with Israel, signing the Camp David Accords in 1978, and eventually the Egyptian-Israeli Peace Treaty one year later. During this process, Sadat also developed much closer ties with the US. These policies were highly controversial amongst the Egyptian population, in particular the "abandonment of Nasser's anti-imperialism" ${ }^{24}$ for closer ties with the US. It was during this time that the US began to provide financial support to the Egyptian military, a policy that has persisted since. The US also became Egypt's largest trading partner and source of foreign investment. $^{25}$ As a result of developing relationships with Israel and the US, Egypt became increasingly distanced from other Arab countries. Nasser's vision of Egypt as the leader of Arab Nationalism in the region was well and truly abandoned.

\section{The Economy}

Sadat also abandoned Nasser's socialist policies in favour of infitah, or "open door" economic policies. Sadat's economic programme relaxed state control over the economy, and opened up Egypt to private investment, with an overall goal to "attract financial investment and technical expertise from abroad, and to integrate the country into the Western capitalist system." ${ }^{26}$ However, the expected outcomes of Sadat's new economic project were not realised. As Hibbard and Layton outline: "[f]oreign investment fell short of expectations, and gravitated toward sectors such as banking, tourism, and services. Very little investment went into manufacturing or agriculture, two sectors of the Egyptian economy that remain significantly under developed." 27 Also, the benefits of infitah only reached as far as the new commercial elite, many of whom had ties to the military, creating vast inequalities in wealth across society. ${ }^{28}$ Sadat also reversed Nasser's land reform policies, with his policy of de-sequestration returning vast tracts of land to the rural bourgeois, ${ }^{29}$ and began to dismantle the generous structure of state subsidies. This led to the outbreak of the Bread Riots in 1977, which Sadat ordered the military to contain. ${ }^{30}$ Sadat did however maintain Nasser's policy of providing employment in the public sector for university graduates. As the public-sector

24 Hibbard and Layton, "The origins and future of Egypt's revolt," p. 201.

${ }^{25}$ Karen Pfeifer, "Economic Reform and Privatisation in Egypt," in The Journey to Tahrir: Revolution, Protest, and Social Change in Egypt, ed. Jeannie Sowers and Chris Toensing (London: Verso, 2012), p. 205.

${ }^{26}$ Hibbard and Layton, "The origins and future of Egypt's revolt," p. 200.

27 lbid.

$28 \mathrm{lbid}$.

${ }^{29}$ Ninette S. Fahmy, The Politics of Egypt: State-Society Relationship (Oxford, UK: Routledge, 2002). p. 202.

${ }^{30}$ Hibbard and Layton, "The origins and future of Egypt's revolt," pp. 200-01. 
shrunk under his privatisation programme, the demand for employment increased, leading to "overstaffing, wasting time and resources." ${ }^{31}$ Under Sadat, the Egyptian economy became increasingly dependent on foreign income from sources such as oil, Suez Canal tolls, international tourism, remittances from the significant number of workers living abroad, and international aid and debt. $^{32}$

\section{The Political System}

Sadat's liberalisation of the economy extended into the political sphere to some extent. Sadat "dismantled the single-party system and permitted the re-establishment of political parties as an important feature of the new regime's image of both economic and political liberalisation." ${ }^{33}$ In early 1976, three 'platforms' emerged, which eventually developed into political parties. Notably, Sadat also permitted individuals to run as independent candidates. ${ }^{34} \mathrm{~A}$ number of explanations have been put forward as to why Sadat allowed for multipartyism to emerge. These include, first, that he wanted to gain support from domestic conservatives, who supported a more open political playing field, and move beyond the leftist support that Nasser had relied on. Second, in order to move away from Soviet allegiance and towards the sphere of the US, Sadat needed to at least appear as if he was embracing a more open political system. ${ }^{35}$ However, the National Democratic Party (NDP) remained the most influential political party, with new parties requiring government approval, and were constrained by a number of restrictions. ${ }^{36}$ The NDP also 'won' every election, with the process highly rigged in their favour. Electoral fraud under Sadat involved the harassment of opposition political parties, as well as a highly unequal distribution of resources, with the NDP receiving significant state sponsorship. ${ }^{37}$ This was the beginning of electoral authoritarianism in Egypt, used by both Sadat and his successor to cement their power. This phenomenon will be discussed in greater depth later in this chapter.

\section{Civil Society}

Under Sadat, civil society groups were given the space to exercise slightly more autonomy than they had under Nasser, however they too were bound by a condition not to challenge the regime's

\footnotetext{
31 Pfeifer, "Economic Reform and Privatisation in Egypt," p. 206.

32 Ibid., p. 205.

${ }^{33}$ Abdelrahman, Civil Society Exposed: p. 98.

${ }^{34}$ Lisa Blaydes, Elections and Distributive Politics in Mubarak's Egypt (New York: Cambridge University Press, 2011). p. 35.

35 Ibid., p. 36.

${ }^{36}$ Abdelrahman, Civil Society Exposed: p. 98.

37 Brynen et al., Beyond the Arab Spring: p. 22.
} 
authority. ${ }^{38}$ Sadat experienced significant protest from the labour sector during the 1970s. These protests were aimed at grievances stemming from the Nasser era, including economic underdevelopment and debt. ${ }^{39}$ Sadat's response was similar to that of Nasser's, involving a twopronged approach of "repression and concession." 40 For instance, following the strike of 10,000 workers at the Helwan Iron and Steel Company in August 1971, thousands were arrested and detained, following which Sadat tried to ease tensions by promising solutions. ${ }^{41} \mathrm{~A}$ resurgence of labour unrest occurred between 1975 and 1976 as workers became anxious at Sadat's infitah policies. International competition, the abandonment of Nasser's populist welfare policies, and increasing inflation exacerbated anxieties..$^{42}$ In March 1975, the military was deployed in response to a strike by textile workers in Mahalla al-Kubra, following which the situation turned violent. In order to control these protests, Sadat again pursued a policy of repression and concession.

The labour protests of the 1970s were largely organised on an informal basis, without the involvement of trade unions. However, the involvement of some unionists led to the government tightening their grip on the union movement. Law 35 of 1976 put in place a new electoral system for trade union officials, which "tightened governmental control over the selection of union activists on all levels, ${ }^{\prime 33}$ as well as heightened government involvement in the union electoral process. Despite keeping tight control over the union movement, Sadat kept up appearances with the workers themselves, offering various concessions including wage and pension increases. ${ }^{44}$ Professional syndicates experienced a change in fortune under Sadat. The number of syndicates increased during the 1970 s, along with total syndicate membership. ${ }^{45}$ Sadat's new economic approach incentivised professional syndicates to invest some of their earnings, subsequently shifting their traditional perceptions of the regime. ${ }^{46}$ However, the regime continued to exercise significant control over professional syndicates, preventing them from posing any real threat to Sadat's authority. As Kassem states, "Sadat demonstrated to the syndicates that the political and economic transformations that he pursued, and that they benefited from, should not be mistaken for genuine liberalisation and autonomy from state domination." ${ }^{47}$

\footnotetext{
${ }^{38}$ Abdelrahman, Civil Society Exposed: p. 98.

39 Kassem, Egyptian Politics: pp. 99-100.

40 Ibid., p. 100.

$41 \mathrm{lbid}$.

$42 \mathrm{lbid}$.

43 Ibid., p. 102.

$44 \mathrm{lbid}$.

45 Ibid., p. 103.

$46 \mathrm{lbid}$.

47 Ibid., p. 104.
} 
Sadat also built relationships with the Islamic community, namely the Muslim Brotherhood. Abdelrahman states that a key reason for this was to appease the Islamists, who disliked some of his new policies, particularly the peace arrangements with Israel, ${ }^{48}$ as well as garner grassroots support for his regime. ${ }^{49}$ Sadat also wanted to use the Islamists to counterbalance opposition from certain leftists groups, and factions remaining loyal to Nasser. ${ }^{50}$ Many Muslim Brotherhood members who had been arrested under Nasser were freed, and the proportion of Islamic NGOs registered with the government almost doubled. ${ }^{51}$ However, when Sadat realised the growing influence of the Muslim Brotherhood and other Islamist groups in the late 1970s, he again reverted to repression. ${ }^{52}$

It eventually became clear that Sadat's 'commitment' to political pluralism was merely a façade. His true authoritarian agenda shone through in a number of instances, including the introduction of emergency laws following the 1977 food riots, and "the law of aib (which literally means shame) that forbade any criticism of the regime as "unethical,"' as well as the widespread arrest of a number of his critics in the early $1980 \mathrm{~s} .{ }^{53}$ Sadat's delicate balancing act between opening up Egypt to the West and building closer ties with the US and Israel, as well promoting Islam as a counterweight to various ideologies from the Nasser era, eventually proved fatal. ${ }^{54}$ In October 1981 Sadat was assassinated by Islamist extremists at a military parade celebrating Egypt's victory in the 1973 war.

\section{Mubarak's Era, 1981 - 2011}

After Sadat's death, Hosni Mubarak moved into the role of president. Mubarak was the vicepresident under Sadat from 1975, and his policies were largely a continuation of those he inherited from his predecessor, particularly in the economic sphere. Mubarak's economic policies were based on neo-liberal concepts promoted by the International Monetary Fund (IMF) and the wider "Washington consensus." In Egypt this took the form of an intense process of liberalisation, privatisation, and deregulation, which was pursued during the course of the 1990s and into the 2000s. Other characteristics of Mubarak's era were the persistence of electoral authoritarianism and the state of emergency, as well as an expansion of civil society groups and subsequently the occurrence of protest.

\footnotetext{
${ }^{48}$ Abdelrahman, Civil Society Exposed: p. 98.

49 Hibbard and Layton, "The origins and future of Egypt's revolt," p. 201.

${ }^{50}$ Abdelrahman, Civil Society Exposed: p. 99.

$51 \mathrm{lbid}$.

52 Ibid., p. 138.

53 Ibid., p. 99.

${ }^{54}$ Hibbard and Layton, "The origins and future of Egypt's revolt," p. 201.
} 


\section{The Economy}

The first period of economic reform under Mubarak, beginning in 1991 and lasting through to 1998, began with the wiping of half of Egypt's foreign debt - largely accumulated during an intense infrastructure investment process during the $1980 \mathrm{~s}^{55}$ - following Mubarak's mobilisation of the Arab states to rally behind the US-led coalition against Sadam Hussein in Kuwait. ${ }^{56}$ This period was marked by an effort to stabilise Egypt's economy, with the government signing economic stabilisation programmes with both the IMF and World Bank in 1991. Other stabilisation policies were pursued, such as the liberalisation of interest rates, and the opening up of foreign currency to other sectors in addition to the commercial banking sector. ${ }^{57}$ Egypt joined the World Trade Organisation (WTO) in 1995, and signed the Greater Arab Free Trade Agreement in 1997, ${ }^{58}$ as well as a plethora of other free trade deals. ${ }^{59}$ In the second half of the 1990s, privatisation of state owned assets increased in Egypt, with 119 of 314 state owned enterprises either fully or partially sold. ${ }^{60}$

Economic reform in Egypt during the late 1990s and into the new millennium was marked by a focus on trade and the restoration of international confidence in the Egyptian economy. ${ }^{61}$ The global financial crisis of 1997 - 1999 put increasing strain on all economies competing in the international market. To add to this, trust in the Egyptian economy sunk following a terrorist attack at the popular Egyptian tourist destination of Luxor. ${ }^{62}$ During this period, Egypt signed further trade agreements; its involvement with the WTO pushing it to maintain international standards, particularly in the agricultural and industrial sectors. ${ }^{63}$ Ahmed Nazif, prime minister from $2004-2011$, is credited by foreign investors for pursuing a number of business-friendly reforms, including lowering taxation and inflation. ${ }^{64}$ Towards the mid-2000s, the privatisation process accelerated. Between 2004 and 2006, public sector companies and land underwent privatisation to the tune of 16 billion Egyptian pounds. ${ }^{65}$ Mubarak also took steps to improve Egypt's overall fiscal position, increasing the price of subsidised fuel and electricity. ${ }^{66}$

\footnotetext{
55 Hazem Fahmy, "An Initial Perspective on "The Winter of Discontent": The Root Causes of the Egyptian Revolution," Social Research 79, no. 2 (2012): p. 361.

56 Ibid., p. 362.

57 Sufyan Alissa, "The Political Economy of Reform in Egypt: Understanding the Role of Institutions," (Washington DC: The Carnegie Middle East Centre, 2007), p. 4.

58 Ibid., p. 5.

59 Fahmy, "An Initial Perspective on "The Winter of Discontent"," p. 362.

60 Pfeifer, "Economic Reform and Privatisation in Egypt," p. 208.

${ }^{61}$ Alissa, "The Political Economy of Reform in Egypt," p. 5.

62 lbid.

$63 \mathrm{lbid}$.

64 Pfeifer, "Economic Reform and Privatisation in Egypt," p. 216.

65 Alissa, "The Political Economy of Reform in Egypt," p. 6.

66 Ibid.
} 
Under Mubarak, the Egyptian economy did experience growth. Between 1996 and 2009, Egypt's annual real economic growth ranged between 2.8 and 6.4 percent. ${ }^{67}$ Egypt's economy proved more resilient than expected to the 2009 global financial crisis, with growth declining to only 4.7 percent in $2009 .{ }^{68}$ Gross Domestic Product (GDP) per capita also experienced growth from 5.3 percent in 2008, to 2.9 percent in 2009, and 3.3 percent in $2010 .{ }^{69}$ However, while this growth improved macroeconomic indicators, the microeconomic circumstances of ordinary Egyptians remained vulnerable. ${ }^{70} \mathrm{~A}$ number of reports indicate that poverty rose steadily under Mubarak, from 20 percent in 2000 to 25 percent in 2009, ${ }^{71}$ which Pioppi et al. label as a key indicator of Egypt's "increasing social deterioration."72 Egypt's wealth was heavily concentrated in the bank accounts of a few, with corruption reportedly common amongst top regime officials. Between 2000 and 2010, Egypt's 'crony capitalists,' among the wealthiest 10 percent of the population, captured on average over 25 percent of the nation's wealth. ${ }^{73}$ However, as I will discuss in later chapters, these inequalities are less severe than in many other countries, and have often been over-stated in the literature in an attempt to explain the Egyptian Revolution. Instead, perceptions of economic inequality have proved to be powerful motivators for mobilisation in Egypt, as opposed to actual material inequalities.

Other consequences of the economic direction under Mubarak included inflation and a rise in the price of food and other staples, as well as increasing unemployment. In 2008, a sharp increase in global food prices caused widespread angst and protest in Egypt, and elsewhere. The Food and Agriculture Organisation's (FAO) Global Food Price Index jumped to an average of 199.8 points in 2008, up from 158.7 in 2007. ${ }^{74}$ In Egypt, government subsidised bread supplies could not keep up with the pace of demand. People queued for hours to purchase what they could, with violent riots breaking out in May 2008. ${ }^{75}$ In January 2011, the FAO reported that the Food Price Index averaged

\footnotetext{
${ }^{67}$ Kinda Mohamadieh, "Egypt and the IMF: Conditions As Usual," Middle East Institute, 2013, Available Online at: http://www.mei.edu/content/egypt-imf-conditions-usual. (Accessed: 1 July 2013)

68 Pfeifer, "Economic Reform and Privatisation in Egypt," p. 220.

${ }^{69}$ Steve Hess, "From the Arab Spring to the Chinese Winter: The institutional sources of authoritarian vulnerability and resilience in Egypt, Tunisia, and China," International Political Science Review 34, no. 3 (2013): p. 256.

70 George Joffé, "The Arab Spring in North Africa: Origins and Prospects," The Journal of North African Studies 16, no. 4 (2011): p. 509.

71 Miller et al., Democratization in the Arab World: p. 86.

72 Daniela Pioppi et al., "Transition to What: Egypt's Uncertain Departure from Neo-Authoritarianism," in Mediterranean Paper Series 2011 (Washington DC: The German Marshall Fund of the United States, 2011), p. 11.

73 Miller et al., Democratization in the Arab World: p. 86.

${ }^{74}$ Food and Agriculture Organisation, "World Food Situation," Food and Agriculture Organisation, 2013, Available Online at: http://www.fao.org/worldfoodsituation/foodpricesindex/en/. (Accessed: 17 July 2013)

75 Chris McGreal, "Egypt: bread shortages, hunger and unrest," The Guardian, 2008, Available Online at: http://www.guardian.co.uk/environment/2008/may/27/food.egypt. (Accessed: 11 February 2013)
} 
231 points, a 3.4 percent increase from December $2010 .{ }^{76}$ As well as this, dramatic increases in energy costs in late 2010 and into 2011 can be observed. In December 2010, crude oil was priced at US\$91 per barrel, up from US\$75 in July, and jumped to US\$109 per barrel in March 2011. ${ }^{77}$ Alongside inflation and rising prices, the Mubarak regime also altered the social welfare system which had been in place since Nasser's time. Spending on education declined from 19.2 percent of total expenditure in 2002, to 11.5 percent in 2006. ${ }^{78}$ While spending on health increased from 2001 to 2008 , from 1.2 percent to 3.6 percent, this remained low when compared to other countries in similar economic positions. ${ }^{79}$ Again, the severity of these issues has been somewhat overstated by commentators attempting to untangle the complexities of the Egyptian Revolution, an argument I will return to later in this thesis.

Rising unemployment also proved a major issue under Mubarak, particularly among Egypt's university educated graduates. Unemployment reached 10 percent in 2009, up from 7.3 percent in 2000.80 This issue was particularly visible amongst the youth demographic. High fertility rates produced a significant 'youth bulge,' with 25 percent of the Egyptian population aged between 18 and $30 .^{81}$ In 2010, it was estimated that 90 percent of Egypt's unemployed were under the age of 30.82 Privatisation policies reduced the number of public sector positions, while employment opportunities in the private sector remained limited. ${ }^{83}$

\section{The Political System}

The liberalisation of the economy did not extend into the political sphere. Political competition was severely curtailed under Mubarak, despite the fact that shortly after coming to power, he released many of Sadat's political prisoners, and announced that he only intended to remain president for one term. ${ }^{84}$ However, Mubarak remained in power for five terms; a total of 30 years. Despite the fact that elections were held on a regular basis, the ruling NDP came out on top every time. This was due to the skewed political playing field that discriminated against other political parties, with an obvious imbalance in resources, media access, rampant intimidation of the opposition, and in many

\footnotetext{
${ }^{76}$ Food and Agriculture Organisation, "World food prices reach new historic peak," Food and Agriculture Organisation, 2011, Available Online at: http://www.fao.org/news/story/en/item/50519/icode/. (Accessed: 17 July 2013)

77 Joffé, "The Arab Spring in North Africa," p. 509.

78 Pioppi et al., "Transition to What," p. 17.

$79 \mathrm{lbid}$.

80 Miller et al., Democratization in the Arab World: p. 86.

81 United Nations Development Programme and the Institute of National Planning Egypt, "Egypt Human Development Report 2010," (United Nations Development Programme, 2010), p. 35.

82 Ibid., p. 6.

83 Pioppi et al., "Transition to What," p. 16.

${ }^{84}$ Fahmy, "An Initial Perspective on "The Winter of Discontent"," p. 368.
} 
instances, blatant vote rigging. Egypt provides, as Ottaway discusses, a "perfect model of semiauthoritarianism," where formal democratic institutions exist alongside opposition political parties, an active press, and civil society organisations. ${ }^{85}$ However, under Mubarak, Egypt's political system also "protects the government from real competition, limits the freedom of all organisations sufficiently to make them harmless to the incumbent leaders, makes it impossible to transfer power through elections, and maintains stability. ${ }^{186}$ For instance, under Mubarak opposition parties could publish material that criticised the government. However, the resources that these groups had access to was very limited when compared to the resources that flowed from the regime into statecontrolled newspapers, radio and television. As Tignor states, "[i]n any contest to reach the population with political and cultural messages, the government overwhelms the efforts of opposition groups." ${ }^{87}$ At election time a key opposition group, the Muslim Brotherhood, were not even permitted to register as a political party. They instead formed alliances with other opposition parties, or put forward independent candidates, in order to secure some degree of representation in government.

A classic hybrid regime, the Mubarak government used competitive elections to consolidate its power. Opposition parties largely had the opportunity to put forward candidates and run electoral campaigns, however they faced significant barriers, whereas the NDP were bestowed a number of advantages.$^{88}$ In fact, Blaydes argues that authoritarianism under Mubarak "endured not despite competitive elections, but, to some degree, because of these elections." ${ }^{\prime 9}$ Election served as an important tool for the Mubarak regime. First, they provided a means to ease the distributional conflict between elites over resources, as they provided both a public and credible forum for allocating resources. ${ }^{90}$ Second, they were also a means to provide the regime with information on the performance of NDP leaders and members. Third, they allowed Mubarak to "institutionalise [his] dominance through formal channels," ${ }^{91}$ largely to balance out the strength of the Egyptian military apparatus. ${ }^{92}$ Finally, they provided a guise for regime elites to hide corrupt activities, and added some degree of legitimacy to Mubarak's international reputation, ${ }^{93}$ particularly with the US. ${ }^{94}$

\footnotetext{
85 Marina Ottaway, Democracy Challenged: The Rise of Semi-Authoritarianism (Washington DC: Carnegie Endowment for International Peace, 2003). p. 31.

$86 \mathrm{lbid}$.

87 Tignor, Egypt: A Short History: p. 290.

${ }^{88}$ Beatriz Magaloni, "Credible Power-Sharing and the Longevity of Authoritarian Rule," Comparative Political Studies 51, no. 4/5 (2008): p. 728.

89 Blaydes, Elections and Distributive Politics in Mubarak's Egypt: p. 1.

90 Ibid., p. 3.

91 Ibid., p. 2.

92 Ibid., pp. 18-19.

93 Ibid., p. 2.

94 Ibid., p. 20.
} 
Elections, despite being risky, are worth it for any incumbent regime, as they "help to solve intraregime conflicts" that may have a destabilising effect on the regime, such as a coup or insider attempt to seize power. ${ }^{95}$ Holding elections manages to achieve this by demonstrating that a regime at least has "popular acquiescence" 96 - even if this has been bought - and in a less costly manner than resorting to violence. ${ }^{97}$

Opposition groups boycotted the 1990 elections as a protest against the fraudulent activities of the regime, however this only strengthened the NDP's monopoly over the National Assembly. Nevertheless, the opposition did achieve some progress after lodging an appeal with the Supreme Constitutional Court following the 1995 elections, protesting the fraudulent behaviour that occurred. This resulted in the monitoring of polling stations during the 2000 elections in an attempt to ensure fairness. ${ }^{98}$ The 2005 elections were also supervised by the judiciary, however being such an immense task, it was decided that voting would occur in three phases. After the first phase, many of the Muslim Brotherhood-affiliated candidates had done well, resulting in Mubarak and the NDP rigging the second and third rounds by employing armed thugs to intimidate voters at polling stations..$^{99}$ Nevertheless, the Muslim Brotherhood still managed to win an unprecedented 88 seats out of a total of $454 .{ }^{100}$ The 2010 elections are considered the most highly fraudulent of Mubarak's era. ${ }^{101}$ This was mainly orchestrated by Mubarak's son Gamal, heightening rumours that he was being groomed to inherit the presidency from his father. ${ }^{102}$ The 2010 elections, the last of the Mubarak era, resulted in the NDP controlling some 90 percent of the parliamentary seats. ${ }^{103}$ No opposition party managed to gain five percent of the seats, which was the threshold required for nominating a candidate for the presidency, meaning that once again Mubarak was the only candidate. $^{104}$

A further political characteristic of Mubarak's regime was the persistence of the state of emergency, which was put in place following the assassination of Sadat, and never lifted. The emergency laws,

\footnotetext{
95 Barbara Geddes, "Why Parties and Elections in Authoritarian Regimes?," in Annual Meeting of the American Political Science Association (Washington DC2005), p. 3.

96 Ibid., p. 23.

97 Magaloni, "Credible Power-Sharing and the Longevity of Authoritarian Rule," p. 728.

98 Ottaway, Democracy Challenged: pp. 43-44.

99 Fahmy, "An Initial Perspective on "The Winter of Discontent"," p. 370.

100 Ibid., pp. 370-71.

101 Ibid., p. 371.

102 See, for example: Muhammad Abdul Aziz and Youssef Hussein, "The President, the Son, and the Military: The Question of Succession in Egypt," The Arab Studies Journal 9/10, no. 1/2 (2001/2002); Mohammed Zahid, "The Egyptian nexus: the rise of Gamal Mubarak, the politics of succession and the challenges of the Muslim Brotherhood," The Journal of North African Studies 15, no. 2 (2010).

103 Fahmy, "An Initial Perspective on "The Winter of Discontent"," p. 371.

${ }^{104}$ Ann M. Lesch, "Concentrated Power Breeds Corruption, Repression and Resistance," in The Arab Spring in Egypt: Revolution and Beyond, ed. Bahgat Korany and Rabab El-Mahdi (Cairo: The American University in Cairo Press, 2012).
} 
which were originally intended to come into force when a threat was posed to public security or order, suspended the constitution and effectively eliminated any constitutionally protected rights. The emergency laws also placed significant restrictions on the civil liberties of the Egyptian people, allowing detention without charge and rigorous press censorship. During his time as president, Mubarak used the emergency laws to consolidate his power and suppress any attempt at opposition, particularly through the use of the emergency courts. Mubarak was allocated significant power over the emergency State Security Court, with the ability to appoint military judges in the place of the ordinary judiciary, as well as dictate procedural rules, and ratify any verdicts. ${ }^{105}$ Mubarak had the same authority over the various military courts which sprang up over the course of his term in office. ${ }^{106}$ According to one report, over 1000 civilian defendants were tried before such military courts between 1992 and 2000, with 92 sentenced to death and 664 to time in prison. ${ }^{107}$

The emergency laws also allowed for the development of police power and that of the wider security apparatus. Under the emergency laws, the State Security Agency (SSA), the main body responsible for national political security within the police force, was granted significant power. As Fahmy states, "[t]he SSA interfered in almost every aspect of life in Egypt, including approving all major appointments for government and elected positions to tighten control over domestic politics."108 SSA clearance was required for a number of academic and governance positions, and the SSA vetted entrance exams to the military, police, and security forces. The SSA was particularly harsh on universities and academics, interfering in research and even the choice of student textbooks. ${ }^{109}$ They formed a network of surveillance, tapping phone lines and spying on individuals to identify regime opponents. ${ }^{110}$ The security forces also recruited thugs to undertake much of the violent police brutality. As Fahmy outlines, "gangsters and criminals were recruited to launch physical attacks against political opponents, harass opposition journalists, intimidate voters to influence election results, or create havoc that would justify the annulment of unfavourable election results." ${ }^{111}$

Mubarak's regime also continued the traditionally close relationship between the regime and the military, one which Harb states was based on reciprocity. ${ }^{112}$ The military used its power and position in society to lend support to the regime, while the regime allowed the military to participate

\footnotetext{
105 Sadiq Reza, "Endless Emergency: The Case of Egypt," New Criminal Law Review 10, no. 4 (2007): p. 539.

106 Ibid., pp. 540-41.

107 Kassem, Egyptian Politics: p. 40.

108 Fahmy, "An Initial Perspective on "The Winter of Discontent"," p. 359.

109 Lesch, "Concentrated Power Breeds Corruption, Repression and Resistance," p. 25.

110 Fahmy, "An Initial Perspective on "The Winter of Discontent"," p. 359.

111 Ibid., p. 360.

112 Imad Harb, "The Egyptian Military in Politics: Disengagement or Accommodation?," Middle East Journal 57, no. 2 (2003): p. 287.
} 
extensively in the economy. During the Mubarak era, the military became involved in a number of industries and businesses, ranging from electronics and other consumer products, to tourism. The size of the military's business empire was extensive. While we do not have exact details, estimates put it somewhere between 10 and 40 percent of GDP in $2011 .{ }^{113}$ The military was also largely financially and institutionally independent, collecting all the revenue from its economic activities and allocating spending from a budget separate from that of the government. ${ }^{114}$ Despite their vital position, Frisch describes the military's status under Mubarak as "privileged yet subordinated."115 The military was economically strong, however the regime put in place a number of measures to prevent it from gaining too much power and influence, and therefore being in a position to directly challenge Mubarak. This included investing heavily in alternative security organisations, such as the police, at the expense of the military, and keeping members of the military out of positions of political power. ${ }^{116}$ This was despite the fact that the military continued to receive US\$1.3 billion from the US on an annual basis. ${ }^{117}$ The continuation of US military funding was a legacy of the Sadat era. On the foreign policy front, Mubarak remained close to the US, but also repaired Egypt's relationship with other Arab states, regaining membership in the Arab League in 1989.

\section{Civil Society}

Egyptian civil society under Mubarak experienced significant expansion. Despite the regime's blotted record of human rights violations and election manipulation, it can claim, somewhat ironically, to be Egypt's most 'democratic' regime since the 1952 revolution. ${ }^{118}$ During Mubarak's era, new civil society organisations sprung up where opposition political parties were silenced, particularly nongovernmental human rights organisations. The Arab Organisation of Human Rights, established in 1983, was the first human rights group in Egypt. ${ }^{119}$ One report estimates there were over 17,000 officially registered NGOs in Egypt by 2004, along with 23 trade unions, and 17 legal political parties ${ }^{120}$ In fact, Mubarak's regime almost "welcomed the involvement of NGOs in developmentrelated matters as they filled the gaps created after the state stepped back from this field."121 However, at the same time the regime did attempt to ensure that no civil society group ever gained

113 Derek Lutterbeck, "Arab Uprisings, Armed Forces, and Civil-Military Relations," Armed Forces \& Society 39, no. 28 (2012): p. 37.

114 Harb, "The Egyptian Military in Politics," pp. 285-86.

115 Hillel Frisch, "The Egyptian Army and Egypt's 'Spring'," Journal of Strategic Studies 36, no. 2 (2013): p. 182.

116 lbid., pp. 182-83.

117 Lutterbeck, "Arab Uprisings, Armed Forces, and Civil-Military Relations," p. 37.

${ }^{118}$ Abdelrahman, Civil Society Exposed: p. 108.

119 Vickie Langohr, "Too Much Civil Society, Too Little Politics: Egypt and Liberalizing Arab Regimes," Comparative Politics 36, no. 2 (2004): p. 187.

120 Kassem, Egyptian Politics: p. 104.

${ }^{121}$ Theodor Tudoroiu, "Assessing Middle Eastern trajectories: Egypt after Mubarak," Contemporary Politics 17, no. 4 (2011): p. 382. 
too much power, largely through tough electoral laws which prevented civil society groups from organising politically and posing a challenge to the presidency.

The expansion of civil society can be clearly seen through the groundswell of protest in Egypt, particularly over the last decade of Mubarak's rule. Protest against the regime involved three main 'spheres,' including the pro-democracy movement, the labour movement, and 'market-relationsbased' protestors. ${ }^{122}$ With the new millennium in Egypt came the beginning of a decade of visible protest. The outbreak of the second Palestinian intifada in 2000 brought Egyptians out onto the street to demonstrate on behalf of the Palestinians. Since this time, opposition politics in Egypt have been transformed, as discussed by Abdelrahman:

The intensification of protests and flourishing of activist groups mobilised large swathes of Egyptians across different socio-economic groups, crossing rural-urban divides, creating cross-ideological coalitions and using new forms of loose organisation structure outside decayed traditional political organisations. ${ }^{123}$

The pro-democracy movement largely comprised of human rights-based organisations, including the well-known Egyptian Movement for Change, who rallied under the slogan Kefaya ("Enough"), and the Popular Campaign for Change (Freedom Now). These groups, and a plethora of others, emerged prior to the 2005 elections, where they were strong advocates against Mubarak standing for another term, and for the potential for Gamal Mubarak to inherit the reigns of the presidency from his father. ${ }^{124}$ Other demands of Kefaya ranged from the lifting of the state of emergency, to complete regime change. ${ }^{125}$ Youth activists from Kefaya formed the April 6 Movement in 2008 as a show of solidarity with striking textile workers. ${ }^{126}$ This pro-democracy group played a key role in the 2011 revolution. The issues of police brutality were also taken up by pro-democracy groups and used as a point of protest against the regime. The group "We Are All Khaled Said" was launched online in 2010 to protest the death of a young man at the hands of the police, as well as the wider persistence of brutality amongst the Egyptian police and security forces. ${ }^{127}$

Labour protests under Mubarak largely took the same shape as they had under Sadat, characterised by spontaneity and unofficial organisation, largely due to the co-opted nature of wider trade union body: the Egyptian Trade Union Federation. However, protests were much more prolific, particularly in the last decade of Mubarak's rule. It is estimated that between 1998 and 2010, well over two

122 M. Abdelrahman, "A hierarchy of struggles? The 'economic' and the 'political' in Egypt's revolution," Review of African Political Economy 39, no. 134 (2012): p. 616.

123 Ibid., pp. 615-16.

${ }^{124}$ Rabab El-Mahdi, "Enough! Egypt's Quest for Democracy," Comparative Political Studies 42, no. 8 (2009): pp. 1012-13.

125 Abdelrahman, "A hierarchy of struggles?," p. 616.

${ }^{126}$ Shehata, "The Fall of the Pharaoh," p. 3.

${ }^{127}$ Abdelrahman, "A hierarchy of struggles?," p. 616. 
million Egyptians participated in over 3500 strikes and other collective actions. ${ }^{128}$ The most significant strikes of this decade occurred at Mahalla al-Kubra Spinning and Weaving Company in 2006. The impetus behind these strikes was the announcement of an annual bonus increase for public sector workers, as well as the nationwide trade union elections, which were considered to have been more fraudulent than usual. ${ }^{129}$ These strikes at Mahalla opened the floodgates of labour mobilisation in Egypt, with strikes in the following months by workers at the Helwan Cement Factory, and workers at the spinning and weaving companies in Shibin al-Kom and Kafr al-Dawwar. ${ }^{130}$ Egypt's labour movement began demanding better pay, job security, and working conditions, as well as tackling major policy issues, such as investigating corruption and challenging the IMF-led programme of privatisation. ${ }^{131}$

The third sphere of protest involved those who, as Abdelrahman frames it, "had lost any power to access or restructure market relations in their favour."132 These protestors came from all over Egyptian society, and included peasant farmers, who had lost their entitlement to their land following a 1997 legislation change, ${ }^{133}$ as well as street-stall vendors and small business owners. They voiced their frustration at the state's inability to provide them with basic services and infrastructure. ${ }^{134}$ These protestors were largely removed from the wider movement of political protest in Egypt, as they rarely called for the removal of the regime; more often than not simply calling for an improvement to their daily lives. ${ }^{135}$

A number of civil society groups in Egypt under Mubarak had roots in Islam. The Muslim Brotherhood, the most important Islamic group dating back to 1928, was barred from direct political involvement under Mubarak. In order to gain influence, the Muslim Brotherhood infiltrated many of Egypt's professional syndicates. ${ }^{136}$ This proved fruitful for the Brotherhood in the late 1980s and early 1990s, however legal obstacles put in place by the Mubarak regime made it increasingly difficult for the Muslim Brotherhood to maintain its foothold amongst the various professional syndicates. $^{137}$ The Brotherhood also attempted to gain political representation through covert

\footnotetext{
128 Joel Beinin, "Egyptian Workers and January 25th: A Social Movement in Historical Context," Social Research 79, no. 2 (2012): p. 326.

129 Ibid., pp. 328-29.

130 Abdelrahman, "A hierarchy of struggles?," p. 617.

131 Ibid.

132 Ibid.

133 Lesch, "Concentrated Power Breeds Corruption, Repression and Resistance," p. 27.

${ }^{134}$ Abdelrahman, "A hierarchy of struggles?," p. 617.

135 Ibid.

136 Kassem, Egyptian Politics: p. 112.

137 Ibid., pp. 112-16.
} 
coalition arrangements with opposition parties. ${ }^{138}$ However, the Muslim Brotherhood was not able to be constrained by the regime when it came to developing its influence through mosques, schools, and its vast network of charitable organisations. ${ }^{139}$ The Brotherhood was therefore able to build a sound base of support through these avenues, particularly amongst Egypt's dissatisfied poor. ${ }^{140}$

Other Islamist groups emerged under Mubarak, namely the Salafis; conservative Muslims who follow literal understandings of Islamic teachings. The political wing of Salafism in Egypt emerged out of the university network during the 1970 s. ${ }^{141}$ Despite traditionally adopting politically apathetic positions, the Salafis nevertheless experienced instances of repression under Mubarak. ${ }^{142}$ During the 1990s, political Salafism gained increasing momentum, due to the imprisonment of many Egyptian jihadists, and the continued repression of the Muslim Brotherhood. ${ }^{143}$ In the post-revolution space, the Salafis have emerged as a key political contender, despite traditionally shunning electoral politics. ${ }^{144}$

\section{The Media}

There was significant media repression in Egypt under Mubarak, particularly in the later years of his presidency. Prior to the 2010 elections, the government closed down 19 television channels, blocked numerous websites, and pressured privately-owned media outlets to stop using outspoken critics of the regime as guest writers or editors. ${ }^{145}$ Throughout the late 2000s, many journalists were beaten, fined, or imprisoned for investigations into issues such as police brutality or corruption, as well as for criticising Mubarak or his policies. Legislation passed in 2006 made it illegal for journalists to report 'fake' news stories that criticised the regime, punishable by up to five years in prison. ${ }^{146}$ These restrictions on press freedoms provided for a different media environment from the early 2000s, when a number of independent media outlets appeared, offering avenues for free expression. ${ }^{147}$

\footnotetext{
138 Laurence Caromba and Hussein Solomon, "Understanding Egypt's Muslim Brotherhood," African Security Review 17, no. 3 (2008): p. 119.

139 Ottaway, Democracy Challenged: p. 47.

140 Tudoroiu, "Assessing Middle Eastern trajectories," p. 384.

141 Khalil al-Anani and Maszlee Malik, "Pious Way to Politics: The Rise of Political Salafism in Post-Mubarak Egypt," Digest of Middle East Studies 22, no. 1 (2013): p. 59.

142 Ibid.

143 Ibid., p. 60.

144 Ibid., p. 62.

145 Lesch, "Concentrated Power Breeds Corruption, Repression and Resistance," p. 24.

146 Ibid., pp. 24-25.

147 Ibid., p. 24.
} 


\section{Conclusion}

Looking at the history of modern authoritarianism in Egypt is useful in assisting us to better understand the roots of the Egyptian Revolution. From a review of history we can see a number of common themes emerging across the three regimes. In the political sphere, the most obvious observation that can be made is the persistence of authoritarian rule that gripped Egypt from the 1952 revolution, and the continued influence of the military. All three presidents came from military backgrounds, and the military maintained a large and powerful presence under each successive president. A further political factor included the use of elections as a tool to consolidate the ruling NDP's hold on power. This occurred under both Sadat and Mubarak, where elections served to temper distributional conflict, offer vital intelligence for the regime, and provide a degree of institutionalisation and legitimisation to the regime. ${ }^{148}$ A variety of unfair measures were put in place to skew the political playing field, ensuring that no opposition party was able to gain a majority representation. On the economic front, the tradition of state subsidies for various goods and services remained largely uniform, and any changes to these policies was generally met with resistance. A number of economic issues persisted under each president, particularly those of unemployment and poverty. This was despite a number of changes in tack in the sphere of economic policy. The promotion of economic liberalisation under Sadat and Mubarak did not transfer into liberalisation in other domains of Egyptian society, with numerous restrictions on individual Egyptians' personal liberties and wider civil society movements. The Muslim Brotherhood in particular experienced significant repression since 1952. However, there has nonetheless remained a strong history of protest in Egypt, particularly amongst the labour sector.

Therefore, we can observe that Egypt experienced a long history of repression prior to the 2011 revolution. After considering the events of the revolution themselves in the next chapter, I will then turn to consider Egypt's authoritarian past alongside the theoretical frameworks discussed in Chapter One in an effort to determine whether or not the events that have transpired in Egypt support or challenge the existing literature.

\footnotetext{
148 Blaydes, Elections and Distributive Politics in Mubarak's Egypt.
} 


\section{Chapter Three The Egyptian Revolution: 2011 and Beyond}

\section{Introduction}

The 2010 self-immolation of Mohamed Bouazizi in the Tunisian town of Sidi Bouzid proved an historic turning point in global history, leading to widespread protests in Tunisia, Egypt, and across the Middle East, and the fall of a number of long-standing dictatorial regimes. This chapter provides an overview of the historic events that occurred in Egypt in 2011, and in the years since. In the intervening years since Mubarak's removal, Egypt has experienced continued demonstrations, widespread repression of opposition groups, and a second revolution with the military effectively removing democratically elected President Morsi in July 2013. The Egyptian 'transition' has not been a linear process in the direction of democracy, and in fact a reversion to authoritarianism has occurred.

\section{The Egyptian Revolution}

Protests in Egypt began on 25 January 2011, with demonstrators taking to the street for a 'day of rage' to protest against police brutality, on a day that was traditionally reserved for a celebration of Egypt's police forces. Protests in Egypt were centred in Cairo's Tahrir ('Liberation') Square, which became a globally-recognised symbol of the revolution. Other major protests occurred throughout Egypt, including in the cities of Suez, Alexandria and Asyut. Even nomadic Bedouin clashed with police in the Sinai Desert. ${ }^{1}$ Demonstrations were marked by the involvement of a spectrum of protestors from across Egyptian society. From the secular, leftist youth groups to the Muslim Brotherhood, and the women, working class citizens, and educated professionals in between, a vast array of people were drawn into the protest movement. ${ }^{2}$ Some of the key groups who played a part in the organisation of the initial demonstrations were the April 6 Movement, who emerged in 2008 in solidarity with the striking textile workers from Mahalla al-Kubra, and the Facebook group "We Are All Khaled Said," established in $\mathbf{2 0 1 0}$ following the death of Khaled Said at the hands of a group of police officers. These groups were joined by other organisations and political parties, including Kefaya and opposition figure Mohamed ElBaradei's National Association for Change. The demands

1 J. L. Gelvin, The Arab Uprisings: What Everyone Needs to Know (New York: Oxford University Press, 2012). p. 45.

2 Talal Asad, "Fear and the Ruptured State: Reflections on Egypt after Mubarak," Social Research 79, no. 2 (2012): p. 273;

Sherine F. Hamdy, "Strength and vulnerability after Egypt's Arab Spring uprisings," American Ethnologist 39, no. 1 (2012): p. 46; H. A. Hellyer, "The chance for change in the Arab world: Egypt's uprising," International Affairs 87, no. 6 (2011): p. 1316. 
made by the protestors were almost entirely secular, ${ }^{3}$ with a major focus on political freedom and respect for human dignity. Despite not being involved in the initial 'day of rage,' the Muslim Brotherhood did eventually join in with the demonstrations, and kept with the secular theme. In fact, during the protests in Tahrir Square, there were reports of the Muslim Brotherhood keeping watch while groups of Coptic Christians attended prayer, and vice versa. ${ }^{4}$ The main rallying call of the protestors, which echoed throughout Egypt and in the other centres of protest throughout the wider region, was ash-sha'b yurid isqaat al-nizaam; "the people want the downfall of the regime." ${ }^{5}$

Social media was a key organisational tool used by the demonstrators, as well as for generating and spreading outrage about the Mubarak regime, which had a powerful motivational impact. Social media technologies, such as Facebook, Twitter and YouTube, provided a forum for the expression of dissent that was exempt from traditional government controls, as it was largely anonymous and spontaneous. I will discuss the use of social media during the Egyptian Revolution in greater depth in the following chapter, alongside a discussion of democratic diffusion.

The Mubarak regime made a concerted effort to stop the protests. On 26 January, internet access was suspended to prevent demonstrations from being organised using social media platforms, causing a 90 percent drop in data traffic to and from Egypt. ${ }^{6}$ Mobile phone providers in Egypt were also ordered to suspend services. ${ }^{7}$ The regime ordered the police to crack down on protestors, with the 350,000 strong Central Security Forces attempting to control the crowds that had gathered across Egypt, and imposing a night time curfew, which many defied. ${ }^{8}$ However, the protests continued despite the best efforts of the regime to intimidate demonstrators into staying at home. The military played a pivotal role during the demonstrations. Despite being deployed in an attempt to enforce public order, ${ }^{9}$ the military was reluctant to damage its legitimacy and influence by directly firing on the protestors. Instead, it assumed the role of preventing clashes between the pro- and anti-Mubarak camps, as well as attempting to maintain a degree of order, but it did not directly

\footnotetext{
${ }^{3}$ Galal Amin, Egypt in the Era of Hosni Mubarak, 1981-2011 (Cairo: The American University in Cairo Press, 2011). p. 1. ${ }^{4}$ The Daily Mail, "Images of solidarity as Christians join hands to protect Muslims as they pray during Cairo protests," The Daily Mail, 2011, Available Online at: http://www.dailymail.co.uk/news/article-1353330/Egypt-protests-Christians-joinhands-protect-Muslims-pray-Cairo-protests.html. (Accessed: 16 August 2013)

${ }^{5}$ Andrea Teti and Gennaro Gervasio, "After Mubarak, Before Transition: The Challenges for Egypt's Democratic Opposition," Interface 4, no. 1 (2012): p. 103.

${ }^{6}$ Matt Richtel, "Egypt Cuts Off Most Internet and Cell Service," The New York Times, 2011, Available Online at: http://www.nytimes.com/2011/01/29/technology/internet/29cutoff.html. (Accessed: 18 September 2013)

${ }_{7}$ BBC, "Egypt severs internet connection amid growing unrest," BBC, 2011, Available Online at: http://www.bbc.co.uk/news/technology-12306041. (Accessed: 18 September 2013)

${ }^{8}$ Al Jazeera, "Protesters across Egypt defy curfew," Al Jazeera, 2011, Available Online at: http://www.aljazeera.com/news/middleeast/2011/01/201112816845606511.html. (Accessed: 23 January 2014)

${ }_{9}^{9}$ Rex Brynen et al., Beyond the Arab Spring: Authoritarianism and Democratisation in the Arab World (Boulder, Colorado: Lynne Rienner Publishers, Inc., 2012). p. 24.
} 
intervene to disrupt the demonstrations with force. ${ }^{10}$ The demonstrators viewed the military's position in a favourable light, and the chant "the army and the people are one"11 resounded throughout Egypt's centres of protest.

Signs that the Mubarak regime was weakening were clear from early February. In a speech to the nation delivered in Cairo on 1 February, Mubarak made a number of frantic promises in an attempt to appease the throngs of demonstrators. These included the appointment of Omar Suleiman as vice president, to "lead the improvements democratically and constitutionally" within the promised new government, as well as stating that he would not run in the next presidential elections, a decision which he apparently made "independent of the current events."12 On 5 February, a number of the NDP's senior leaders resigned, including Mubarak's son Gamal. Mubarak remained adamant that he would not step down, offering further concessions to the population, including the transfer of political authority to Suleiman. ${ }^{13}$ Mubarak made a second speech to the nation on 10 February, simply reaffirming that he would stay in power until September, when he would not contest the elections. He also promised national dialogue and the creation of a 'road map' to transition, and expressed sympathy with the demonstrators, stating: "I am very grateful and am so proud of you for being a symbolic generation that is calling for change to the better, that is dreaming for a better future, and is making the future."144 This only incensed the demonstrators, with crowds swelling the next day to march to the presidential palace to bring Mubarak down, forcefully if need be. ${ }^{15}$ This proved to be the final straw for the regime, with Mubarak resigning that evening, handing power to the Supreme Council of the Armed Forces (SCAF). Suleiman announced Mubarak's resignation in a brief statement, closing with the words "[m]ay God help everybody." ${ }^{16}$

\section{Post-Revolution Egypt}

Mubarak's resignation culminated 18 days of protest in Egypt. The protests were largely non-violent, however over 800 people were killed, and some 6000 injured. ${ }^{17}$ Following Mubarak's removal, protestors gathered once again in Tahrir Square, this time to clean up following the days of

\footnotetext{
${ }^{10}$ Tariq Ramadan, Islam and the Arab Awakening (New York: Oxford University Press, 2012). p. 28.

${ }^{11}$ Gelvin, The Arab Uprisings: p. 60.

12 Bahgat Korany and Rabab El-Mahdi, eds., The Arab Spring in Egypt: Revolution and Beyond (Cairo: The American University in Cairo Press, 2012), pp. 305-06.

${ }^{13}$ Ramadan, Islam and the Arab Awakening: pp. 28-29.

${ }^{14}$ Korany and El-Mahdi, The Arab Spring in Egypt, p. 307.

${ }^{15}$ Amin, Egypt in the Era of Hosni Mubarak: p. 2.

16 Korany and El-Mahdi, The Arab Spring in Egypt, p. 311.

${ }^{17}$ Ali Sarihan, "Is the Arab Spring in the Third Wave of Democratisation? The Case of Syria and Egypt," Turkish Journal of Politics 3, no. 1 (2012): p. 71.
} 
occupation; a symbolic display of new beginnings. ${ }^{18}$ A senior military commander, Field Marshal Mohamed Hussein Tantawi, was tasked with leading the SCAF, who would serve as a transitional government until elections could be held. Immediately following the revolution, the SCAF announced that the constitution would be suspended, parliament dissolved, and the military would rule for a period of six months, after which time elections would be held. ${ }^{19}$

The first round of voting since the ouster of Mubarak occurred on 19 March 2011, when Egyptians voted on the timeframe for transition, including the scheduling of the first parliamentary and presidential elections. However, under SCAF leadership Egypt seemed to take a backward step into its authoritarian past, with the persistence of the military justice system, restrictions on the media and civil society organisations, some mistreatment of women activists, and violence towards Christians, ${ }^{20}$ as well as continuing criticism that the military was attempting to hold onto power. It did not take long for Egyptians' attitudes towards the military to cool. On 1 April, protests to 'save the revolution' were staged throughout Egypt, with demonstrators demanding that the SCAF move faster to rid Egypt of elements of the former regime. ${ }^{21}$ In late May, the largest demonstrations since February occurred, with demands including that Mubarak be tried, elements of the old regime be removed from Cabinet, and the end to the emergency laws and the military court system. ${ }^{22}$ Throughout the rest of 2011, large scale demonstrations occurred on a regular basis, primarily orchestrated by the secular youth groups that had played such an integral part in the revolution. Despite the increasing incidence of violent demonstrations during these months, ${ }^{23}$ these groups did achieve some success. The elections planned for September were pushed back, and a Cabinet reshuffle resulted in the exit of many of the familiar faces from Mubarak's era. ${ }^{24}$ The most notable achievement was the beginning of Mubarak's trial in early August 2011. Facing charges of corruption and complicity in the killing of demonstrators, Mubarak was wheeled into a courtroom in a hospital bed. ${ }^{25}$ The trial was watched by millions across Egypt; the image of a meek Mubarak a powerful symbol of victory.

\footnotetext{
18 The Guardian, "Tahrir Square cleanup," The Guardian, 2011, Available Online at: http://www.theguardian.com/world/gallery/2011/feb/13/tahrir-square-cleanup-egyptpictures\#/?picture=371699176\&index=2. (Accessed: 11 August 2013)

${ }^{19}$ BBC, "Egyptian military dissolves parliament," BBC, 2011, Available Online at: http://www.bbc.co.uk/news/world-middleeast-12443678. (Accessed: 14 May 2013)

${ }^{20}$ Arch Puddington, "The Year of the Arab Uprisings," Journal of Democracy 23, no. 2 (2012): pp. 81-82.

${ }^{21}$ Neil McFarquhar, "Protesters Scold Egypt's Military Council," The New York Times, 2011, Available Online at: http://www.nytimes.com/2011/04/02/world/middleeast/02egypt.html? r=3\&. (Accessed: 14 May 2013)

22 Juan Cole, "Egypt's New Left versus the Military Junta," Social Research 79, no. 2 (2012): pp. 490-91.

23 Theodor Tudoroiu, "Assessing Middle Eastern trajectories: Egypt after Mubarak," Contemporary Politics 17, no. 4 (2011): p. 381.

${ }^{24}$ Cole, "Egypt's New Left versus the Military Junta," pp. 492-93.

25 Tudoroiu, "Assessing Middle Eastern trajectories," p. 381.
} 
However, these secular youth groups did not see all their demands realised, namely the postponing of elections until the constitution drafting process was complete. In November 2011, the first stage of the planned parliamentary elections took place, continuing through to completion in February 2012. The Islamists were the major victors once polls had closed, with the Muslim Brotherhood's Freedom and Justice Party dominating 47 percent of the seats in parliament, and the hardline Salafist Al-Nour party winning a further 29 percent. ${ }^{26}$ The Islamists had been the key supporters of early elections as they "calculated that their name recognition, resources and organisation would favour them over the secular and revolutionary parties." ${ }^{27}$ These latter groups, on the other hand, did not have the same historical depth or enough time to build the competitive party and campaign structures that would allow them to participate as equals. ${ }^{28}$ In addition, following the downfall of Mubarak, fissures began to appear amongst the revolutionary forces. The secular youth groups did not share a vision for the future, which further hindered them from mobilising into an organised political force. ${ }^{29}$ Despite a victory for the Muslim Brotherhood following this first round of parliamentary elections, constitutional restrictions allowing for the president to select the prime minister meant that power largely remained in the hands of the SCAF. ${ }^{30}$

The electoral process was not exempt from expressions of contention. In mid-December 2011, demonstrations were held in Tahrir Square. However, the protestors were met with a violent response from the police, who used tear gas and live bullets, killing ten and wounding hundreds. ${ }^{31}$ One poignant symbol of the brutality directed towards protestors that came from this round of demonstrations was that of the woman in the blue bra, who was viciously attacked, inciting comment from around the globe. ${ }^{32}$ Following this episode, the rights and honour of women became a central focus for the protestors. On 23 December, the April 6 Movement and Kefaya organised a demonstration to "regain the honour of women," following a lacklustre attempt from the SCAF to apologise for the recent surge in violence against women. ${ }^{33}$ By the first anniversary of the downfall of Mubarak, Egyptians' perception of the military and the SCAF had soured significantly. On 11 February 2012, 100,000 protestors gathered in Tahrir Square. Their rallying cry rang in stark contrast

\footnotetext{
${ }^{26}$ Teti and Gervasio, "After Mubarak, Before Transition," p. 103.

${ }^{27}$ Ewan Stein, "Revolution or Coup? Egypt's Fraught Transition," Survival 54, no. 4 (2012): p. 53.

28 Larry Diamond, "A Fourth Wave or False Start?," Foreign Affairs, 2011, Available Online at: http://www.foreignaffairs.com/print/67794. (Accessed: 13 June 2013)

${ }^{29}$ Hellyer, "The chance for change in the Arab world," p. 1316.

${ }^{30}$ Cole, "Egypt's New Left versus the Military Junta," p. 494.

31 Ibid., p. 495.

32 Ahdaf Soueif, "Image of unknown woman beaten by Egypt's military echoes around world," The Guardian, 2011, Available Online at: http://www.theguardian.com/commentisfree/2011/dec/18/egypt-military-beating-female-protestertahrir-square. (Accessed: 22 June 2013)

33 Cole, "Egypt's New Left versus the Military Junta," pp. 496-97.
} 
to the one they had chanted one year earlier - al chaab yourid isqat almuchir Tantawi ("the people want the overthrow of Marshall Tantawi"). ${ }^{34}$

In May 2012 the first round of voting for the presidential elections began, with a field of 13 candidates. Mohammed Morsi, the Muslim Brotherhood's presidential candidate, and Ahmed Shafiq, prime minister under Mubarak, were the winners of this round of voting, and challenged each other for the presidency the following month. Morsi emerged victorious by a small margin, winning 51.7 percent of the vote. During the final round of voting, the SCAF made moves to keep their hand on a degree of power before the new president was elected. They dissolved the Islamistdominated lower house of parliament, citing the law under which the elections were conducted was unconstitutional, and therefore illegal. They also issued a constitutional declaration on 17 June, which limited the power of the president, placing it back in their hands. ${ }^{36}$ This declaration limited much of the president's involvement in the military, and gave the SCAF significant influence over the drafting of the future constitution. ${ }^{37}$

Morsi undid much of the SCAF's attempt to hold onto power almost immediately after his official inauguration on 30 June, issuing his own constitutional declaration which annulled the SCAF's earlier one, ${ }^{38}$ as well as ordering the retirement of many military leaders who had served under Mubarak. In late November, Morsi issued further authority to himself, including granting his decisions immunity from judicial review, and preventing the dissolution of parliament. ${ }^{39}$ This led to large scale protests and clashes between supporters and opponents of Morsi, with some demanding that Morsi step down as president. This included influential opposition figure Mohamed ElBaradei, who Tweeted that Morsi had appointed himself "Egypt's new pharaoh." 40 Morsi quickly got to work on the constitution drafting process, and by the end of November a draft was completed. However, the process was entirely dominated by the Muslim Brotherhood and its allies, with secular groups largely boycotting the process. ${ }^{41}$ Morsi set the date for the referendum on the constitution for 15 December

\footnotetext{
34 Philippe Droz-Vincent, "Prospects for "Democratic Control of the Armed Forces"?: Comparative Insights and Lessons for the Arab World in Transition," Armed Forces \& Society 00, no. 0 (2013): p. 14.

35 The Carnegie Endowment for International Peace, "The Constitutional Declaration," The Carnegie Endowment for International Peace, 2012, Available Online at: http://egyptelections.carnegieendowment.org/2012/06/19/theconstitutional-declaration-with-june-17-2012-annex-added. (Accessed: 5 March 2013)

${ }^{36}$ Stein, "Revolution or Coup?," p. 53.

37 Droz-Vincent, "Prospects for "Democratic Control of the Armed Forces"?," pp. 16-17.

38 Ibid., p. 17.

39 BBC, "Egypt's President Mursi assumes sweeping powers," BBC, 2012, Available Online at: http://www.bbc.com/news/world-middle-east-20451208. (Accessed: 11 March 2013)

40 Mohamed ElBaradei, "Twitter Post," Twitter, 2012, Available Online at:

https://twitter.com/ElBaradei/status/271656968341581824. (Accessed: 17 March 2013)

${ }^{41}$ Al Jazeera, "Egypt's liberals stage walkout," Al Jazeera, 2012, Available Online at: http://www.aljazeera.com/news/middleeast/2012/06/201261214526684972.html. (Accessed: 3 April 2013)
} 
2012, which fuelled protests throughout early December. The referendum went ahead, with 63.8 percent voting in favour. However, voter turnout was very low, with only 32.9 percent of eligible voters participating. ${ }^{42}$ Following the referendum, opposition groups called for an investigation into allegations that the process had been a fraudulent one. ${ }^{43}$

On the two year anniversary of the revolution, thousands protested in Tahrir Square and throughout Egypt, demanding the removal of Morsi and the Islamist-dominated government. ${ }^{44}$ Demonstrations continued throughout March and April 2013, with massive protests outside the presidential palace on the one year anniversary of Morsi's election. A petition run by the opposition group Tamarod collected a reported 22 million signatures, demanding that Morsi stand down. ${ }^{45}$ On 3 July 2013, the military announced the end of Morsi's presidency, in a move that was labelled by many as a coup. ${ }^{46}$ This followed an ultimatum issued by the military 48 hours earlier: either Morsi meet the demands of the people, or it would step in to restore order ${ }^{47}$ Following this, Adly Mansour, the Chief Justice of the Constitutional Court, was appointed interim prime minister. These events prompted protests across Egypt from those who were supporters of Morsi, and violent clashes broke out between his supporters and opponents. ${ }^{48}$

\section{Conclusion}

Clashes between pro- and anti-Morsi camps, as well as protests against the military-installed regime, continued throughout 2013 and into 2014. Each anniversary of the 2011 ouster of Mubarak seems to dampen the euphoria and enthusiasm surrounding the original uprising a little more. ${ }^{49}$ The third anniversary of the Egyptian Revolution on 11 February 2014 was no exception, with protests held

\footnotetext{
42 BBC, "Egyptian voters back new constitution in referendum," $B B C, 2012$, Available Online at: http://www.bbc.com/news/world-middle-east-20842487. (Accessed: 24 March 2013)

${ }^{43}$ Abdel-Rahman Hussein, "Egypt referendum: opposition calls for fraud inquiry," The Guardian, 2012, Available Online at: http://www.theguardian.com/world/2012/dec/23/egypt-referendum-opposition-fraud-inquiry. (Accessed: 3 April 2013) ${ }^{44}$ Asmaa Waguih, "Egypt protesters, police clash on Mubarak anniversary," Reuters, 2013, Available Online at: http://www.reuters.com/article/2013/02/11/us-egypt-protests-idUSBRE91A0WQ20130211. (Accessed: 15 March 2013)

${ }^{45}$ Al Arabiya, "Anti-Mursi 'Rebel' campaign receives more than 22 million signatures," Al Arabiya, 2013, Available Online at: http://english.alarabiya.net/en/News/middle-east/2013/06/29/-Rebel-campaign-receives-more-than-22-millionsignatures-in-anti-Mursi-petition.html. (Accessed: 2 August 2013)

${ }^{46}$ Ben Wedeman, "Coup topples Egypt's Morsy; deposed president under 'house arrest'," CNN, 2013, Available Online at: http://edition.cnn.com/2013/07/03/world/meast/egypt-protests/index.html?hpt=hp t1. (Accessed: 2 August 2013)

${ }^{47}$ Salma Abdelaziz, "Egypt's military gives Morsy ultimatum," CNN, 2013, Available Online at: http://edition.cnn.com/2013/07/01/world/meast/egypt-protests/index.html?hpt=hp_t1. (Accessed: 23 September 2013)

${ }^{48} \mathrm{Al}$ Jazeera, "Scores killed in clashes at pro-Morsi rally," Al Jazeera, 2013, Available Online at: http://www.aljazeera.com/news/middleeast/2013/07/201372774215454742.html. (Accessed: 15 September 2013)

${ }^{49}$ Richard Youngs, "The Arab Spring Three Years On," The Carnegie Endowment for International Peace, 2014, Available Online at: http://carnegieeurope.eu/strategiceurope/?fa=54378. (Accessed: 11 February 2014)
} 
across Egypt, and a confirmed 49 deaths. ${ }^{50}$ In the intervening months, Egypt has been wracked with intense repression, directed in particular towards the Muslim Brotherhood. In March 2014, over 500 Muslim Brotherhood members were sentenced to death, reportedly over an incident that involved the death of a police officer. ${ }^{51}$ In April, at least a further 100 members were sentenced to jail time, charged with violence during protests in October 2013 demanding Morsi's reinstatement as president, ${ }^{52}$ and a number of Muslim Brothers were killed in on-going protests. ${ }^{53}$ The Muslim Brotherhood was also banned from putting forth any candidates in the upcoming presidential and parliamentary elections. ${ }^{54}$ This repression has led to increasing concern and condemnation from international governments and human rights groups directed towards Egypt's current military regime..$^{55}$

Egypt's 'transition' thus far has not moved in the direction of democracy. Instead, a reversion to authoritarianism has occurred, with commentators despondently announcing that Egypt is back at square one. ${ }^{56}$ We continue to hear reports of regime repression, namely towards the Muslim Brotherhood, and any democratic future for Egypt is looking increasingly bleak.

\footnotetext{
50 Patrick Kingsley, "Egypt: 49 people killed in protests on third anniversary of uprising," The Guardian, 2014, Available Online at: http://www.theguardian.com/world/2014/jan/26/egypt-49-killed-protests-third-anniversary-uprising. (Accessed: 11 March 2014)

51 Al Jazeera, "Muslim Brotherhood members sentenced to death," Al Jazeera, 2014, Available Online at: http://www.aljazeera.com/news/middleeast/2014/03/muslim-brotherhood-members-sentenced-death201432481112672803.html. (Accessed: 19 April 2014)

52 Deutsche Welle, "Egypt jails more than 100 Muslim Brotherhood supporters," Deutsche Welle, 2014, Available Online at: http://www.dw.de/egypt-jails-more-than-100-muslim-brotherhood-supporters/a-17573768. (Accessed: 19 April 2014)

53 Mohammed Tawfeed and Ralph Ellis, "2 Muslim Brotherhood members killed as unrest sweeps Egypt," CNN, 2014, Available Online at: http://edition.cnn.com/2014/04/11/world/africa/violence-in-egypt/. (Accessed: 19 April 2014)

54 J.C. Finley, "Egypt bans Muslim Brotherhood candidates from elections," United Press International, 2014, Available Online at: http://www.upi.com/Top_News/World-News/2014/04/16/Egypt-bans-Muslim-Brotherhood-candidates-fromelections/6061397657589/. (Accessed: 19 April 2014)

55 Deutsche Welle, "Egypt jails more than 100 Muslim Brotherhood supporters".

${ }^{56}$ Al-Sharif Nassef, "Revolution square one: Egypt three years on," Daily News Egypt, 2014, Available Online at: http://www.dailynewsegypt.com/2014/02/15/revolution-square-one-egypt-three-years/. (Accessed: 19 April 2014)
} 


\section{Chapter Four \\ 'Diffusion' and International Influences on the Egyptian Revolution}

\section{Introduction}

In Chapter One I discussed the various strands of theory that consider transitions away from authoritarianism and towards democracy. Despite a recent surge in academic interest surrounding these theories, much of it dates back a number of decades. This raises the question of whether or not events that have recently played out in Egypt challenge these theories, or if in fact they still provide useful explanations and assist in our understanding of transitions away from authoritarianism and the process of democratisation. The events that have transpired in Egypt support some strands of theory, and challenge others. Theories surrounding the diffusion of democracy and the impact of external actors, as well as ideas related to the influence of elites and civil society, are supported by the Egyptian case. Theories that emphasise economic factors garner less support from recent events in Egypt, as do arguments relating to religion and culture. The last three strands of theory will be discussed in later chapters. This chapter will consider the Egyptian case alongside theories of democratic diffusion and ideas related to the policies of external actors, including Levitsky and Way's discussion of Western linkage and leverage in hybrid regimes. It will argue that the Egyptian case provides support for ideas surrounding diffusion and international influence in terms of the upsurge of protest, but not democratisation.

\section{The Trigger of Tunisia}

Arguments surrounding the diffusion of democracy are popular amongst both the media and academic commentators who have documented the Egyptian Revolution, and the wider Arab Uprisings. As I discussed in Chapter One, the concept of democratic diffusion involves the conscious borrowing of "frames, strategies, repertoires, and even logos from previously successful efforts" and gaining "inspiration from the acts of others." ${ }^{1}$ In the case of the Egyptian Revolution, Tunisia has been popularised as the 'trigger' or 'spark' that instigated protests in Egypt, and elsewhere in the region. ${ }^{2}$ Protests in Tunisia, and the removal of longstanding autocrat Zine El Abidine Ben Ali, led the

\footnotetext{
1 Mark R. Beissinger, "Structure and Example in Modular Political Phenomena: The Diffusion of Bulldozer/Rose/Orange/Tulip Revolutions," Perspectives on Politics 5, no. 02 (2007): p. 263.

2 See for example: Rania Abouzeid, "Bouazizi: The Man Who Set Himself and Tunisia on Fire," Time Magazine, 2011, Available Online at: http://content.time.com/time/magazine/article/0,9171,2044723,00.html. (Accessed: 14 May 2013); Elizabeth Day, "The slap that sparked a revolution," The Guardian, 2011, Available Online at: http://www.theguardian.com/world/2011/may/15/arab-spring-tunisia-the-slap. (Accessed: 11 February 2013); The
} 
Egyptian revolutionaries to see parallels between their situation, and that of the situation in Tunisia. Aside from the fact that both Egypt and Tunisia had autocratic leaders, both countries experienced many of the same issues, such as high unemployment and entrenched corruption. ${ }^{3}$ As a result, the organisers of the demonstrations in Egypt consciously borrowed from the Tunisian case their methods of protest, as well as their demands and slogans. Even prior to the uprising beginning in earnest in Egypt, demonstrators held 'warm up' protests in solidarity with the Tunisians, where they waved Tunisian flags and chanted anti-Ben Ali chants. ${ }^{4}$ Following the symbolic self-immolation of Mohamed Bouazizi, several Egyptians emulated Bouazizi's act, ${ }^{5}$ as did others across the Middle East and even further afield. ${ }^{6}$ When the Egyptian demonstrations began, Tunisian revolutionaries shared tips with their Egyptian counterparts, with one activist posting on social media: "Advice to the youth of Egypt: Put vinegar or onion under your scarf for tear gas."

Bellin argues that while playing an important role in motivating protests in Tunisia and Egypt, the common economic and political grievances experienced by both Tunisians and Egyptians were not enough in isolation to incite such a surge in popular protest. She states:

Corruption, repression, and economic hardship had plagued both countries for decades, yet never before had they sparked popular protest in any sustained way. In addition, corruption, repression, and economic hardship had afflicted nearly every country in the region, sometimes to degrees that dwarfed the experience of Tunisia and Egypt. If depth of grievance were the sole factor determining the incidence of protest, Tunisia, certainly, would have been the least likely site for launching this sudden wave of mobilisation. ${ }^{8}$

Instead, Bellin argues that the trigger that motivated people to protest in Tunisia was outrage, which was sparked by two factors. The first was the self-immolation of Mohamed Bouazizi, and the second

Economist, "The scent of jasmine spreads," The Economist, 2011, Available Online at:

http://www.economist.com/node/18010573. (Accessed: 11 March 2013)

${ }^{3}$ Stephen M. Saideman, "When Conflict Spreads: Arab Spring and the Limits of Diffusion," International Interactions 38 , no. 5 (2012): p. 717.

${ }^{4}$ Daily News Egypt, "Egyptian activists call for protest in solidarity with Tunisians," Daily News Egypt, 2010, Available Online at: http://www.dailynewsegypt.com/2010/12/30/egyptian-activists-call-to-join-protests-over-tunisia-injustices/.

(Accessed: 17 June 2013) Jano Charbel, "Protest Stand in Solidarity with Tunisian Revolution", SHE212, 2011, Available Online at: https://www.blogger.com/profile/12892813403512393124. (Accessed: 17 June 2013)

${ }^{5}$ Saideman, "When Conflict Spreads," p. 718.

${ }^{6}$ Adam Lankford, "Suicide for a Cause: What's behind the Middle East's new trend of self-immolation?," Foregin Policy, 2011, Available Online at: http://www.foreignpolicy.com/articles/2011/01/19/suicide for a cause (Accessed: 17 March 2013); Sarah Kendzior, "The men who set themselves on fire," Al Jazeera America, 2013, Available Online at: http://www.aljazeera.com/indepth/opinion/2013/10/men-who-set-themselves-fire-20131075515834438.html. (Accessed: 3 November 2013)

7 Sahar Khamis and Katherine Vaughn, "Cyberactivism in the Egyptian Revolution: How Civic Engagement and Citizen Journalism Tilted the Balance," Arab Media and Society 13(2011): p. 11.

${ }^{8}$ Eva Bellin, "Reconsidering the Robustness of Authoritarianism in the Middle East: Lessons from the Arab Spring," Comparative Politics 44, no. 2 (2012): p. 136. 
was the Ben Ali regime's decision to respond to the initial demonstrations using force..$^{9}$ It was this outrage that "set alight the underlying tinder of long-term economic and political grievances." 10

Outrage was an emotion that brought people out onto the streets in Egypt as well. The brutal death of Khaled Said at the hands of police officers in 2010 served as the Egyptian equivalent to Tunisia's Bouazizi. However, an equally important trigger in the Egyptian case was euphoria. Ben Ali's rapid fall generated excitement and hope amongst Egyptians that they too could remove their longstanding autocratic leader. Bellin's analysis of outrage and euphoria in the Tunisian and Egyptian cases reveals the important role that emotions play in social mobilisation. ${ }^{11}$ Pearlman also discusses the role of emotion in the Arab Uprisings, arguing that different emotions promote different assessments of what the risks involved with a particular situation are. She states that "[e]motions of anger, joy, and pride increase risk assessment, prioritisation of dignity, and an optimistic readiness to engage in resistance."12 This is opposed to other emotions, such as fear and sadness, which encourage people to retreat and remain afraid. In the case of Egypt, emotions of excitement and hope were diffused following the removal of Ben Ali in Tunisia. This led to a shift in traditional perceptions of power relations in Egypt, ${ }^{13}$ and people overcame their longstanding fears of retribution and repression for standing up to the Mubarak regime. We can also observe instances where the diffusion of emotion did not result in people overcoming their fears. Pearlman cites the example of Algeria, which although exhibited a number of similarities with both Tunisia and Egypt, had an "emotional climate" which "increased aversion to risk, and hence a tendency towards resignation rather than resistance." ${ }^{14}$ This was due to its past experiences with democratisation, which resulted in a bloody civil war during the 1990s, and is still a recent memory for many Algerians. Therefore, in the Algerian case, fear acted as a barrier to mobilisation and rebellion. ${ }^{15}$

Events in Tunisia did act as proximate causes for the events that transpired in Egypt. There were certainly instances of intentional 'borrowing' from the Tunisian demonstrators, and the rapid downfall of Ben Ali did inspire activists in Egypt, and throughout the Middle East. Huntington discusses how democratisation has occurred in 'waves' throughout history; the first during the $19^{\text {th }}$ century in Western Europe and North America, the second following World War II in Southern

\footnotetext{
9 Ibid., pp. 136-37.

10 lbid., p. 136.

11 Ibid., p. 137.

12 Wendy Pearlman, "Emotions and the Microfoundations of the Arab Uprisings," Perspectives on Politics 11, no. 2 (2013):

p. 388.

13 Ibid., p. 399.

14 Ibid., p. 400.

15 Ibid.
} 
Europe, and the third from the mid-1970s in Central and South America, as well as Eastern Europe. ${ }^{16}$ A number of scholars have posed the question of whether the spread of demonstrations in the Middle East could be considered the 'fourth wave. ${ }^{17}$ There is no doubt that a 'wave' effect has occurred, however it seems that this 'wave' has been one more of demonstration than democracy. Democratic change has not yet materialised in Egypt. In fact, as I discussed in the previous chapter, a reversion to authoritarianism has occurred. Uninspiring results have been the hallmark of the socalled 'Arab Spring' in general, with a stalled transition in Libya, and violent civil war in Syria. Tunisia appears to be the only country that has made some progress towards democracy. This illustrates the classic example of demonstrators making 'cognitive shortcuts,' a phenomenon put forward by Weyland which I will discuss later in this chapter. ${ }^{18}$

\section{The Revolution Will Be Tweeted}

The diffusion of protest from Tunisia to Egypt was facilitated by the use of social media. Facebook, YouTube, and Twitter, as well as citizen journalism videos and blogs, allowed for information sharing to occur across borders almost instantaneously. Media reports and academic work outline the role that social media had in helping to organise demonstrations, and transmit messages and poignant images of revolution across the Middle East, and further afield. ${ }^{19}$ Social media proved an effective tool as it was cheap to operate and widely accessible. The "We Are All Khaled Said" Facebook page provided advice to demonstrators, such as "Egyptian flags only, no political emblems, no violence, don't disrupt traffic, bring plenty of water, don't bring your national I.D. card." ${ }^{20}$ However, as Hussein outlines, social media did more than simply change "the way political actors communicated - social movements and collective action networks shared strategies for direct political action, created regional and international news events that drew attention and sympathy from neighbouring countries, and inspired others to join and celebrate their causes." ${ }^{21}$ Social media also assisted in consolidating solidarity between demonstrators both within Egypt and across the Middle East, as it provided a means of sharing common experiences under authoritarianism, and common

\footnotetext{
${ }^{16}$ Samuel P. Huntington, The Third Wave: Democratization in the Late Twentieth Century, vol. 4 (Norman: University of Oklahoma Press, 1993).

17 Larry Diamond, "Democracy's Third Wave Today," Current History 110, no. 739 (2011); Larry Diamond, "A Fourth Wave or False Start?," Foreign Affairs, 2011, Available Online at: http://www.foreignaffairs.com/print/67794. (Accessed: 13 June 2013)

18 Kurt Weyland, "The Arab Spring: Why the Surprising Similarities with the Revolutionary Wave of 1848?," Perspectives on Politics 10, no. 04 (2012).

${ }^{19}$ Sam Gustin, "Social Media Sparked, Accelerated Egypt's Revolutionary Fire," Wired.com, 2011, Available Online at: http://www.wired.com/business/2011/02/egypts-revolutionary-fire/. (Accessed: 3 November 2013); Kellog Institute for International Studies, "The Tipping Point: Transitions to Democracy in Latin America and the Middle East," (Notre Dame, Indiana: University of Notre Dame, 2012).

20 Khamis and Vaughn, "Cyberactivism in the Egyptian Revolution," p. 11.

${ }^{21}$ Muzammil M. Hussain and Philip N. Howard, "Democracy's Fourth Wave? Information Technologies and the Fuzzy

Causes of the Arab Spring," in International Studies Association (San Diego 2012), p. 11.
} 
goals for life after authoritarianism ${ }^{22}$. Another important aspect was that social media, as well as satellite television, bypassed traditional authoritarian control and repression over anti-regime expression, such as the banning of public protests and censoring of speech and publications. As Bellin outlines, the largely anonymous and spontaneous nature of social media, as well as the foreign origins of satellite television, allowed for the dissemination of messages that the regime could not control through traditional means. ${ }^{23}$

A number of academics have argued that the role of social media was not as pivotal for explaining the spread of revolution as the previously mentioned accounts suggest. Weyland, for example, questions the link between social media and the diffusion of revolution, reminding us that the European revolutions of 1848 spread equally as fast as the protests in the Middle East, without the aid of Twitter, Facebook, and round the clock news channels. ${ }^{24}$ Lynch expresses doubts at the ability of social media to challenge authoritarian regimes by manoeuvring around their traditional controls, arguing that social media can instead be utilised by authoritarian states to crack down on opposition figures and organised demonstrations. Facebook was used as a surveillance tool by the Mubarak regime, allowing for the identification and punishment of regime opponents. ${ }^{25}$ Vodafone also worked closely with the regime, providing details on individual subscribers, and sending out proregime propaganda during the revolution. ${ }^{26}$ The regime also disabled internet connections and mobile phone networks across Egypt during the peak of the demonstrations. ${ }^{27}$ Others question the level of internet penetration in Egypt, arguing that social media cannot have played such a pivotal role in a country where only 25 to 30 percent of the population have access to the internet. ${ }^{28}$

Some accounts, particularly from the media at the height of the protests, seem to point to social media as a direct cause of the revolution. ${ }^{29}$ Statements such as these do appear to overstate the

\footnotetext{
22 Merlyna Lim, "Clicks, Cabs, and Coffee Houses: Social Media and Oppositional Movements in Egypt, 2004-2011," Journal of Communication 62(2012): p. 234.

${ }^{23}$ Bellin, "Reconsidering the Robustness of Authoritarianism in the Middle East," p. 138.

24 Weyland, "The Arab Spring," p. 919.

25 Marc Lynch, "After Egypt: The Limits and Promise of Online Challenges to the Authoritarian Arab State," Perspectives on Politics 9, no. 02 (2011): pp. 305-06.

${ }^{26}$ Ibid., p. 306.

27 Theunis Bates, "Protestors Left in the Dark as Egypt Blocks Internet," AolNews, 2011, Available Online at: http://www.aolnews.com/2011/01/28/protesters-left-in-the-dark-as-egypt-blocks-internet-cell-phone/. (Accessed: 11 June 2013); Andrew McLaughlin, "Egypt's big internet disconnect," The Guardian, 2011, Available Online at: http://www.theguardian.com/commentisfree/2011/jan/31/egypt-internet-uncensored-cutoff-disconnect. (Accessed: 14 July 2013)

${ }^{28}$ Rasha A. Abdulla, "The Revolution Will Be Tweeted: The Story of Digital Activism in Egypt," The Cairo Review of Global Affairs 3(2011): p. 41; Lim, "Clicks, Cabs, and Coffee Houses," p. 235.

${ }^{29}$ Roger Cohen, "Facebook and Arab Dignity," New York Times, 2011, Available Online at: http://www.nytimes.com/2011/01/25/opinion/25iht-edcohen25.html. (Accessed: 11 November 2013); Jose Antonio Vargas, "Spring Awakening: How an Egyptian Revolution Began on Facebook," New York Times, 2012, Available Online at:
} 
case. However, social media did provide an important platform for helping to build the momentum that was necessary for the spread of protest, as well as allowing for the dissemination of information and images to occur seamlessly across international boundaries. This is not to say that social media was the only method of spreading information during the demonstrations in Egypt. Traditional 'word of mouth' also played an important role. Lim in particular discusses the information sharing that went on in the "cabs and coffee houses" of Egypt. ${ }^{30}$ It was these traditional forms of communication that kept the demonstrations alive when the regime shut down modern communication channels, a tactic that did not have quite the effect the regime intended. As Lim points out, cutting off internet and telecommunications networks only fuelled the fire of protest, as opposed to extinguishing it. ${ }^{31}$ Also, many demonstrators had predicted that Mubarak would attempt to enforce an information blackout, organising satellite phones and dial-up connections to Israel and Europe. ${ }^{32}$ Google and Twitter also joined forces to offer the "Speak-2-Tweet" service, which allowed users to call an international telephone number to listen to and post Twitter messages, without an internet connection. ${ }^{33}$ 'Cyberskeptics' ${ }^{34}$ who cite a lack of widespread internet usage in Egypt often neglect to mention that the approximately 25 to 30 percent of Egyptians using the internet equates to over 20 million people. ${ }^{35}$ Egypt also has an impressive record of social media use in the Middle East, constituting over 20 percent of all Facebook users in the region, and nearly 80 percent of Facebook users aged 15 to $29 .{ }^{36}$

From an assessment of the events in Egypt, we can see that social media has proved more important than sceptics have claimed. Forums such as Facebook and Twitter were important tools for organising demonstrations, and sharing messages and images of revolution to motivate people to participate. However, it is important not to focus solely on new media in this process, as more traditional methods of communication played an important role. Also, despite being an effective tool in organising and mobilising dissent directed towards the regime, social media has not assisted in bringing about democratisation, a point that will be further elucidated in the following section.

http://www.nytimes.com/2012/02/19/books/review/how-an-egyptian-revolution-began-on-

facebook.html?pagewanted=all\& $r=0$. (Accessed: 11 November 2013)

30 Lim, "Clicks, Cabs, and Coffee Houses," p. 243.

31 Ibid., p. 244.

32 Hussain and Howard, "Democracy's Fourth Wave? Information Technologies and the Fuzzy Causes of the Arab Spring," p. 22.

33 Khamis and Vaughn, "Cyberactivism in the Egyptian Revolution," p. 15.

$34 \mathrm{~J}$. L. Gelvin, The Arab Uprisings: What Everyone Needs to Know (New York: Oxford University Press, 2012). p. 51.

35 Egypt's population is estimated at over 80 million. See: CIA, "The World Factbook: Egypt," CIA, 2014, Available Online at: https://www.cia.gov/library/publications/the-world-factbook/geos/eg.html. (Accessed: 15 March 2014)

${ }_{36}$ Lim, "Clicks, Cabs, and Coffee Houses," p. 235. 


\section{'Cognitive Shortcuts' in Egypt}

As discussed in Chapter One, a number of scholars have emphasised caution when it comes to following the prior example of others. Weyland compares the uninspiring results of the 1848 European Revolutions with the Arab Uprisings, arguing that in both cases, demonstrators made 'cognitive shortcuts' which resulted in disappointing outcomes. ${ }^{37}$ Demonstrators in Egypt, as well as other parts of the Middle East, "overrated the significance of the Tunisian success, overestimated the similarities with the political situation in their own country, and jumped to the conclusion that they could successfully challenge their own autocrats." ${ }^{138}$ Weyland infers that people got caught up in the 'here and now' and did not take into consideration a number of other factors, including the vast differences between Tunisia and Egypt in the nature of the state, role of the military, and the dynamics of the opposition movement. ${ }^{39}$ As a result, the situation that has transpired in Egypt has been somewhat disappointing, quashing the initial expectations and hopes of the demonstrators. ${ }^{40}$ Hale echoes this, arguing that the demonstration effect can result in the spread of protest, but that this will not necessarily result in regime change, and can in fact lead to further authoritarian repression. ${ }^{41}$ This is also emphasised by Bessinger, who focuses on the "unintended side effects of modular change." 42 He discusses how greater repression, violence and civil war can result when the structural conditions in one country are different to those in another. Syria's civil war provides a prime example of this, as does Egypt, where demonstrations and unrest have continued in the three years since the fall of Mubarak, as well as a coup which removed democratically elected President Morsi. The various Egyptian opposition groups have also faced challenges in the post-revolution space. As Lynch outlines, the majority of the opposition groups involved in the revolution were largely informal and leaderless organisations, which "do not necessarily translate into enduring movements or into robust political parties capable of mounting sustained challenge to entrenched regimes or to transforming themselves into governing parties." ${ }^{43}$

It is clear that the demonstration effect did play an important role in terms of the initial spread of protest from Tunisia to Egypt, and throughout the region. In Egypt, the spread of protest has not translated into the spread of democracy. There are a number of reasons for this, including the lack of translation of disparate opposition groups into a coordinated political force, and the actions of the

\footnotetext{
37 Weyland, "The Arab Spring," p. 917.

$38 \mathrm{lbid}$.

39 Ibid., p. 927.

40 Ibid., p. 928.

${ }^{41}$ Henry E. Hale, "Regime Change Cascades: What We Have Learned from the 1848 Revolutions to the 2011 Arab Uprisings," Annual Review of Political Science 16, no. 1 (2013): pp. 7-8.

42 Beissinger, "Structure and Example in Modular Political Phenomena," p. 273.

${ }^{43}$ Lynch, "After Egypt," p. 302.
} 
military in the post-regime environment. However, as Hale makes clear, we should not expect cascades of protest to turn into cascades of democracy, as this has not been the norm throughout history, where cascades towards hybrid regimes or autocracy have been common. ${ }^{44}$

\section{The Role of International Actors}

International academics and observers of the Middle East did not anticipate the Arab Uprisings. Despite their unexpected arrival, the Egyptian Revolution and the wider Arab Uprisings had deeper roots than simply a spark ignited in Tunisia. In Chapter One I covered Diamond's five models of diffusion, two of which I will focus on in this section which relate to the role of external actors. ${ }^{45} \mathrm{~A}$ number of external actors have played a role in democracy promotion in Egypt and the wider Middle East, particularly the US and the EU, as well as an array of NGOs. The Egyptian case lends support to the argument that democracy promotion efforts by international actors are important for transition movements. However, they were by no means the most important factor in Egypt and have not contributed to democratisation, namely because of the insufficient degree of Western linkage and leverage.

\section{The United States}

The promotion of democracy abroad has been a key tenet of US foreign policy since the early $20^{\text {th }}$ century, gaining momentum following the fall of the Soviet Union and communism in Eastern Europe. ${ }^{46}$ However, before the September 2001 terror attacks on the US, the Middle East was not explicitly included in this rhetoric, with the US more concerned with protecting its interests in the region. The US has maintained close ties with Egypt since the late 1970s. Democracy promotion during the 1990s was largely framed in economic terms, in order to avoid offending the regime and risking US interests in Egypt. ${ }^{47}$ Under President Clinton, the promotion of a strong civil society became an important aspect of US democracy promotion, based on the premise that free market reforms and the expansion of civil society would act as a precursor to democracy. ${ }^{48}$

\footnotetext{
${ }^{44}$ Hale, "Regime Change Cascades," p. 1.

45 Larry Diamond, Developing Democracy: Toward Consolidation (Baltimore, Maryland: The John Hopkins University Press, 1999). pp. 56-58.

${ }^{46}$ Erin A. Snider and David M. Faris, "The Arab Spring: US Democracy Promotion in Egypt," Middle East Policy 18, no. 3 (2011): p. 50.

47 Dionysius Markakis, "US Democracy Promotion in the Middle East: The Pursuit of Hegemony?" (The London School of Economics and Political Science, 2012), p. 118.

48 Ibid., p. 119.
} 
Following the September 2001 terror attacks, the US adopted a more aggressive foreign policy and democracy promotion approach, with the invasions of Afghanistan and Iraq. ${ }^{49}$ In his 2003 speech at the $20^{\text {th }}$ Anniversary of the National Endowment for Democracy, President George W. Bush made explicit reference to the need for Egypt to take a leadership role in progress towards democracy in the Middle East. ${ }^{50}$ Two years later, then Secretary of State Condoleezza Rice gave an address at the American University in Cairo, again explicitly calling for democratic reform of the Mubarak regime. She stated:

The Egyptian Government must fulfil the promise it has made to its people - and to the entire world - by giving its citizens the freedom to choose. Egypt's elections, including the Parliamentary elections, must meet objective standards that define every free election. Opposition groups must be free to assemble, and to participate, and to speak to the media. Voting should occur without violence or intimidation. And international election monitors and observers must have unrestricted access to do their jobs.

These bold statements reaffirmed the US commitment to democracy in Egypt, and the wider region. This commitment can be seen in the significant expansion of US funding for democracy promotion, from US\$500 million per annum in 2000 to over US\$2 billion per annum by $2005 .^{51}$ Democracy promotion in Egypt under President Bush had a continued focus on strengthening civil society, with the introduction of a number of new initiatives, such as the Middle East Partnership Initiative (MEPI), which provided support and training to civil society groups and individuals. ${ }^{52}$ However, the US's democracy promotion policies in Egypt were somewhat contradictory to their broader foreign policies in both Egypt and the wider region, which were largely concerned with security and counter terrorism. As Kitchen identifies, there were tensions between "long-term versus short term; hegemonic interest versus specific security priorities; stability versus reform." ${ }^{153}$

Under President Obama, democracy promotion efforts have become less aggressive, as Obama has attempted to distance himself from his predecessor's infamous 'freedom agenda. ${ }^{54}$ In his seminal speech at Cairo University in 2009, Obama showcased the new administration's gentler approach towards democracy promotion, making it clear that he did not want to get into another situation akin to Iraq. ${ }^{55}$ Obama has continued on with a number of democracy promotion initiatives

\footnotetext{
49 Ibid., p. 18.

50 National Endowment for Democracy, "Remarks by President George W. Bush at the 20th Anniversary of the National Endowment for Democracy," National Endowment for Democracy, 2003, Available Online at: http://www.ned.org/georgew-bush/remarks-by-president-george-w-bush-at-the-20th-anniversary. (Accessed: 23 September 2013)

51 Snider and Faris, "The Arab Spring," p. 52.

52 Markakis, "US Democracy Promotion in the Middle East: The Pursuit of Hegemony?," p. 125.

${ }^{53}$ Nicholas Kitchen, "After the Arab Spring: power shift in the Middle East?: the contradictions of hegemony: the United States and the Arab Spring," (London: London School of Economics and Political Science, 2012), p. 54.

54 Hussein Banai, "Democratic Solidarity: Rethinking democracy promotion in the New Middle East," Security Dialogue 55, no. 5-6 (2013): p. 422.

55 Ibid., p. 423.
} 
established under Bush, including the MEPI, increasing its budget to US\$65 million during his first year in office. ${ }^{56}$ During the Arab Uprising, the US played a mixed role, on the one hand joining with NATO to oust Gadaffi in Libya; and on the other remaining somewhat ambivalent towards its allies in Bahrain and Yemen. In Egypt, the US did not actively promote the spread of protest, instead appearing more concerned with its strategic interests, which were heavily tied to the Mubarak regime. ${ }^{57}$ However, one report does mention that the US utilised its leverage with the Egyptian military to ensure that the latter did not fire on protestors, in return supporting the military as the transitional authority. ${ }^{58}$ In a speech shortly following Mubarak's removal, President Obama announced his intention to support a transition to democracy in Egypt, promising US\$1 billion in debt relief and a further US\$1 billion to assist with job creation and rebuilding infrastructure. ${ }^{59}$

\section{The European Union}

The EU's involvement in democracy promotion in the Middle East began with the signing of the 1995 Euro-Mediterranean Partnership (EMP) in Barcelona. The primary focus of the EMP was economic reform and developing trade relationships, however the focus expanded to include such issues as migration, security, and counterterrorism. ${ }^{60}$ The EMP largely operated through a bilateral model, through Association Agreements between individual Middle Eastern countries and the EU, as opposed to widespread engagement with civil society. ${ }^{61}$ Egypt's Association Agreement was signed in 2001, and provided for EU democracy promotion through 'political dialogue.' However, it did not go any further than this in offering any tangible measures through which democracy was to be achieved.

Launched at the same time as the EMP was the Euro-Med initiative, which provided for an array of "security, economic, and social programs, including regular political conferences and democratisation programs as well as economic development loans." ${ }^{\prime 2}$ The EMP provided a formal channel to fund democracy assistance programmes in the Middle East. This occurred largely through the MEDA Democracy Programme, launched in 1996, which was the "EU's intended instrument for promoting the rule of law, human rights and democracy within the framework of the EMP."63

\footnotetext{
56 Snider and Faris, "The Arab Spring," p. 59.

57 Weyland, "The Arab Spring," p. 919.

58 Kellog Institute for International Studies, "The Tipping Point," p. 12.

59 Snider and Faris, "The Arab Spring," p. 59.

60 Jeffrey Kopstein, "The transatlantic divide over democracy promotion," The Washington Quarterly 29, no. 2 (2006): p. 92.

61 Ibid., p. 93.

62 Sheila Carapico, "Foreign Aid for Promoting Democracy in the Arab World," Middle East Journal 56, no. 3 (2002): p. 382.

63 Nesreen Khaled El Molla, "The EU's Role in Political Reform and Democracy Building in the Southern Mediterranean Region: An Egyptian Perspective," (Stockholm, Sweden: International Institute for Democracy and Electoral Assistance, 2009), p. 7.
} 
However, spending on democracy assistance was overshadowed by the funding for economic, trade and educational reform, ${ }^{64}$ with only 14 percent of the MEDA Democracy Programme budget going towards democracy promotion in the latter half of the 1990 s. ${ }^{65}$

The EU has traditionally viewed the Middle East through a security lens, with concerns surrounding Islamic fundamentalism and illegal migration. The aftermath of the 2001 terrorist attacks on the US saw a change in EU policy towards its neighbours to the south, with an increasing cross-over between security concerns and democracy agendas. ${ }^{66}$ In the post-2001 arena, the EU upgraded the EMP to the European Neighbourhood Policy (ENP), and introduced tailored Action Plans to prevent the new policy from reverting to 'one size fits all' model. ${ }^{67}$ The EU-Egypt Action Plan, signed in 2007, "defines the priority areas agreed by both parties to achieve a comprehensive set of reform measures in the political, economic and trade spheres," as well as timeframes for achieving various goals. ${ }^{68}$ The Action Plan went further than the Association Agreement, setting out provisions for political reform, as opposed to merely dialogue. ${ }^{69}$ However, the new agreement has come under criticism for excluding Egyptian civil society groups from the negotiation process, as well as merely being a token gesture in terms of the funding allocated for democracy promotion, which constitutes only seven percent of the total budget allocated for Egypt. ${ }^{70}$ During the 2011 demonstrations, the EU was slow to react and when it did, its position seemed hesitant. A joint statement issued by David Cameron, Angela Merkel, and Nicolas Sarkozy at the height of the protests only went as far as to inform Mubarak that he could not rely on European support to remain as president. ${ }^{71}$ This softer approach is typical of the EU's traditional democracy promotion rhetoric in Egypt.

\section{Transatlantic Democracy Promotion}

The US and EU have attempted to work together to promote democracy in the Middle East through a number of initiatives. In particular, The Broader Middle East and North Africa Initiative (BMENA), signed by the G8 in 2004, was a US-initiated forum for achieving cross-Atlantic cooperation in democracy promotion. However, at the time of its creation, the EU had a number of concerns with

\footnotetext{
${ }^{64}$ Ibid.

65 Richard Youngs, "The European Union and Democracy Promotion in the Mediterranean: A New or Disingenous Strategy?," Democratization 9, no. 1 (2002): p. 55.

${ }^{66} \mathrm{El}$ Molla, "The EU's Role in Political Reform and Democracy Building in the Southern Mediterranean Region: An Egyptian Perspective," p. 6.

67 Ibid., p. 8.

$68 \mathrm{lbid}$.

$69 \mathrm{lbid}$.

70 Ibid., p. 9.

${ }^{71}$ Anthony Dworkin, Daniel Korski, and Nic Whitney, "Egypt's Hybrid Revolution: A Bolder EU Approach," (London:

European Council on Foreign Relations, 2011), p. 1.
} 
the arrangement, including that the US was merely using the BMENA to leverage off its influence in the Middle East for its own gains, and also that the US's more aggressive policies would threaten the EU's softer stance. ${ }^{72}$ As a result, it did not take long for the BMENA to become a rather token forum, with little evidence of any tangible outputs, and lingering tensions between the EU and US over the direction of democracy promotion. ${ }^{73}$

Kopstein has argued that the US and EU's inability to work together in the name of democracy promotion stems from their differing interpretations of the Eastern European revolutions of 1989. The US viewed 1989 through a bottom-up lens, where civil society rose up to remove dictatorship and communism. The Europeans, on the other hand, viewed the Kremlin and Gorbachev's will to end the Cold War as the true origins of the 1989 revolutions. Civil society only became involved following this, with the job of creating democratic institutions and market economies. ${ }^{74}$ In the Middle East, US democracy promotion has relied on the 'stick doctrine,' with hard measures such as sanctions and funding cuts. On the other hand, the EU has followed the 'carrot doctrine,' with a focus on incentives and rewards. ${ }^{75}$ Kopstein goes on to argue that combining the US's focus on civil society, and the EU's focus on developing state capacity, could prove an effective model for transatlantic democracy promotion. ${ }^{76}$ However, this has not been the case in the past, as evidenced by the ineffective BMENA arrangement.

\section{Non-Governmental Organisations}

Non-governmental organisations have traditionally played an active role in the democracy promotion space around the world. US-based NGOs have complemented state democracy promotion efforts, with a major focus on the development of Egyptian civil society. The National Endowment for Democracy (NED) is one of the largest NGOs active in Egypt, and receives a considerable amount of funding through appropriations from the US government. ${ }^{77}$ Other NGOs, such as Freedom House, the National Democratic Institute, the Egyptian Democracy Institute, and the Egyptian Centre for Human Rights, are often contracted by NED to provide programmes and

\footnotetext{
72 Tamara Cofman Wittes and Richard Youngs, "Europe, the United States, and Middle Eastern Democracy: Repairing the Breach," (Washington DC: The Saban Centre for Middle East Policy, 2009), p. 3.

$73 \mathrm{lbid}$.

74 Kopstein, "The transatlantic divide over democracy promotion," pp. 86-87.

75 El Molla, "The EU's Role in Political Reform and Democracy Building in the Southern Mediterranean Region: An Egyptian Perspective," p. 6.

${ }^{76}$ Kopstein, "The transatlantic divide over democracy promotion," p. 97.

77 Markakis, "US Democracy Promotion in the Middle East: The Pursuit of Hegemony?," p. 65.
} 
initiatives, largely working with civil society groups and providing training, exchange programmes, and assistance. ${ }^{78}$

A significant network of NGOs based in Europe are also active throughout the Middle East, and Egypt in particular. The Westminster Foundation for Democracy, a body funded by the Foreign and Commonwealth Office, and the European Commission provide various groups with the funding to undertake democracy promotion work in the region. This includes such groups as the Austrian Study Centre for Peace, the Institut International des droits de l'homme, the International Institute for Democracy in Strasbourg, and the Dutch organisation NOVIB (the Nederlandse Organisatie voor Internationale Bijstand, now an Oxfam affiliate). ${ }^{79}$ European NGO involvement in Egypt has been at both the government and civil society levels. The Westminster Foundation, for instance, has been actively involved in a parliamentary strengthening programme since 2006. Their programmes have included training members of parliament, encouraging women into positions of leadership, and developing better policy making. ${ }^{80}$ Other NGOs, such as Oxfam NOVIB, have assumed a more grassroots approach, and have been active in the field of strengthening civil society and social and political participation in Egypt. ${ }^{81}$

\section{Were International Actors Important for the Egyptian Uprising?}

The evidence shows that there was a concerted effort by international actors to promote democracy in Egypt, most notably from the US and the EU. However, it is important not to see this as simply a one-way transaction. For instance, Egyptian activists sought their own learning and training from international sources. Rosenberg provides an account of how Mohamed Adel, an Egyptian activist and member of the April 6 Movement, travelled to Serbia to learn tactics of non-violent revolution at the Centre for Applied Non-Violent Actions and Strategies (CANVAS). ${ }^{82}$ CANVAS emerged out of the student group Otpor ('Resistance'), who were particularly active during the Bulldozer Revolution in Serbia in the late 1990s. Promoting strategies of non-violent protest and teaching people how to organise a mass movement, and then spread what they have learnt, CANVAS have influenced demonstrations and revolutions around the world - Zimbabwe, Iran, Myanmar, and Egypt; just to name a few. Egyptian civil society groups also possessed their own momentum; it was not simply

\footnotetext{
78 Ibid., p. 125.

79 Carapico, "Foreign Aid for Promoting Democracy in the Arab World," 383.

80 The Westminster Foundation for Democracy, "Annual Report and Accounts 2011/12," (London: The Westminster Foundation for Democracy, 2012), p. 7.

81 Oxfam International, "Egypt," Oxfam International, 2014, Available Online at: http://www.oxfam.org/en/egypt. (Accessed: 3 December 2013)

82 Tina Rosenberg, "Revolution U," Foreign Policy, 2011, Available Online at: http://www.foreignpolicy.com/articles/2011/02/16/revolution u?page=full. (Accessed: 14 November 2013)
} 
instilled on them by external actors. One key Egyptian opposition group - Kefaya - managed to become particularly influential without assistance from external actors. In fact, Kefaya refused to accept US democracy promotion assistance because it questioned its legitimacy, seeing it as an "extension of an imperial project associated with regime change in Iraq and doubted the US commitment, given its historical relationship with Egypt." 83

It is also difficult to directly tie international democracy promotion efforts to the events in Egypt. There is no denying the efforts of both US and EU actors to promote democratic ideals in Egypt, however it is difficult to measure the effect these have had, which suggests that they have been almost negligible. In fact, a study by the RAND Corporation suggests that democracy assistance to countries that are a US security priority, as indicated by their share of military aid, has been less effective. ${ }^{84}$ US policy towards Egypt included both democracy promotion and stability promotion. It appears that when stability promotion is identified as the priority, then democracy promotion is rendered irrelevant. US democracy assistance funding was dwarfed by its military aid budget. In the first five years after the September 11 attacks, US democracy assistance to the Middle East amounted to 80 cents per capita. This is significantly smaller than the US\$14.60 per capita spent in the former Soviet Union in the early 1990s..$^{85}$ The EU's outputs in Egypt are also difficult to measure, and its presence there has remained much less visible than that of the US. In fact, Hollis concludes that the EU's democracy assistance policies in Egypt did play a part in the uprising, however this was "by default rather than design." ${ }^{86}$ While it would be incorrect to say that international democracy promotion efforts had no impact in Egypt, there are questions surrounding its effectiveness, namely that it has been targeted towards elite advocates at the 'meso' level, as opposed to 'micro' level grassroots organisations, or even 'macro' level national reform efforts. ${ }^{87}$ In fact, Carapico goes as far as to state that international democracy promotion efforts in Egypt have proved largely irrelevant, and the "homegrown and organic" movement of 2011 was "a civic uprising of, by, and for Egyptians." 88

\footnotetext{
${ }^{83}$ Snider and Faris, "The Arab Spring," p. 54.

${ }^{84}$ Laurel E. Miller et al., Democratization in the Arab World: Prospects and Lessons from Around the Globe (Santa Monica, CA: RAND Corporation, 2012). p. 29.

85 Wittes and Youngs, "Europe, the United States, and Middle Eastern Democracy: Repairing the Breach," p. 11.

${ }^{86}$ Rosemary Hollis, "No friend of democratization: Europe's role in the genesis of the 'Arab Spring'," International Affairs 88, no. 1 (2012): p. 94.

87 Sheila Carapico, "Egypt's Civic Revolution Turns 'Democracy Promotion' on Its Head," in The Arab Spring in Egypt: Revolution and Beyond, ed. Bahgat Korany and Rabab El-Mahdi (Cairo: The American University in Cairo Press, 2012), p. 205.

88 Ibid., pp. 220-21.
} 
In their seminal work which I highlighted in the introduction of this thesis, Levitsky and Way label the degree of Western linkage and leverage as important factors for determining the trajectory of competitive authoritarian regimes ${ }^{89}$ The lack of democratisation in the Egyptian case can in part be explained by the lack of linkage and leverage. Egyptian economic, geopolitical and social linkage with the US and EU was not strong enough to have an impact on democratisation. The same can be said for Western leverage over the Mubarak regime. Egypt's position of geopolitical and strategic importance meant that security and stability were prioritised over pressure for democratisation. The Egyptian case therefore lends some weight to the argument that international actors have a role to play in the transition process. However, in this case international democracy promotion efforts have operated more as a minor influence of protest, as opposed to democratisation. This has been influenced by insufficient degrees of Western linkage, and minimal efforts at meaningful international leverage due to the prioritisation of security and stability over democracy.

\section{Conclusion}

The case of Egypt lends support to theories that focus on the diffusion of democracy and the role of international actors in encouraging protest, but not democratisation. We can clearly observe the demonstration effect at play, with the protests in Tunisia playing a key role in mobilising protests in Egypt, through both emotive and more technical channels. Diffusion via social media outlets was very important in the Egyptian case, both in terms of spreading information and facilitating ease of organisation, and allowing powerful messages and images to inspire others in disparate locations. However, it is important to stress that more traditional means of communication also played an important role in assisting in the organisation of demonstrations in Egypt. Diffusion through social media, as well as more traditional means, also failed to bring about democratisation, largely due to the overestimation of similarities between Egypt and Tunisia during the heat of revolution. International influences, namely from the US and EU, had a role to play, however these were by no means the most important factors that influenced the timing of Egypt's Revolution. It is crucial to be aware that democracy was not simply a foreign ideal bestowed upon Egyptians. Instead, Egyptian revolutionaries sought their own learning when it came to democracy. Also, it is important not to overstate the role of the US and EU, particularly when there are very few measurable outcomes that strongly link their activities with events in Egypt. In fact, it seems that the degree of Western linkage and leverage in the Egyptian case was very minimal largely due to the prioritisation of security and

\footnotetext{
${ }^{89}$ Steven Levitsky and Lucan A. Way, Competitive Authoritarianism: Hybrid Regimes After the Cold War (New York: Cambridge University Press, 2010). p. 23.
} 
stability concerns, which explains in part the absence of democratisation in the post-revolution space. 


\section{Chapter Five \\ Influences on the Egyptian Revolution: Elites and Civil Society}

\section{Introduction}

As I discussed in Chapter One, in the transitions literature there are two models which focus on the role of elites and civil society, as well as the interaction between the two, in an attempt to explain the movement away from authoritarianism and towards democracy. The first model takes a 'topdown' approach, looking at transitions as a controlled and negotiated process led by elites. The other looks at transitions from a 'bottom-up' perspective, focusing on the pivotal role of civil society and the wider public in general. Elite-led models do consider the role of civil society; however it is largely treated as an elite creation. This chapter will consider each model in the context of Egypt, as it is evident that the Egyptian Revolution was influenced by movements from both above and below. Elite influence in the Egyptian case can largely be attributed to the military, while influence from below has been widespread, stemming from the various movements that constitute Egypt's active civil society. The Egyptian case does not fit with O'Donnell and Schmitter's classic distinction between regime 'hardliners' and 'softliners,' ${ }^{1}$ as the division between the Mubarak regime and the military came about as a result of pressure from below, as opposed to any independent decision made by elites. This pressure from below contributed to the fall of Mubarak, but has not subsequently translated into a movement towards democracy. This can be attributed in part to civil society's lack of an elite ally, as the military's commitment to democracy has remained questionable, as well as the polarisation and lack of coherency between opposition civil society groups in the postrevolution space.

\section{The Egyptian Military}

The top-down model of transition pays particular attention to the role of elites in this process, focusing on transitions away from authoritarianism that are initiated or assisted by those in positions of power. In the Egyptian case, analysis of the role of the military fits with this model. As Barany makes clear, the military play a critical role during any revolutionary uprising. Military support for a revolutionary movement may not be sufficient for that movement's success, however it is a

\footnotetext{
${ }^{1}$ Guillermo O'Donnell and Philippe C. Schmitter, Transitions from Authoritarian Rule: Tentative Conclusions about Uncertain Democracies (Baltimore, Maryland: The John Hopkins University Press, 1986). p. 109.
} 
necessary feature. ${ }^{2}$ The military have traditionally been an important and influential body in Egypt, with a degree of political sway and a vast network of economic interests. Nasser, Sadat and Mubarak all had roots in the military, and their respective regimes relied on the military for support. As I discussed in Chapter Two, in the period immediately prior to the revolution, the military were perhaps not as politically powerful as they had been in the past. This was due to calculated actions by Mubarak, who had endeavoured to weaken the military in two ways, in order to prevent them posing a threat to his rule. First, he invested heavily in the police and other internal security organisations at the expense of the armed forces, elevating the police's power and influence in Egypt. $^{3}$ Second, Mubarak also ensured that no military officials were appointed to positions of political power. ${ }^{4}$ However, the military remained very economically strong, with a sizeable budget and discretionary spending, as well as generous tax breaks. Given the military's tradition of supporting the regime in return for the protection of its economic interests, ${ }^{5}$ observers and academics were less certain of how the military would respond to the demonstrations. ${ }^{6}$ At first appearing to support the regime, the military then resumed a somewhat neutral position between Mubarak and the demonstrators. It was not until the SCAF met without Mubarak on 10 February 2011, issuing their "Communiqué No. 1," that they explicitly vowed to "safeguard the people and protect their interests, security and safety," and approved the "legitimate demands of the people."7 This was an unprecedented move by the SCAF, who historically had only been convened on request by the chairman - the president - and did not make autonomous decisions. ${ }^{8}$

However, despite publicly positioning themselves on the side of the demonstrators and as supporters of the revolution's goals, a number of reports have cast doubt on the military's intentions, citing instances of heavy handedness towards protestors. Even though the military's actions were not on par with those of the police and other internal security forces, Lutterbeck claims that the military did mistreat some activists during the demonstrations, with a number of instances of arrest and torture. ${ }^{9}$ Holmes also tells of reports of violence towards demonstrators by the military. Even after promising solidarity with the protestors, the military reportedly failed to prevent

\footnotetext{
2 Zoltan Barany, "Comparing the Arab Revolts: The Role of the Military," Journal of Democracy 22, no. 4 (2011): p. 24.

${ }^{3}$ Hillel Frisch, "The Egyptian Army and Egypt's 'Spring'," Journal of Strategic Studies 36, no. 2 (2013): pp. 182 - 83.

${ }^{4}$ Ibid., p. 183.

${ }^{5}$ Imad Harb, "The Egyptian Military in Politics: Disengagement or Accommodation?," Middle East Journal 57, no. 2 (2003): p. 269.

${ }^{6}$ Barany, "Comparing the Arab Revolts," p. 28.

7 Tony Karon, "Mubarak Says He Is Handing Off Powers but Hanging On," Time Magazine, 2011, Available Online at: http://content.time.com/time/world/article/0,8599,2048250,00.html. (Accessed: 2 August 2013)

${ }^{8}$ The Carnegie Endowment for International Peace, "The SCAF: an Overview of its Actions," The Carnegie Endowment for International Peace, 2012, Available Online at: http://egyptelections.carnegieendowment.org/2012/01/05/the-scaf-anoverview-of-its-actions. (Accessed: 14 April 2013)

${ }_{9}^{9}$ Derek Lutterbeck, "Arab Uprisings, Armed Forces, and Civil-Military Relations," Armed Forces \& Society 39, no. 28 (2012): p. 38.
} 
violent attacks on peaceful demonstrators during the "Battle of the Camel" on 2 February 2011, where armed thugs on camel and horseback viciously attacked protestors camped out in Tahrir Square. ${ }^{10}$ In fact, Lutterbeck describes the military as somewhat reluctant supporters of the revolution, as they assumed a rather ambiguous position between the regime and the demonstrators, seeming unwilling to fully distance themselves from Mubarak. ${ }^{11}$ The ambiguity of their approach suggests that the military may have foreseen Mubarak's demise and were looking to safeguard their own interests, particularly their significant economic independence.

Nevertheless, a number of scholars have stressed that the stance taken by the military in 2011 was pivotal for Mubarak's downfall. Kandil, for example, states: "The military's abandonment of Hosni Mubarak's regime was essential for his downfall."12 Frisch echoes this, claiming that if the military had sided with the regime, the outcome could have been vastly different. ${ }^{13}$ Two key reasons have been articulated in the literature as to why the military took the stance they did in Egypt. First, the military were apprehensive about their prospects, particularly with regard to their economic interests, if Mubarak's son Gamal inherited the presidency from his father. ${ }^{14}$ Gamal Mubarak's support for privatisation policies was seen as a danger to the military's vast business empire. ${ }^{15}$ Another threat to the military's vast economic wealth was the position of the US. Despite initially supporting Mubarak, the Obama administration changed tack and increased pressure on Mubarak to step down. ${ }^{16}$ In siding with Mubarak, the military could have put at risk the US\$ 1.3 billion aid package it received from the US every year, as well as lucrative arms deals that meant the Egyptian military was among the most highly equipped in the Middle East. ${ }^{17}$

Second, the nature of the military itself had an impact on the position it assumed during the revolution. Egypt's significant number of conscript soldiers may have refused to shoot upon demonstrators, even if the top brass had ordered them to. ${ }^{18}$ Nepstad echoes this, also adding that the movement's largely nonviolent nature would have discouraged the military from responding

\footnotetext{
${ }^{10}$ Amy Austin Holmes, "There Are Weeks When Decades Happen: Structure and Strategy in the Egyptian Revolution," Mobilization 17, no. 4 (2012): p. 399.

${ }^{11}$ Lutterbeck, "Arab Uprisings, Armed Forces, and Civil-Military Relations," p. 39.

12 Hazem Kandil, "Back on Horse? The Military between Two Revolution," in The Arab Spring in Egypt: Revolution and Beyond, ed. Bahgat Korany and Rabab El-Mahdi (Cairo: The American University in Cairo Press, 2012), p. 175.

${ }^{13}$ Frisch, "The Egyptian Army and Egypt's 'Spring'," p. 188.

${ }^{14}$ Barany, "Comparing the Arab Revolts," p. 28.

${ }^{15}$ Sharon Erickson Nepstad, "Mutiny and nonviolence in the Arab Spring: Exploring military defections and loyalty in Egypt, Bahrain, and Syria," Journal of Peace Research 50, no. 4 (2013): p. 342.

16 Jeremy Bowen, "Egypt unrest: Obama increases pressure on Mubarak," BBC, 2011, Available Online at:

http://www.bbc.co.uk/news/world-us-canada-12371479. (Accessed: 8 August 2013)

${ }^{17}$ Nepstad, "Mutiny and nonviolence in the Arab Spring," p. 343.

18 Barany, "Comparing the Arab Revolts," pp. 28-29.
} 
with force ${ }^{19}$ This unwillingness to respond with violence would have been particularly strong amongst the 'rank and file' conscript soldiers, who would have perceived it as firing on their equals. ${ }^{20}$ At the same time, the Egyptian military was a highly professional force, which the literature argues is less likely to engage in indiscriminate repression. Lutterbeck discusses the degree to which military forces are institutionalised and the impact this has on whether a military will support a revolution or not. By institutionalised, Lutterbeck is referring to the degree to which the armed forces are "rule-bound and based on meritocratic principles.... Moreover, there is a clear separation between the private and public realms, so as to counteract corruption and security forces' predatory behaviour against society." ${ }^{21} \mathrm{~A}$ highly institutionalised military is more than likely committed to the country's wider national interest, as opposed to a particular individual or faction of society. ${ }^{22}$ Despite some reports of corruption in its upper echelons, the Egyptian military was regarded as a professional force with a true commitment to the Egyptian national interest and was one of the most highly respected institutions in the country. ${ }^{23}$

However, as Droz-Vincent notes, the degree of the military's professionalism and prestige does not necessarily illustrate a tendency towards democracy. Accepting that the military was viewed in a positive light by Egyptians in 2011, with some reports citing a popularity rating of 90 percent, ${ }^{24}$ he stresses that the military apparatus was a product of decades of authoritarian rule. He states: "authoritarianism has a propensity to produce (among the high officers' corps) its own creatures, characterised by a mix of unwavering loyalty, caution, and reluctance to change." ${ }^{25}$ This suggests doubts - which have since proved to be well founded - of the military's suitability to lead Egypt's transition.

The position that the military assumed during the 2011 demonstrations has directed Egypt's transition, and subsequent reversion to authoritarianism, over the last three years. At the time of Mubarak's removal, the military managed to position itself as the only political actor capable of beginning the task of transition. ${ }^{26}$ Despite initially declaring that it intended to take a step back from

\footnotetext{
${ }^{19}$ Nepstad, "Mutiny and nonviolence in the Arab Spring," p. 340.

20 Philippe Droz-Vincent, "Prospects for "Democratic Control of the Armed Forces"?: Comparative Insights and Lessons for the Arab World in Transition," Armed Forces \& Society 00, no. 0 (2013): p. 5.

${ }^{21}$ Lutterbeck, "Arab Uprisings, Armed Forces, and Civil-Military Relations," pp. 29-30.

22 Ibid., p. 30.

23 Ibid., p. 36.

${ }^{24}$ Laurel E. Miller et al., Democratization in the Arab World: Prospects and Lessons from Around the Globe (Santa Monica, CA: RAND Corporation, 2012). p. 84.

25 Droz-Vincent, "Prospects for "Democratic Control of the Armed Forces"?," p. 8.

${ }^{26} \mathrm{lbid}$.
} 
politics following a transition period of six months and 'return to the barracks, ${ }^{27}$ the military has continued to have an active involvement in Egyptian political life. ${ }^{28}$ As Droz-Vincent discusses, the military "showed discomfort with holding power for too long but at the same time left no room for civilian manoeuvrability. It sought to delegitimise opponents rather than negotiate with them." ${ }^{29}$ It did not take long for the SCAF's transitional regime to exhibit shades of Egypt's authoritarian past. In fact, soon after Mubarak's ouster, the military became increasingly repressive, violently removing demonstrators from Tahrir Square in April 2011, repressing bloggers, attacking Coptic demonstrators in what has become known as the October 9 Maspero massacre, and raiding the offices of a number of NGOs. ${ }^{30}$ Increasing levels of violence, as well as significant delays in responding to some of the key demands of the revolution, including the trial of Mubarak and an end to the state of emergency, ${ }^{31}$ and the prevention of two popular Islamist candidates from running in the 2011 presidential elections, ${ }^{32}$ hardly instilled hope that the military would support a smooth transition towards democracy. Protests in Tahrir Square demanded that the SCAF step down; a significant diversion from the adoring rhetoric directed towards the military in February 2011. When presidential elections resulted in the victory of Muslim Brotherhood candidate Mohamed Morsi, one of the first steps he took as Egypt's first democratically elected president was to remove the SCAF's power and influence. $^{33}$

For a few months, the military largely moved to the side of political life. However, they were only to re-emerge in mid-2013 to remove President Morsi in what many observers have labelled a coup, ${ }^{34}$ with General Abdul Fatah al-Sisi assuming the role of president. Since then, demonstrations and violent clashes have continued, largely between supporters of the Muslim Brotherhood and ousted President Morsi, and supporters of the military and al-Sisi. Despite many decrying the 2013 coup as an affront to democracy, the military once again appeared as the saviours of the people in many Egyptians' eyes. Al-Sisi has gained almost cult status amongst his supporters, with his image appearing on boxes of chocolates and even a sandwich being named in his honour. ${ }^{35}$ In March 2014,

\footnotetext{
27 The Carnegie Endowment for International Peace, "The SCAF: an Overview of its Actions".

${ }^{28}$ Kandil, "Back on Horse?," p. 193.

${ }^{29}$ Droz-Vincent, "Prospects for "Democratic Control of the Armed Forces"?," p. 11.

${ }^{30} \mathrm{Ibid}$.

31 J. L. Gelvin, The Arab Uprisings: What Everyone Needs to Know (New York: Oxford University Press, 2012). p. 64.

32 Frisch, "The Egyptian Army and Egypt's 'Spring'," p. 190.

33 Ibid., p. 195.

${ }^{34}$ Fawaz Gerges, "Egypt coup: the military has not just ousted Morsi. It has ousted democracy," The Guardian, 2013, Available Online at: http://www.theguardian.com/commentisfree/2013/jul/04/egypt-coup-military-morsi-democracy. (Accessed: 15 July 2013)

35 Ursula Lindsey, "The Cult of Sisi," The New York Times, 2013, Available Online at: http://latitude.blogs.nytimes.com/2013/09/12/the-cult-ofsisi/? php=true\& type=blogs\& $r=0$ \&version=meter+at+5\&region=FixedCenter\&pgtype=Blogs\&priority=true\&module=Reg iWall-Regi\&action=click. Accessed: 24 September 2013)
} 
al-Sisi gave an indication that he will run in the upcoming presidential elections, which he is widely expected to win. ${ }^{36}$ The events of the last year are concerning for the direction of Egypt's transition, and the prospect of democracy resulting from the country's turmoil is looking increasingly bleak. Despite originally pledging support for the revolution and the democratic demands of the people, the military has in fact assumed an increasingly authoritarian position, leading Droz-Vincent to conclude that "the military has remained a significant threat to democratisation and a source of uncertainty." ${ }^{37}$ This outcome is largely in line with what theorists have expected of the Egyptian military. ${ }^{38}$ Barany concludes that it is difficult to feel confident about the prospects of democracy in Egypt, given the military's tradition of political influence, as well as its vast economic interests. ${ }^{39}$ Kandil expresses a similar argument, drawing comparisons between the events of 1952 and 2011, and speculating that Egypt has simply returned to square one. ${ }^{40}$

\section{Conclusion on the Egyptian Military}

The elite-led model is supported to some extent by the Egyptian case, however it does not provide a sufficient explanation of events. While the role of the military elite was crucial in shaping events, other elites were not in such a strong position to determine the direction of the transition. This was largely because the Mubarak regime was completely devoid of legitimacy by the time of its downfall. The SCAF did not waste time in removing any traces of the Mubarak regime, immediately suspending the 1971 Constitution and dissolving both houses of parliament, as well as replacing many ministers who were "seen as tainted by their association with the prior regime." ${ }^{41}$ However, some elements of the old regime did remain involved, including the police and judiciary, both of which have maintained some degree of influence in the post-revolution space. ${ }^{42}$

A second conclusion we can draw from an analysis of the literature on elite-led transitions away from authoritarianism is that the process is portrayed in a somewhat controlled, negotiated and tidy manner, initiated and supported by elites. In practice, these theories often prove too

\footnotetext{
36 Patrick Kingsley, "Egypt army chief Abdel Fatah al-Sisi indicates he will run for presidency," The Guardian, 2014, Available Online at: http://www.theguardian.com/world/2014/mar/04/egypt-army-chief-abdel-fatah-al-sisi-indicates-runpresidency. (Accessed: 22 March 2014)

37 Droz-Vincent, "Prospects for "Democratic Control of the Armed Forces"?," p. 10.

38 Ellis Goldberg, "Mubarakism Without Mubarak: Why Egypt's Military Will Not Embrace Democracy," in The New Arab Revolt, ed. The Council on Foreign Relations (New York: The Council on Foreign Relations, 2011), p. 114.

39 Barany, "Comparing the Arab Revolts," p. 33.

40 Kandil, "Back on Horse?," p. 175.

${ }^{41}$ Miller et al., Democratization in the Arab World: pp. 97-98.

42 Nathan J. Brown and Michele Dunne, "Egypt's Judges Join In," Carnegie Endowment for International Peace, 2014, Available Online at: http://carnegieendowment.org/2014/04/02/egypt-s-judges-join-in/h6tf. (Accessed: 24 April 2014); Yezid Sayigh, "Reconstructing the Police State in Egypt," Carnegie Endowment for International Peace, 2013, Available Online at: http://carnegie-mec.org/2013/08/22/reconstructing-police-state-in-egypt/gjq6. (Accessed: 13 September 2013)
} 
straightforward. In Egypt, the continuing transition has proved far messier and complex than theorists of the elite-led model would have it. As the next section will discuss, Egypt's Revolution was largely influenced by momentum from below.

\section{Egyptian Civil Society}

As I discussed in Chapter One, an alternative model of transition focuses on the role of civil society movements and the wider public in influencing when and how a transition away from authoritarianism begins, as opposed to it being a process negotiated from above by those in positions of power. Such models also emphasise the vital role that civil society plays at all stages of transition - both away from authoritarianism and towards democracy, and beyond. This differs from elite-led theories, which although reserve a place for civil society, treat it as an elite creation and restrict it to the initial stages of transition away from authoritarianism, following which it is largely excluded.

The role of civil society proved crucial in the Egyptian case. There was a long history of active civil society movements in Egypt, dating back to the regimes of Nasser and Sadat. This was particularly true of groups originating from the labour sector and trade union movement. As I discussed in Chapter Two, both trade unions and professional syndicates maintained a presence under Nasser and Sadat. Labour movement protests were a hallmark of the 1970s in Egypt, and this continued on into Mubarak's era, with a spike in labour movement demonstrations in the years prior to the Egyptian Revolution. A significant pro-democracy movement also emerged under Mubarak, with groups such as Kefaya, the April 6 Movement, and "We Are All Khaled Said," among others, all with various origins. Kefaya emerged prior to the 2005 elections, largely to advocate against Mubarak standing for another term. The April 6 Movement emerged in a display of solidarity with striking textile workers in 2008, and "We Are All Khaled Said" was launched on Facebook in 2010 to highlight issues of police brutality. These groups all played a crucial role in the 2011 uprising in terms of mobilising demonstrators and spreading information, largely through social media channels. However, as I will discuss later, their role in the post-revolution space has not been as fruitful as hoped.

The Muslim Brotherhood is another civil society group who have been an important actor throughout Egyptian history, and played a pivotal role in the 2011 revolution. Following severe repression under Nasser, the Muslim Brotherhood was granted a degree of breathing space under

Sadat. As I discussed in Chapter Two, this position assumed by Sadat was for three key reasons: to 
appease the Islamists who disagreed with his policies (particularly peace with Israel), to leverage off the Brotherhood's widespread grassroots support, and to counter the influence of leftist groups. ${ }^{43}$ Under Mubarak, the Muslim Brotherhood was technically deemed illegal, however space was given to 'moderate' Brotherhood members. The Brotherhood built up their influence throughout Egypt in three main ways. First, through being elected as representatives through coalitions with opposition parties. Second, through increasing their control over professional syndicates and student unions. Finally, through filling the gap left by the state with their vast array of social service networks. ${ }^{44}$ Through these avenues, the Brotherhood developed a widespread base of support throughout society, largely originating from the mosques of Egypt. The Muslim Brotherhood used this to their advantage during the revolution, despite not initially joining in with the demonstrations. In the early days of transition, they emerged as the only real opposition party with a coherent organisational structure and power base to succeed in the post-revolution environment.

The emergence of these various civil society groups was significant for the Egyptian political space for a number of reasons. First, these groups were the first substantive opposition groups to emerge under Mubarak, as the opposition parties of the 1990s had only limited influence due to the restrictions placed upon them by the regime. Second, these civil society groups brought people together from across Egyptian society, with diverse political and religious orientations. Third, these groups also brought people together for the sole purpose of political liberalisation, as opposed to distinctive economic or regional concerns. ${ }^{45}$ This illustrated a significant diversion from the somewhat fractured nature of regime opposition in Egypt prior to the 2000s, which was largely covert and disguised as labour unrest, or expressions of solidarity with the Palestinian cause.

\section{The General Public}

Egypt's demonstrations also drew in members of the general public, a significant number of whom were not affiliated with any particular political or ideological grouping. These Egyptians were simply unsatisfied with their lot, and wanted to see a change in their daily situations; not necessarily a change in regime. Bayat distinguishes these protests from those of the Islamists, students and middle class professionals, arguing that a diverse group of people, namely the urban poor, women and youth, resorted to 'non-movements.' These 'non-movements' refer to "the non-deliberate and

\footnotetext{
${ }^{43}$ Maha M. Abdelrahman, Civil Society Exposed: The Politics of NGOs in Egypt (Tauris Academic Studies: London, 2004). pp. 98-99; Scott Hibbard and Azza Salama Layton, "The origins and future of Egypt's revolt," Journal of Islamic Law and Culture 12, no. 3 (2010): p. 201.

44 Laurence Caromba and Hussein Solomon, "Understanding Egypt's Muslim Brotherhood," African Security Review 17, no. 3 (2008): pp. 119-20.

${ }^{45}$ Rabab El-Mahdi, "Enough! Egypt's Quest for Democracy," Comparative Political Studies 42, no. 8 (2009): p. 1013.
} 
dispersed but contentious practices of individuals and families to enhance their life chances." ${ }^{16}$ This included simple acts such as securing shelter and earning a living, to persevering with education and, for women in particular, maintaining a presence in public. ${ }^{47}$ These non-movements generally avoided regime interference, so when instances of overt political protest began to increase in the 2000s, individuals who had been involved in non-movements began to take advantage of public opportunities to voice their discontent.

The general Egyptian public were not strangers to voicing their discontent. The Bread Riots, which broke out against austerity measures under Sadat's regime in 1977, are seen as the beginning of explicit public demonstration in Egypt. ${ }^{48}$ In the ten years prior to Mubarak's removal, instances of public protest intensified, and each protest helped to break down the 'wall of fear' that decades of living under authoritarian rule had instilled into the Egyptian people. ${ }^{49}$ In 2000 , widespread protests broke out in Egypt as a show of solidarity with the Palestinian intifada. ${ }^{50}$ Protests again erupted in 2003 following the US invasion of Iraq; the largest public demonstrations since the Bread Riots of 1977. ${ }^{51}$ In April 2008, two days of protest in Mahalla which began over the price of bread expanded into what has become known as the 'Mahalla intifada.'52 By 2011, the general Egyptian population had become a crucial part of the protest movement. As Bayat states, "[t]hese largely disparate voices and practices seemed to coalesce by the end of the 2000s to form the backbone of what came to be known as the Arab Spring." ${ }^{\prime 53}$

\section{Conclusion on Civil Society}

Considering Egypt's long history of demonstration, one could ask what it was about the protests of 2011 that managed to bring about such a significant sea change in Egypt. The answer is that protest in Egypt prior to 2011 was somewhat piecemeal. Never before had demonstrations drawn such large scale crowds from such a wide cross section of society. It was the factors discussed in the previous chapter - the emotional trigger of Tunisia, and the effective utilisation of social media platforms as both an organisational and motivational tool - that worked to mobilise civil society groups and the

\footnotetext{
${ }^{46}$ Asef Bayat, "The Arab Spring and its Surprises," Development and Change 44, no. 3 (2013): p. 588.

47 Ibid., p. 589.

48 Gelvin, The Arab Uprisings: p. 47.

49 Hossam el-Hamalawy, "Egypt's revolution has been 10 years in the making," The Guardian, 2011, Available Online at: http://www.theguardian.com/commentisfree/2011/mar/02/egypt-revolution-mubarak-wall-of-fear. (Accessed: 26 September 2013)

${ }^{50}$ Ann M. Lesch, "Concentrated Power Breeds Corruption, Repression and Resistance," in The Arab Spring in Egypt: Revolution and Beyond, ed. Bahgat Korany and Rabab El-Mahdi (Cairo: The American University in Cairo Press, 2012), p. 32. $51 \mathrm{lbid}$.

52 el-Hamalawy, "Egypt's revolution has been 10 years in the making".

53 Bayat, "The Arab Spring and its Surprises," p. 589.
} 
wider Egyptian public. This mobilisation was a process from below, which began amongst the people and worked its way upward to influence and destabilise elites.

Elite-led theories of transition do consider the role of civil society and movements originating from below. However, civil society is framed in the context of elites, with theorists arguing that divisions amongst the elites create the space for civil society groups to emerge. ${ }^{54}$ However, in the Egyptian case, civil society groups did not emerge as the result of elite initiation. Instead, as discussed previously in this section, there was a long history of active civil society in Egypt. Instead of emerging as a result of an elite-led transition away from authoritarianism, Egypt's transition began as a result of an active civil society movement. Elite-led theories also emphasise the role of civil society as being short lived. However, the role of civil society is instead continuous at all stages of transition both away from authoritarianism and towards democracy. In fact, in a more recent paper, Schmitter has admitted that since their initial work almost three decades ago, the role of civil society has proved more important than he and O'Donnell originally anticipated, particularly as a "force for transition." 55 This is illustrated by the Egyptian case, where civil society maintained a significant presence, particularly prior to and during the revolution.

Despite seemingly bringing about the downfall of Mubarak's regime with ease, the involvement of Egypt's lively civil society in the post-revolution space has been somewhat more difficult, and has not resulted in the emergence of democracy. Much of this can be attributed to the post-revolution stance of the military, who despite siding with the demonstrators during Mubarak's ouster, have since pursued an increasingly authoritarian agenda. Egyptian civil society has found itself in a difficult position without an elite ally to assist in a transition towards democracy. As well as this, many of Egypt's civil society groups who played such a pivotal role in the removal of Mubarak have lacked the capacity to turn their popular support into organised political support. In their discussion of hybrid regimes and the trajectories of transition, Levitsky and Way stress the importance of the strength and cohesion of opposition groups in determining outcomes. ${ }^{56}$ Where the organisational power of the opposition is low, transitions are often easy and spectacular. However, democratisation following what Levitsky and Way term "rotten door transitions" such as these proves much more difficult. ${ }^{57}$ This is for a number of reasons, including the weakened state structure and rule of law that follows such transitions, which hardly creates an environment conducive to

54 O'Donnell and Schmitter, Transitions from Authoritarian Rule: p. 26.

55 Philippe C. Schmitter, "Twenty-Five Years, Fifteen Findings," Journal of Democracy 21, no. 1 (2010): p. 24.

${ }^{56}$ Steven Levitsky and Lucan A. Way, Competitive Authoritarianism: Hybrid Regimes After the Cold War (New York: Cambridge University Press, 2010). p. 68.

57 Ibid., p. 354. 
democratisation. As well as this, rotten door transitions often fail to bring about institutional change, with the architecture of authoritarianism remaining firmly in place. ${ }^{58}$ Similarly, Collins discusses the concept of 'tipping point revolutions,' where a few days of intense protest often bring quick wins and emotionally satisfying outcomes. However, lasting change proves much more difficult without any deeper structural changes, and the results eventually prove disappointing. ${ }^{59}$ Complicating Egypt's rotten door transition has been the sharp polarisation of civil society into pro- and antiMuslim Brotherhood camps in the post-revolution space. Due to their long history and established networks throughout Egyptian society, the Muslim Brotherhood initially emerged as the only real candidate for assuming power. However, strong opposition to their presence in the post-revolution space was a factor that contributed to the military's removal of President Morsi in the 2013 coup, and the beginning of a reversion to military-led authoritarianism in Egypt.

\section{Influences from Above and Below}

As I discussed in Chapter One, a number of scholars argue that transitions away from authoritarianism and towards democracy can be influenced from both above and below. ${ }^{60}$ When looking at the Egyptian case, this pattern can be observed. From the top, influence stemmed from the position assumed by the military, whereas from the bottom, the role of civil society groups and the wider public shaped the nature and timing of transition. It is evident that in the Egyptian case, both models provide reinforcement for the other. The actions of the military provided the various civil society movements with the space to demonstrate, as it gave them confidence that they would receive military protection from the police and armed thugs employed by Mubarak. In return, the support of civil society bestowed upon the military the legitimacy to act as they did during the demonstrations, and in the post-revolution space. However, the primary influence for transition did come from below, as the demonstrations would not have begun, or garnered the momentum that they did, without a concerted effort by various civil society organisations determined to see Mubarak go.

\section{Conclusion}

We can observe that the Egyptian Revolution was influenced by the actions of both elites and civil society. The role of the Egyptian military was pivotal in that it allowed for the initial demonstrations

\footnotetext{
58 Ibid., p. 355.

59 Randall Collins, "Tipping Point Revolutions and State Breakdown Revolutions: Why Revolutions Succeed or Fail", The Sociological Eye, 2013, Available Online at: http://sociological-eye.blogspot.co.nz/2013/06/tipping-point-revolutions-andstate.html. (Accessed: 18 September 2013)

${ }^{60}$ Ruth Berins Collier, Paths Toward Democracy: The Working Class and Elites in Western Europe and South America (Cambridge: Cambridge University Press, 1999). p. 20.
} 
to occur. If the military had not taken the stance they did, and had instead sided with Mubarak and met the demonstrations with resistance, the outcome for Egypt would have been very different. However, the initial momentum for the demonstrations came from below; from civil society groups and the wider Egyptian public. As I discussed in Chapter Four, the inspiration of the Tunisians struck a chord with the Egyptian people, and the use of social media provided civil society groups and the general public with the platform to organise protests and share powerful images of revolution. Without this momentum from below, the protests would not have had the impact they did.

In the post-revolution space, the military has appeared to have a questionable commitment to a transition towards democracy, despite their initial support for the February 2011 demonstrators and their demands. In late April 2014, hundreds of Muslim Brotherhood members were sentenced to death, and the April 6 Movement - a pivotal group of the 2011 revolution - was banned. ${ }^{61}$ This has left Egyptian civil society groups without an elite ally to assist in the transition towards democracy. Also, the various civil society groups that proved so pivotal during the initial revolution have struggled to capitalise on their momentum, and translate it into an organised political framework, meaning they have so far largely been excluded from any official representation in post-revolution Egypt. These factors have meant that Egypt's transition has resulted not in a movement towards democracy, but instead a reversion to authoritarianism.

${ }^{61}$ BBC, "Egypt: Brotherhood's Badie among mass death sentences," BBC, 2014, Available Online at: http://www.bbc.com/news/world-middle-east- 


\section{Chapter Six Economic Factors and the Egyptian Revolution}

\section{Introduction}

Economic factors have been widely cited as one of the key 'causes' of the Egyptian Revolution, and the subsequent removal of Mubarak, by both academics and media commentators. However, as analysis in this chapter will reveal, economic arguments in fact garner less support from the Egyptian case than popular accounts suggest. In Chapter One, I discussed three theories relating to economics and transitions away from authoritarianism. First, this included a discussion of modernisation theory, a key theory debated by scholars of democratisation, which links improving levels of economic development to the emergence of democracy. ${ }^{1}$ Second, I discussed issues relating to economic inequality and democratisation. A number of scholars argue that highly unequal societies are unlikely to experience democratisation. This is because the ruling elites will choose to intensify repression to avoid democratisation and the subsequent redistribution of wealth and political power. ${ }^{2}$ However, others put forward the argument that highly equal societies are unlikely to experience democratisation either, as there is no real incentive to pursue regime change. ${ }^{3}$ Third, proponents of theories related to economic crisis argue that authoritarian regimes lack the legitimacy and effectiveness to deal with periods of economic crisis, and become unstable, thus paving the way for transitions to emerge. ${ }^{4}$ The following chapter will discuss modernisation theory, economic inequality and economic crisis in the context of the Egyptian Revolution, arguing that contrary to widespread belief, economic arguments are not strongly supported by the Egyptian case.

\section{Modernisation Theory}

There are two components to modernisation theory. First, modernisation theory provides an outline of a number of 'risk factors' that predispose a country to embark on a transition away from authoritarianism and towards democracy. These include increases in levels of industrialisation, urbanisation and education, among other factors. Second, modernisation theorists argue that transitions towards democracy which occur at higher levels of development will prove more

\footnotetext{
${ }^{1}$ See, for example: Ross E. Burkhart and Michael S. Lewis-Beck, "Comparative Democracy: The Economic Development Thesis," The American Political Science Review 88, no. 4 (1994): p. 903; David L. Epstein et al., "Democratic Transitions," American Journal of Political Science 50, no. 3 (2006): p. 552; Seymour Martin Lipset, "Some Social Requisites of Democracy: Economic Development and Political Legitimacy," The American Political Science Review 53, no. 1 (1959): p. 75. ${ }^{2}$ Carles Boix, Democracy and Redistribution (Cambridge: Cambridge University Press, 2003). p. 3.

${ }^{3}$ Daron Acemoglu and James A. Robinson, Economic Origins of Dictatorship and Democracy (Cambridge: Cambridge University Press, 2006). p. 38.

${ }^{4}$ Juan J. Linz and Alfred Stepan, Problems of Democratic Transition and Consolidation: Southern Europe, South America, and Post-Communist Europe (Baltimore, MA: The John Hopkins University Press, 1996). p. 79.
} 
enduring. In the Egyptian case, we can observe aspects of modernisation theory at play with increases in education levels, a growing middle class, increases in international trade, investment and tourism, as well as less tangible shifts in values and attitudes. These factors contributed to dissatisfaction amongst the middle class, and encouraged participation in protest, so we can see that some instability was predicted for Egypt. However, as well as being a theory of transition away from authoritarianism, modernisation is also a theory of transition towards democracy, which has not occurred in the case of Egypt. This illustrates a weakness of modernisation theory, in that it does not account for cases of regime breakdown, and the significant societal divisions and state weakness which follow such events.

\section{Education Levels}

Modernisation theorists associate increases in levels of education with the development of democratic aspirations, as well as the characteristics that complement democracy, including trust, satisfaction and competence. ${ }^{5}$ Education levels in Egypt experienced growth in the years leading up to the revolution. In 2011, secondary enrolments sat at 86 percent, above the regional average of 71 percent, and up from 74 percent in 1991. The same picture can also be seen at the tertiary level, with enrolments sitting at 29 percent in 2011, above the regional average of 23 percent, and up from 12 percent over the last two decades. Literacy rates in Egypt have also experienced an increase. Literacy rates amongst youths (ages 15-24) were 89.3 percent in 2012, up from 63.3 percent in 1986 and 84.9 percent in 2006. Literacy rates amongst adults have also improved, sitting at 73.9 percent in 2012, up from 44.4 percent in 1986 and 66.4 percent in $2006 .{ }^{6}$ In 2007, the Mubarak government began a complete overhaul of the Egyptian education system, with increases in teacher salaries, improvements in school facilities, and a redesigned curriculum. ${ }^{7}$ Research has shown that people with higher education levels assign greater importance to democracy and individual freedom, and are more likely to be aware and connected to the situations of people in similar positions as themselves across the world. ${ }^{8}$ However, improvements in Egypt's education rates were not exclusively the result of state-led efforts. In fact, in a 2011 survey only 18 percent of Egyptians expressed satisfaction with the education opportunities that had been provided by the

\footnotetext{
${ }^{5}$ Samuel P. Huntington, The Third Wave: Democratization in the Late Twentieth Century, vol. 4 (Norman: University of Oklahoma Press, 1993). pp. 65-66.

6 UNESCO Institute for Statistics, "UIS Statistics in Brief: Education profile - Egypt," United Nations Educational, Scientific and Cultural Organisation, 2012, Available Online at:

http://stats.uis.unesco.org/unesco/TableViewer/document.aspx?Reportld=121\&IF_Language=en\&BR_Country=2200. (Accessed: 22 November 2013)

7 Mark Rodenbeck, "Holding its breath: A special report on Egypt," (London: The Economist, 2010), p. 10.

${ }^{8}$ Francis Fukuyama, "The Middle-Class Revolution," The Wall Street Journal, 2013, Available Online at: http://online.wsj.com/news/articles/SB10001424127887323873904578571472700348086. (Accessed: 11 February 2014)
} 
state, ${ }^{9}$ with government spending on education in decline during the final years of the Mubarak regime; from 19.5 percent in 2002 to 11.5 percent in $2006 .{ }^{10} \mathrm{In}$ order to fill the gap left by the state education system, a vast network of private tutors emerged, with one report claiming that this network accounted for 1.6 percent of GDP. ${ }^{11}$

\section{Growth of the Middle Class}

Modernisation theorists argue that the growth of the middle class comes with mounting aspirations for greater political participation, which places pressure on authoritarian regimes to democratise. ${ }^{12}$ The expansion of the middle class in Egypt began during the Nasser era, when land reform policies and subsidies for education, food and housing lessened the sharpness in disparity between the rich and poor. Under Mubarak, the expansion of public education in Egypt, particularly at the tertiary level, as well as promises of public sector employment to all university graduates, led to further growth of the middle class. Somewhat paradoxically, the middle class emerged as one of the key groups during the revolution, despite traditionally being 'courted' by the regime. ${ }^{13}$ This goes against much of the scholarship on the nature of the middle class, who are generally characterised as being individualistic and inward-looking, ${ }^{14}$ and not prone to revolutionary uprising. Kandil attempts to unpick the reasons why the middle class became dissatisfied in Egypt. He argues that the regime had reduced the importance of the middle class, with neoliberal policies shrinking the size and roll of the public sector. The middle class' prospects were looking increasingly bleak if Mubarak's son Gamal was to inherit the presidency, particularly those of the younger middle class members with university degrees, ${ }^{15}$ as privatisation policies would only further shrink the public sector. In addition, the middle class had become frustrated at the regime's inability to provide for their basic needs, including free, quality education, investment in services, and a fair redistribution of wealth. ${ }^{16}$

\section{Trade, Investment and Tourism}

Egypt had also experienced an increase in international trade, investment and tourism. According to modernisation theorists, economic development and the associated contact with the international

\footnotetext{
${ }^{9}$ Richard Shediac, Samer Bohsali, and Hatem Samman, The Bedrock of Society: Understanding and Growing the MENA Region's Middle Class, (Dubai, UAE: Booz and Company Inc., 2012), p. 18.

10 Daniela Pioppi et al., "Transition to What: Egypt's Uncertain Departure from Neo-Authoritarianism," in Mediterranean Paper Series 2011 (Washington DC: The German Marshall Fund of the United States, 2011), p. 17.

${ }^{11}$ Rodenbeck, "Holding its breath," p. 10.

12 Huntington, The Third Wave, 4: pp. 65-66.

${ }^{13}$ Hazem Kandil, "Why did the Egyptian Middle Class March to Tahrir Square," Mediterranean Politics 17, no. 2 (2012): p. 197.

14 Ibid., p. 198.

15 Ibid., pp. 211-12.

16 Ibid., p. 212.
} 
community through trade, foreign investment and tourism means non-democratic states are exposed to democratic governance and the ideals exhibited by other states in the international arena. Egypt had experienced contact with the global community through trade and investment since Sadat pursued his policy of infitah, which exposed the Egyptian state to foreign capital. ${ }^{17}$ Mubarak also pursed policies to liberalise foreign access to the Egyptian economy, which was largely influenced by Prime Minister Ahmed Nazif, and received widespread support from both the IMF and the World Bank. ${ }^{18}$ Between 2004 and 2007, foreign investment in Egypt tripled. ${ }^{19}$ Following a similar path to India, Egypt began to develop 'enterprise zones' for the outsourcing of internet technologies in particular, which took "advantage of the language skills of its educated population and its proximity to Europe." ${ }^{20}$ In 2010, both Microsoft and Vodafone had taken up this opportunity and invested in Egypt. Egypt had also signed numerous trade agreements, particularly since it joined the WTO in 1995. Egypt was also a popular international tourist destination, which provided a significant income. Tourism was worth US\$13 billion in 2010, accounting for 11.5 percent of GDP. ${ }^{21}$

\section{Democratic Values and Attitudes}

Modernisation theorists also focus on the impact of economic development on the values and attitudes held by people in society. The factors discussed above, including increasing education, a growing middle class, and exposure to international society, work to alter people's values and attitudes. Welzel and Inglehart are proponents of these ideas, arguing the economic development works to redefine people's "mass liberty aspirations" for democratic change. ${ }^{22}$ These measures of modernisation are less tangible than the other aspects discussed earlier, and are therefore more difficult to measure. However, we can see evidence of Egyptians' changing attitudes through the Arab Barometer study, which measures people's responses on a number of issues, including their attitudes about democracy. In a similar vein, the World Values Survey measures people's values and their impact on political and social life. The results of these surveys provides us with evidence that

\footnotetext{
${ }^{17}$ Karen Pfeifer, "Economic Reform and Privatisation in Egypt," in The Journey to Tahrir: Revolution, Protest, and Social Change in Egypt, ed. Jeannie Sowers and Chris Toensing (London: Verso, 2012), p. 205. 
popular support for democracy is widespread in Egypt, and the wider Middle East, ${ }^{23}$ and will be discussed in more depth in the next chapter.

\section{Conclusion on Modernisation Theory}

Despite being able to observe the development of factors related to modernisation in Egypt prior to the revolution, the Egyptian case does not entirely support this theory. Modernisation theory primarily focuses on the structural conditions that predispose a country to make a transition to democracy, as opposed to the mass mobilisation of people to push for democracy through revolution, which was the case in Egypt. Critics of modernisation theory cite its passive nature, arguing that it excludes the key role of people in bringing about democratisation. ${ }^{24}$ This criticism holds in the Egyptian case, where the involvement of civil society and the general public were pivotal. In the years leading up to the revolution, Egypt did demonstrate some of the risk factors which modernisation theorists have identified as preconditions for a transition to democracy, however democratisation has not eventuated. This reveals a weakness of modernisation theory, namely that it fails to account for cases of regime breakdown, and the major issues facing countries who are attempting transition. These can include significant and debilitating societal divisions surrounding the nature and direction of transition, as well as the difficulty of maintaining order and the rule of law in what is often a case of complete state breakdown. These challenges have characterised the post-revolution environment in Egypt, and it is looking increasingly unlikely that democracy will be embraced by the new regime. Instead, Egypt is experiencing a reversion to authoritarianism.

\section{Economic Inequality}

Economic inequality in Egypt has been labelled as one of the key 'causes' of the revolution in both the media and academic work. Hibbard and Layton label Egypt as a "plundered country," with a small class of crony capitalists who benefitted from Mubarak's economic policies at the expense of wider society. ${ }^{25}$ High level corruption was pervasive in Egypt, and highly visible. ${ }^{26}$ In 2010, Egypt ranked $98^{\text {th }}$ on Transparency International's Corruption Perceptions Index, with a score of 3.1. ${ }^{27}$ High levels of corruption can be observed in Egypt throughout the 1990s and had become, as Fahmy

\footnotetext{
${ }^{23}$ Amaney Jamal and Mark Tessler, "The Democracy Barometers: Attitudes in the Arab World," Journal of Democracy 19, no. 1 (2008): p. 97.

${ }^{24}$ Adam Przeworski and Fernando Limongi, "Modernization: Theories and Facts," World Politics 49, no. 2 (1997): p. 177.

${ }^{25}$ Scott Hibbard and Azza Salama Layton, "The origins and future of Egypt's revolt," Journal of Islamic Law and Culture 12, no. 3 (2010): p. 205.

${ }^{26}$ Hazem Kandil, Soliders, Spies, and Statesmen: Egypt's Road to Revolt (London: Verso, 2012). pp. 211-16.

27 Transparency International, "Corruption Perceptions Index 2010," Transparency International, 2010, Available Online at: http://www.transparency.org/cpi2010/results. (Accessed: 16 July 2013)
} 
identifies, "deeply rooted, institutionalised, and systematised in society." ${ }^{28}$ Mubarak and members of his family reportedly kept billions of dollars in their personal accounts. ${ }^{29}$ Particularly interesting to note is the rise to wealth of Ahmed Ezz, a close friend of Gamal Mubarak, who managed to monopolise almost 65 percent of the Egyptian steel market in the space of a few years. ${ }^{30}$

Inflation and a rise in the price of food and other staples also reportedly fuelled discontent amongst Egyptians. The tradition of state subsidised bread, among other staples, had been used as a means to ensure societal acquiescence towards the regime since the time of Nasser. ${ }^{31}$ As I discussed in Chapter Two, a sharp increase in global food prices in 2008 caused widespread protest in Egypt, where bread prices rose by 37 percent in $2007 .^{32}$ Immediately prior to the Egyptian Revolution, the FAO declared a global food crisis, with prices surpassing even 2008 levels. ${ }^{33}$ The price of bread rose considerably in Egypt, as did the price of fuel and other staples. Statistics released by the Egyptian Central Bank show that the year-over-year rise in the cost of food and beverages was 18.5 percent for the 2009/2010 fiscal year, which significantly exceeds the overall rise in the Consumer Price Index of 10.7 percent. $^{34}$

Many Egyptians had also become disillusioned with the high levels of unemployment, which sat on average between 10 and 20 percent in the years prior to Mubarak's removal..$^{35}$ This was a particular grievance amongst the youth demographic. In Egypt, high fertility rates produced a significant 'youth bulge,' with 25 percent of the Egyptian population aged between 18 and $30 .^{36}$ In 2010, it was estimated that 90 percent of Egypt's unemployed were under the age of $30 .{ }^{37}$ These unemployed youths were referred to as hittistes in colloquial Arabic, meaning 'those who lean up against walls. ${ }^{\prime 38}$ Frustration at the lack of job prospects, as well as extended periods of 'waithood' - during which young people simply waited for their lives to begin, living with their family as they were unable to

\footnotetext{
${ }^{28}$ Hazem Fahmy, "An Initial Perspective on "The Winter of Discontent": The Root Causes of the Egyptian Revolution," Social Research 79, no. 2 (2012): pp. 363-64.

${ }^{29}$ Ali Sarihan, "Is the Arab Spring in the Third Wave of Democratisation? The Case of Syria and Egypt," Turkish Journal of Politics 3, no. 1 (2012): pp. 75-76; Hibbard and Layton, "The origins and future of Egypt's revolt," p. 205.

${ }^{30}$ Fahmy, "An Initial Perspective on "The Winter of Discontent"," pp. 364-65.

${ }^{31}$ Annia Ciezadlo, "Let Them Eat Bread: How Food Subsidies Prevent (and Provoke) Revolutions in the Middle East," in The New Arab Revolt, ed. The Council on Foreign Relations (New York: The Council on Foreign Relations, 2011), p. 230.

32 Ibid., pp. 232-33.

33 Ibid., p. 233.

${ }^{34}$ Laurel E. Miller et al., Democratization in the Arab World: Prospects and Lessons from Around the Globe (Santa Monica, CA: RAND Corporation, 2012). p. 87.

35 George Joffé, "The Arab Spring in North Africa: Origins and Prospects," The Journal of North African Studies 16, no. 4 (2011): p. 509.

${ }^{36}$ United Nations Development Programme and the Institute of National Planning Egypt, "Egypt Human Development

Report 2010," (United Nations Development Programme, 2010), p. 35.

37 Ibid., p. 6.

${ }^{38}$ Ellen Knickmeyer, "The Arab World's Youth Army," Foreign Policy, 2011, Available Online at: http://www.foreignpolicy.com/articles/2011/01/27/the arab world s youth army?page=0,0. (Accessed: 17 July 2013)
} 
marry or own property ${ }^{39}$ - contributed to the fuelling of unrest in Egypt, as well as the wider region. ${ }^{40}$

Poverty is cited as a common reality for many Egyptians. Beginning in the 1990s, a programme of neo-liberal economic reform promoted by the IMF was favoured by Mubarak. Under the 'Washington consensus' programme, encouraging signs of growth could be observed, with Egypt's annual economic growth rate between 1990 and 2005 sitting at an average of 4.2 percent. This rose to 6 percent in 2006 and 2007 in the build up to the 2008 global financial crisis. ${ }^{41}$ However, despite improvements on a macroeconomic level, this did not translate into positive gains for ordinary Egyptians on a microeconomic level. ${ }^{42}$ Despite GDP per capita figures along the lines of US\$6200 in 2010,43 a significant proportion of the population lived on US\$1 per day; the poverty rate rising from 20 percent in 2000 to 25 percent in $2009 .{ }^{44}$ Poverty was more prolific in rural areas, with rates double that of urban areas. ${ }^{45}$ The increase of people living in poverty in Egypt occurred despite a growth in GDP per capita of 5.3 percent in 2008, 2.9 percent in 2009, and 3.3 percent in $2010 .{ }^{46}$ Ordinary Egyptians' frustration at the lack of any trickle down benefits of economic growth was compounded by a significant absence of any political reform under Mubarak. ${ }^{47}$

\section{A Questionable Explanation}

Looking at economic inequality and the associated issues of corruption, unemployment, inflation and poverty as direct causes of Egypt's Revolution raises a number of puzzling questions. Despite being painted in a dire light, economic inequality in Egypt was not as pervasive during the years prior to 2011 as many accounts claim. In fact, World Bank data shows that Egypt's Gini coefficient ${ }^{48}$ was in decline during the last decade of Mubarak's rule - dropping from 36.1 percent in 2000 to 30.7 percent in $2009^{49}$ - and had been in constant decline over the past 60 years. ${ }^{50}$ Inequality between

\footnotetext{
39 United Nations Development Programme and the Institute of National Planning Egypt, "Egypt Human Development Report 2010," p. 3.

${ }^{40}$ Steve Hess, "From the Arab Spring to the Chinese Winter: The institutional sources of authoritarian vulnerability and resilience in Egypt, Tunisia, and China," International Political Science Review 34, no. 3 (2013): p. 257.

${ }^{41}$ Robert L. Tignor, Egypt: A Short History (Princeton, NJ: Princeton University Press, 2010). p. 289.

42 Joffé, "The Arab Spring in North Africa," p. 509.

${ }^{43}$ Sarihan, "Is the Arab Spring in the Third Wave of Democratisation?," p. 75.

44 Miller et al., Democratization in the Arab World: p. 86.

${ }^{45}$ Sufyan Alissa, "The Political Economy of Reform in Egypt: Understanding the Role of Institutions," (Washington DC: The Carnegie Middle East Centre, 2007), p. 13.

46 Hess, "From the Arab Spring to the Chinese Winter," p. 256.

${ }^{47}$ Richard N. Hass, "Reflections on the Revolution in Egypt," in The New Arab Revolt, ed. The Council on Foreign Relations (New York: The Council on Foreign Relations, 2011), p. 115.

48 The Gini coefficient is a measure of the average distance between incomes in a particular country.

49 Paolo Verme et al., "Inside Inequality in the Arab Republic of Egypt: Facts and Perceptions Across People, Time, and Space," (Washington DC: The World Bank, 2014), p. 1.

50 Ibid., p. 2.
} 
urban and rural areas was consistent with global patterns, and was not huge by international standards. ${ }^{51}$ In fact, in a comparative sense, Egypt was characterised by lower levels of income inequality than countries with similar levels of GDP per capita, such as Georgia, Guatemala, and China. Even the US had a higher Gini coefficient than Egypt. Therefore, if inequality is indeed a 'cause' of revolution, Egypt does not appear to be the most likely candidate for widespread societal unrest.

Studies in the years since 2011 have disputed claims that economic inequality was a 'cause' of Egypt's Revolution. A 2014 World Bank report illustrates the discrepancy between measurements of monetary inequality in Egypt, measured by household expenditure surveys, and the perception of income inequality reported by people in values surveys. ${ }^{52}$ The World Bank report suggests that people's perceptions of economic inequality led them to overstate the situation in Egypt. The report provides a number of explanations in an attempt to untangle this paradox. First, Egyptians' expectations were altered by economic growth and volatility. Over the decade prior to Mubarak's removal, Egypt experienced growth in GDP, but also increased volatility, particularly in the prices of everyday staples. People therefore became more concerned about these issues, which subsequently altered their economic expectations. Second, people became more socially and economically aware, which in turn altered their perceptions of their relative position with regard to a number of key variables, including life satisfaction, trust and freedom, and inequality aversion. This final variable is particularly interesting to note, with results from both the 2000 and 2008 World Values Survey suggesting that subjective aversion to inequality in Egypt became more intense. ${ }^{53}$ Third, GDP did not have a noticeable trickle-down effect to individual households, and many experienced a decline in absolute welfare, which had a significant impact on perceptions of income inequality amongst ordinary Egyptians. Miller and others summarise succinctly the economic insecurity felt by many Egyptians, arguing that "the benefits of economic growth were largely captured by a small number of "haves" and... the living standards of less well-to-do Egyptians eroded." 54 Finally, Egypt's lack of democratic institutions and processes may have intensified inequality aversion amongst the general population. A further factor to note is the change in reference groups which occurred. The expansion of social media networks and subsequent transnational expansion of the participants in the World

\footnotetext{
51 Ibid., p. 53.

52 Ibid., p. 1.

53 Paolo Verme, "Top Incomes and the Measurement of Inequality in Egypt," The World Bank, 2013, Available Online at: http://blogs.worldbank.org/developmenttalk/top-incomes-and-measurement-inequality-egypt. (Accessed: 23 March 2013) 54 Miller et al., Democratization in the Arab World: pp. 85-86.
} 
Values Survey altered people's aspirations and expectations, and their general self-assessment of their status in society. ${ }^{55}$

The World Bank report also notes that the mismatch between perceptions of welfare and actual welfare increased in Egypt over the last decade. ${ }^{56}$ Hlasny and Verme attempt to explain this mismatch between fact and perception. After ruling out that the measurement of inequality in Egypt was skewed by the distribution of top incomes, the authors claim that perceptions of inequality have mattered more for those attempting to explain the Egyptian Revolution than reality. ${ }^{57}$ This is not to say that inequality was not an issue in Egypt, but perhaps the real issue lay in the inequality of other dimensions - such as opportunities, rights, aspirations and values. ${ }^{58}$ However, during the Egyptian Revolution, the perceived issue of income inequality, as well as the linking of inequality to the Mubarak regime, was one of the major factors people played on in order to build momentum for the demonstrations, and it proved particularly persuasive and effective. The same argument applies when considering levels of corruption, inflation and poverty. On a global scale, Egypt under Mubarak was by no means the most corrupt, with the highest levels of inflation or poverty. For example, immediately prior to the revolution, Egypt's placing of $98^{\text {th }}$ on Transparency International's Corruption Perceptions Index ranked it on par with both Mexico and Burkina Faso; neither of whom experienced a revolution and regime breakdown. Instead, people's perceptions of corruption, inflation and poverty were conflated, and this proved more important in shaping their response to the situation than reality.

Unemployment proves the exception when considering people's perceptions of their economic position. As I discussed in Chapter Two, levels of unemployment in Egypt prior to the revolution had reached 10 percent, with a significant number of unemployed aged between 18 and 30, many of whom were university educated..$^{59}$ The decade prior to the revolution also saw a deterioration in employment quality, with the majority of jobs created between 1998 and 2006 in the informal economy. Such positions were characterised by low wages, a lack of job security, and were often entered into without formal contracts. ${ }^{60}$

\footnotetext{
55 Verme et al., "Inside Inequality in the Arab Republic of Egypt," pp. 96-97.

56 Ibid., p. 97.

57 Vladimir Hlasny and Paolo Verme, "Top Incomes and the Measurement of Inequality in Egypt," (The World Bank, 2013), p. 29.

58 Ibid., p. 30.

59 Hess, "From the Arab Spring to the Chinese Winter," p. 257.

60 Pioppi et al., "Transition to What," p. 15.
} 
Theorists provide a counter argument to those who stress inequality and the influence it has on transitions, arguing that highly equal societies are not likely to experience transition either, as economic stability will encourage the preservation of the status quo. ${ }^{61}$ However, this claim only holds true if citizens decide to put economic equality above all else, as authoritarian regimes are likely to exhibit a number of other characteristics that do not satisfy their citizens, such as restrictions on free speech, expression, and political participation. From observing the case of Egypt, we can see that inequality, as well as corruption, inflation, unemployment and poverty, were important for the upsurge of protest. This is regardless of whether these were actual material issues, or simply perceived to be so. This suggests that Egypt had reached a tipping point, where rising aspirations amongst ordinary Egyptians met and compounded middling levels of economic issues.

\section{Economic Crisis}

In the literature on economic theories of transition, scholars claim that periods of economic crisis have the potential to destabilise authoritarian regimes, as these regimes lack the legitimacy and effectiveness to bounce back from periods of economic recession. ${ }^{62}$ During the global financial crisis, Egypt did not experience a major economic downturn, with GDP in fact growing during the economically fraught years of 2008, 2009 and 2010. Growth had slowed in the years prior to the revolution but despite this, as Hess identifies, Egypt's economic situation was "not akin to the kind of deep economic crises that have typically destabilised authoritarian regimes." ${ }^{63}$ This lends weight to the argument I discussed in the previous section that perception was important in shaping people's understanding of the economic situation in Egypt. A more pertinent explanation is that many Egyptians felt a general sense of disillusionment with the economy and the economic opportunities available to them, which was not in line with the material reality of the situation. This was compounded by a decrease in remittances during the global financial crisis, which affected the position of many ordinary Egyptians, however only had a minimal impact at the macro level. ${ }^{64}$

In the post-revolution space, the on-going instability in Egypt has had an impact on the economy. Political uncertainty has translated into economic uncertainty, with investors losing confidence in the market. As well as this, security concerns have meant the tourism industry, which employs many

\footnotetext{
${ }^{61}$ Acemoglu and Robinson, Economic Origins of Dictatorship and Democracy: p. 38.

62 Linz and Stepan, Problems of Democratic Transition and Consolidation: p. 79.

${ }^{63}$ Hess, "From the Arab Spring to the Chinese Winter," p. 256.

64 Pioppi et al., "Transition to What," p. 16.
} 
Egyptians and makes up approximately 10 percent of GDP, has declined. ${ }^{65}$ These factors pose an ongoing economic challenge for Egypt.

\section{Conclusion}

Despite being widely cited by both media commentators and academics as one of the key factors behind the revolution, economic explanations in fact garner less support from the Egyptian case than some of the other explanations this thesis has examined. Analysis in this chapter has focused on Egypt alongside theories of economic modernisation, inequality and crisis. Despite being able to observe the development of factors related to modernisation prior to 2011, such as increasing education levels, an expanding middle class, increasing international investment, trade and tourism, and a change in values and attitudes, democracy has not emerged in Egypt. This reveals a weakness of modernisation theory, which fails to consider cases of regime breakdown, and the major issues which often emerge, including stark societal divisions and challenges associated with state breakdown. In the post-revolution space we are yet to observe any significant progress towards democracy, and are instead witnessing a reversion towards authoritarianism.

Modernisation theory does not provide a useful framework for explaining the breakdown of a regime in general, but theories relating to economic inequality and crisis do. However, the Egyptian case does not lend a great deal of support to these arguments either. Despite factors such as inequality, corruption and poverty being pinned as some of the key causes of the revolution, further analysis reveals that in fact people's perceptions of these factors instead proved more powerful motivators than their material reality. Levels of inequality had in fact decreased in the years prior to the revolution, and economic crisis was not at the level deemed necessary for regime change. However, perceptions of economic inequality and hardship proved enough to push people to demand that the Mubarak regime go, along with other factors discussed elsewhere in this thesis, such as police brutality, and a lack of political participation. In February 2011 Egypt had reached a tipping point, where rising aspirations amongst ordinary Egyptians met and compounded the middling levels of economic inequality and other issues that Egypt exhibited, creating an environment that was ripe for revolution. However, as we have seen over the past three years, this environment has not been conducive to democratisation.

65 Brad Plumer, "The economic roots of Egypt's crisis," The Washington Post, 2013, Available Online at: http://www.washingtonpost.com/blogs/wonkblog/wp/2013/07/03/the-economic-roots-of-egypts-crisis/. (Accessed: 23 November 2013) 


\section{Chapter Seven \\ Religious and Cultural Factors and the Egyptian Revolution}

\section{Introduction}

Arguments relating religion and culture to the prospect of democracy are apparent throughout the literature on democratisation. In Chapter One, I discussed instances where scholars have made the case that democracy and Islam are incompatible, arguing that there is a much higher correlation between democracy and Christianity than there is with Islam, ${ }^{1}$ and that cultural aspects of Muslimmajority societies foster an environment hostile to democracy. ${ }^{2}$ These arguments are not supported by the Egyptian case, where other factors aside from religion and culture better explain the persistence of authoritarianism under Mubarak. The responses of Egyptians to the Arab Barometer study and the World Values Survey further illustrate the lack of utility behind such arguments. However, in the post-revolution space, democracy is facing some challenges from the Islamist agenda of the Muslim Brotherhood, though these obstacles are not necessarily insurmountable.

\section{Islam is Incompatible with Democracy}

A number of scholars have attempted to explain the "democracy gap" ${ }^{3}$ in the Middle East using arguments based on religion and culture. The various arguments claim that Islamic values run counter to those required for democracy, which include respect for individual responsibility, inclusion, civic participation, and tolerance. ${ }^{4}$ Instead, participation and the rights of individuals, as well as the rule of law and secularism, are "profoundly alien to the Muslim political tradition," ${ }^{5}$ and Islam also "fosters a blind acceptance of authority." ${ }^{6}$ Fish argues that the 'democracy deficit' in Islamic countries is explained by the subordination of women. ${ }^{7}$ After first ruling out that the lack of democratic regimes in the Muslim world can be explained by an increased propensity towards

\footnotetext{
${ }^{1}$ Samuel P. Huntington, The Third Wave: Democratization in the Late Twentieth Century, vol. 4 (Norman: University of Oklahoma Press, 1993). p. 73.

2 M. Steven Fish, "Islam and Authoritarianism," World Politics 55, no. 01 (2011).

${ }^{3}$ Rex Brynen et al., Beyond the Arab Spring: Authoritarianism and Democratisation in the Arab World (Boulder, Colorado: Lynne Rienner Publishers, Inc., 2012). p. 95.

${ }^{4}$ Laurel E. Miller et al., Democratization in the Arab World: Prospects and Lessons from Around the Globe (Santa Monica, CA: RAND Corporation, 2012). p. 44.

${ }^{5}$ Elie Kedourie, Democracy and Arab Political Culture (London: Frank Cass Publishers, 1994). p. 6.

${ }^{6}$ Bernard Lewis, Islam and the West (Oxford: Oxford University Press, 1993). pp. 45-46.

${ }^{7}$ Fish, "Islam and Authoritarianism," p. 5.
} 
political violence, low levels of interpersonal trust, and heightened anti-secularism, ${ }^{8}$ Fish uses literacy rates and population sex ratios to illustrate his argument.

However, a number of scholars have put forward counter arguments to the claim that Islam and democracy are incompatible. Looking at the case of Jordan in 1997, Robinson argues that Islamist movements are not the "greatest threat to democratic transitions in the Middle East." ${ }^{9}$ Instead, Jordan's Muslim Brotherhood "proved themselves to be capable democrats, obeying the rules of the political game while parlaying their strength in society into a parliamentary plurality." ${ }^{10}$ Scholars have also related authoritarianism to other major world religions, arguing that both Catholicism and Confucianism have also at times been negatively correlated with democracy, however successful transitions to democracy have occurred in Latin America, Southern Europe and East Asia. ${ }^{11}$ As well as this we can observe successful democratic transitions in Muslim-majority Turkey, Indonesia and Bangladesh, as well as other countries with similar demographics. ${ }^{12}$ As Diamond makes clear, democracy became a global phenomenon as opposed to a "Western preserve" with the beginning of the 'third wave' of democratisation. ${ }^{13}$

\section{The Persistence of Authoritarianism under Mubarak}

The correlation between Islamic societies and authoritarianism lacks solid causation. Mubarak's 30 year reign in Egypt was not due to the religious or cultural features of Egyptian society. This is not to say that culture was irrelevant, as "cultural factors - rooted in history and social experience - help to shape how people think about themselves, the groups with which they identify, the nature of communication, and the value that people place on certain political processes and outcomes."14 However, cultural orientations were not the most important factor. Instead, we can observe more structural reasons as to why Mubarak held onto power for so long, which worked to "foster robust authoritarianism and especially a robust and politically tenacious coercive apparatus." ${ }^{15}$ These included foreign support for the regime to protect international interests, a tradition of Middle Eastern authoritarian states propping each other up through the Arab League, and the nature of rentierism in Egypt. Diamond is one such scholar who takes a more structural approach to the

\footnotetext{
8 Ibid., pp. 16-24.

${ }_{9}^{9}$ Glenn E. Robinson, "Can Islamists be Democrats? The case of Jordan," Middle East Journal 51, no. 3 (1997): p. 387.

10 Ibid., p. 386.

${ }^{11}$ Eva Bellin, "The Robustness of Authoritarianism in the Middle East: Exceptionalism in Comparative Perspective," Comparative Politics 36, no. 2 (2004): p. 141.

12 L. Blaydes and J. Lo, "One man, one vote, one time? A model of democratization in the Middle East," Journal of Theoretical Politics 24, no. 1 (2011): p. 114.

13 Larry Diamond, "Democracy's Third Wave Today," Current History 110, no. 739 (2011): p. 299.

${ }^{14}$ Brynen et al., Beyond the Arab Spring: p. 96.

${ }^{15}$ Bellin, "The Robustness of Authoritarianism in the Middle East," p. 152.
} 
persistence of authoritarianism in Egypt. He discusses the 'coils of geopolitics,' and the degree to which these reinforced Mubarak's position in Egypt. First, major international powers, particularly the US, traditionally propped up Mubarak, and other Middle Eastern dictators, to protect their interests in the region. ${ }^{16}$ These interests were largely to do with maintaining a reliable supply of oil, and countering the threat of radical Islam, ${ }^{17}$ as well as ensuring peace with Israel. Second, the Arab League provided a forum for the member states to "reinforce one another in their authoritarianism and their techniques of monitoring, rigging, and repression." 18

The third reason for Mubarak's longevity had to do with rentierism. Rentier states depend heavily on income from 'rents' to keep their economies afloat, much of which is essentially unearned income. ${ }^{19}$ In the Middle East, states received rentier income largely from oil and gas reserves, of which Egypt had little of; accounting for only 1 percent of GDP. ${ }^{20}$ However, other sources of rentier income included Suez Canal tariffs and military assistance from the US. Tariffs collected from the use of the Suez Canal totalled an average of US\$5 billion per annum, ${ }^{21}$ equating to 10 percent of total state revenue. $^{22}$ Egypt also received a significant amount of military aid from the US each year. In 2010, Egypt received US\$1.3 billion in military assistance, making it the second biggest receiver of US military aid after Israel. ${ }^{23}$ Rentier income generally flowed directly into state coffers, meaning the government only required low levels of taxation from its citizens, which in turn theoretically kept them placated.

Other explanations for the persistence of authoritarianism under Mubarak have been discussed elsewhere in this thesis. They included, first, Mubarak's tradition of electoral authoritarianism. Elections served as a tool to consolidate the power of the regime, largely through easing any internal conflict amongst regime elites, providing intelligence on the performance and loyalty of NDP members, allowing Mubarak to formally institutionalise his dominance, and providing a means to hide corrupt activities and provide an outward display of democracy to the international community. ${ }^{24}$ Second, regime repression, particularly at the hands of the internal security apparatus,

\footnotetext{
${ }^{16}$ Larry Diamond, "Why Are There No Arab Democracies?," Journal of Democracy 21, no. 1 (2010): p. 101.

17 Bellin, "The Robustness of Authoritarianism in the Middle East," p. 148.

18 Diamond, "Why Are There No Arab Democracies?," p. 101.

19 Ibid., p. 97.

20 J. Craig Jenkins et al., "International Rentierism in the Middle East and North Africa, 1971-2008," International Area Studies Review 14, no. 3 (2011): p. 24.

${ }^{21}$ World Shipping Council,"Educational Resources: The Suez Canal," World Shipping Council, 2009, Available Online at: http://www.worldshipping.org/additional-resources/educational-resources. (Acessed: 18 July 2013)

22 Jenkins et al., "International Rentierism in the Middle East and North Africa, 1971-2008," p. 15.

23 Jeremy M. Sharp, "Egypt: Background and US Relations," (Congressional Research Service, 2013), p. 22.

${ }^{24}$ Lisa Blaydes, Elections and Distributive Politics in Mubarak's Egypt (New York: Cambridge University Press, 2011).
} 
encouraged people to remain acquiescent. It was not until this barrier of fear was broken, largely by the inspiring actions of nearby Tunisians, that Egyptians stood up against Mubarak.

\section{The Arab Barometer and World Values Survey}

Despite the persistence of authoritarianism under Mubarak, findings from international research efforts tell us that ordinary people in Egypt and the wider Middle East were not opposed to democracy. In fact, as Jamal discusses, the idea that Islam and democracy are "diametrically opposed categories" seems to be a reserve of Western academia. In the Arab world, support for democracy was just as high as it was for Islamism, and the two were often simultaneous. He states that:

[t]he discourse on the compatibility of Islam and democracy is quite vibrant and nuanced. From mosque sermons to newspaper columns, college campus speeches to coffee shop discussions, citizens of the Arab world view the tenets of Islam as inherently democratic. There is no distance between Islam and democracy. ${ }^{25}$

We can see evidence of this through values surveys, including the Arab Barometer and the World Values Survey. The Arab Barometer study measures people's responses on a number of topics, including attitudes about democracy, tolerance and respect for diversity, civil engagement and political participation, among others. Results published in the Journal of Democracy in 2006 suggested that democracy enjoyed widespread support in the Middle East; however the project did not look at Egypt specifically. ${ }^{26}$ A later publication in 2012 provides results from a more recent Arab Barometer survey, which did consider Egypt. A constant between both sets of results was that support for democracy in the Arab world is widespread (see Figure One), while new questions in the second round of surveys revealed that a significant majority of people "believe in racial tolerance, support having women in the workplace, and prefer having a range of politicians who espouse diverse political ideas;"27 all factors which go hand in hand with democratisation.

\footnotetext{
${ }^{25}$ Amaney A. Jamal, "Reassessing Support for Islam and Democracy in The Arab World? ," World Affairs 169, no. 2 (2006): p. 51.

${ }^{26}$ Amaney Jamal and Mark Tessler, "The Democracy Barometers: Attitudes in the Arab World," Journal of Democracy 19, no. 1 (2008): p. 97.

${ }^{27}$ Mark Tessler, Amaney Jamal, and Michael Robbins, "New Findings on Arabs and Democracy," Journal of Democracy 23, no. 4 (2012): p. 89.
} 


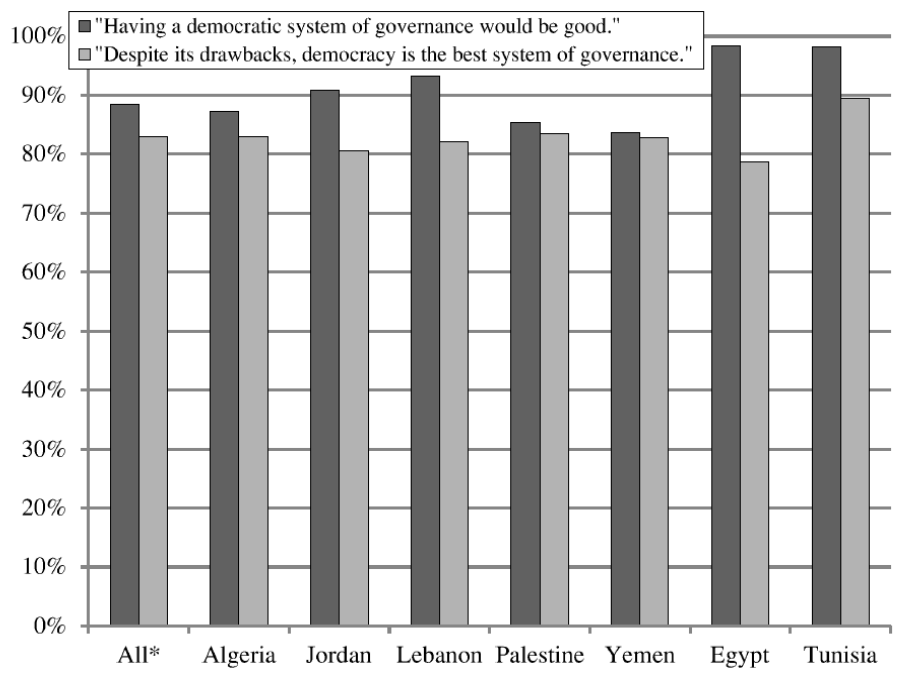

Figure One - Support for democracy

Mark Tessler et al., "New Findings on Arabs and Democracy," Journal of Democracy 23, no. 4 (2012): p. 91.

The World Values Survey is another social research project which collects information on people's changing values and the impact this has on social and political life. The range of values measured includes such issues as democracy, good governance and political participation, to environmental protection and subjective well-being. In a 2002 article, Tessler reported on the World Values Survey findings from Egypt. The results suggested overwhelming support for democracy, with 67.9 percent of respondents answering 'very good' when asked what they thought having a democratic government would be like, and 63.3 percent strongly agreeing that democracy, despite its problems, is better than any other form of government. ${ }^{28}$ Tessler's analysis also considered degrees of religiosity, and concluded that strong Islamic attachments have no significant influence on whether people are supportive of democracy or not. ${ }^{29}$ Further results from the World Values Survey, conducted in Egypt in 2008, reveal a similar picture. Seventy eight percent of respondents answered 'very good' when asked what they though having a democratic government would be like, and 69 percent answered that democracy was of absolute importance to them. ${ }^{30} \mathrm{~A}$ similar response rate can be observed in the most recent survey round, with 70 percent of respondents answering that having a democratic political system would be 'very good. ${ }^{31}$

\footnotetext{
${ }_{28} \mathrm{M}$. Tessler, "Do Islamic Orientations Influence Attitudes Toward Democracy in the Arab World? Evidence from Egypt, Jordan, Morocco, and Algeria," International Journal of Comparative Sociology 43, no. 3-5 (2002): p. 234.

29 Ibid., p. 243.

30 World Values Survey, "Integrated EVS/WVS 1981-2008 Variables," World Values Survey, 2008, Available Online at: http://www.wvsevsdb.com/wvs/WVSIntegratedEVSWVSvariables.jsp?Idioma=I. (Accessed: 14 February 2014)

${ }^{31}$ World Values Survey, "World Values Survey Wave 6: 2010-2014," World Values Survey, 2014, Available Online at: http://www.worldvaluessurvey.org/WVSOnline.jsp. (Accessed: 10 May 2014)
} 
However, when looking beyond the headline numbers that show overwhelming support for democracy amongst Egyptians, the World Values Survey reveals the persistence of a number of other values which are not particularly encouraging for democracy. For example, when asked if having a strong leader who does not have to bother with parliament and elections was a good thing, 71 percent of Egyptian respondents answered that this was 'very good' in the most recent survey round. ${ }^{32}$ Nevertheless, such factors have little connection with religious or cultural dispositions. Instead, as Inglehart identifies, this had more to do with variations in the 'solidity' of support for democracy, which is largely affected by a country's experience with democracy. ${ }^{33}$ Factors such as these may account for the persistence of authoritarianism under Mubarak, and lack of progress towards democracy in the post-revolution space.

\section{Reconciling Islam and Democracy in Post-Revolution Egypt}

In the years since the revolution, Egypt has already experienced a brush with Islamist-led democracy under President Morsi and the Muslim Brotherhood's Freedom and Justice Party, who emerged as the only viable candidate to take over from the SCAF. Despite the largely secular nature of Egypt's revolution, the Muslim Brotherhood is first and foremost an Islamist organisation. While rejecting radical Islam, perpetuated in an often violent fashion by militant groups such as al-Gama'a alIslamiyya and al-Jihad al-Islami, the organisation's central slogans are 'Islam is the solution,' 'the Islamic state,' and 'the enforcement of sharia;' all of which have remained unchanged since the Brotherhood's conception in the 1920s. ${ }^{34}$ These key tenets shone through during their year in power, despite the rhetoric during their election campaign that the Freedom and Justice Party was "committed to a modern state, democracy, women's rights, and national unity and insisted that it did not wish a monopoly of power or to dominate parliament." 35 For example, the constitution drafting process under Morsi's government was dominated by Islamists, and had a significant Islamic focus, declaring Islam as the state religion, and sharia as the main source of legislation. ${ }^{36}$

Morsi's removal by the military in July 2013 was partially due to concerns regarding the Islamist direction of the Morsi government, as well as wider issues surrounding the failure to meet some of the key demands of the revolution. Writing in 2012, Roy discusses how Egypt's Islamists, both the Muslim Brotherhood and the Salafis, will have to accept democracy, or they will find themselves

\footnotetext{
$32 \mathrm{lbid}$.

${ }^{33}$ Ronald Inglehart, "How Solid is Mass Support for Democracy - And How Can We Measure It?," PS: Political Science and Politics 36(2003): p. 52-53.

34 Theodor Tudoroiu, "Assessing Middle Eastern trajectories: Egypt after Mubarak," Contemporary Politics 17, no. 4 (2011):

p. 383.

${ }^{35}$ Brynen et al., Beyond the Arab Spring: p. 119.

${ }^{36}$ Said Amir Arjomand, "The Islam and Democracy Debate after 2011," Constellations 20, no. 2 (2013): p. 308.
} 
excluded in post-revolution Egypt. ${ }^{37}$ The changed social, religious, political and geostrategic nature of post-revolution Egypt will require the Islamists to "limit their supposed "hidden agenda" of establishing an Islamic state, [and] push them toward a more open and democratic way of governance, because therein lies their only chance to remain at the centre of political life."38 Proponents of the 'inclusion-moderation hypothesis' would argue that inclusion of Islamist groups in the political process is a positive thing, as it will have a moderating effect on their positions and beliefs. ${ }^{39}$ However, as Roy makes clear in a later article, an Islamist-led democracy in Egypt is unlikely to look like a traditional Western-conceived liberal democracy. The Muslim Brotherhood is the product of decades of repression, which has made them "both cautious and vindictive.... The Brotherhood will appoint their militants and cronies to government posts, support censorship on grounds of "morality," and balk at a free and independent press." ${ }^{\text {"0 }}$ As well as not appearing necessarily liberal, a Muslim Brotherhood-led government is hardly likely to embrace secularism either; Roy arguing that they will more than likely move towards a "Muslim democracy"... that endorses nationalism and recasts Islamic norms as moral and cultural values which appeal to a larger conservative constituency." ${ }^{41}$

These arguments aside, it is clear that the Muslim Brotherhood is an important actor in Egypt, with a long history and widespread popular support amongst many Egyptians. Writing at the time of the revolution in 2011, Wickham argues that no democratic transition in Egypt could succeed without the involvement of the Muslim Brotherhood. ${ }^{42}$ This has proved correct, considering the degree of violence and chaos that has characterised Egypt since the exclusion of the Muslim Brotherhood from the post-revolution political scene in mid-2013.

\section{Conclusion}

The above analysis reveals that religion and culture had little to do with the persistence of authoritarian rule under Mubarak, which can instead be explained by structural factors. Data from the Arab Barometer study and the World Values Survey also reveals that Egyptians, and the people of the wider Middle East, are not adverse to democracy. Instead, there has been longstanding support for democratic governance for at least the decade prior to Mubarak's ouster. In fact, as Hazran jubilantly states, the Egyptian Revolution has, "overturned the classic Orientalist argument"

\footnotetext{
37 Oliver Roy, "The Transformation of the Arab World," Journal of Democracy 23, no. 3 (2012): p. 7.

38 Ibid., p. 8.

39 Brynen et al., Beyond the Arab Spring: pp. 129-30.

40 Oliver Roy, "There will be no Islamist Revolution," Journal of Democracy 24, no. 1 (2013): p. 16.

$41 \mathrm{lbid}$.

${ }^{42}$ Carrie Rosefsky Wickham, "The Muslim Brotherhood After Mubarak," in The New Arab Revolt, ed. The Council on Foreign Relations (New York: The Council on Foreign Relations, 2011), p. 97.
} 
which reserves democracy to the realms of Western society. ${ }^{43}$ This may overstate the situation somewhat, as Egypt has not transitioned to democracy, and further analysis beyond headline indicators reveals widespread support for factors that are not considered aspects of a liberal democracy. However, this is not necessarily due to factors relating to religion and culture, and may be better explained by Egypt's lack of experience with democracy and the continued persistence of unrest in the years since 2011.

It appears that Islam and democracy are not irreconcilable. In a discussion of Tunisia since its uprising in 2010 - 2011, Stepan builds on his concept first introduced in 2000 of 'twin tolerations,' which could prove useful for the Egyptian case. 'Twin tolerations' has two components, as Stepan outlines:

The first toleration is that of religious citizens toward the state. It requires that they accord democratically elected officials the freedom to legislate and govern without having to confront denials of their authority based on religious claims - such as the claim that "Only God, not man, can make laws." The second toleration is that of the state towards religious citizens. This type of toleration requires that laws and officials must permit religious citizens, as a matter of right, to freely express their views and values within civil society, and to freely take part in politics, as long as religious activists and organisations respect other citizens' constitutional rights and the law. ${ }^{44}$

Comparing Tunisia to Egypt, Stepan notes that the latter has been unable to make the same progress as Tunisia in the post-revolution space. This has been due to the lack of dialogue between Islamist and secular forces, and a delay in recognising and accepting the 'twin tolerations,' among a number of other factors, particularly pertaining to the nature of Egypt's military establishment, which is vastly different from Tunisia's. ${ }^{45}$

Despite the challenges of building a democracy in a Muslim-majority country such as Egypt, it is by no means insurmountable. As Brynen discusses, religious traditions are malleable, and are therefore likely to shift to accommodate the changing nature of Egyptian society. ${ }^{46}$ Egypt has already had an experience of an Islamist-led government in the post-revolution space, which was subsequently removed. However, the Muslim Brotherhood remains an influential organisation with a wide base of support, and we are unlikely to see them permanently side-lined from any future political arrangement. That being said, an Islamist-led democracy in Egypt is unlikely to mirror Western conceptions of liberal democracy, and could perhaps operate along the 'twin tolerations' model akin to Tunisia's.

\footnotetext{
43 Yusri Hazran, "The Arab Revolutions: A Preliminary Reading," Middle East Policy 19, no. 3 (2012): p. 116.

${ }^{44}$ Alfred Stepan, "Tunisia's Transition and the Twin Tolerations," Journal of Democracy 23, no. 2 (2012): pp. 89-90.

45 Ibid., pp. 94-95.

${ }^{46}$ Brynen et al., Beyond the Arab Spring: p. 99.
} 


\section{Conclusion}

\section{Summary}

The events that have transpired in Egypt over the last three years have changed the face of global history, as well as challenged the scholarship which considers transitions away from authoritarianism and towards democracy. This thesis has attempted to explore the utility of the existing transitions literature for explaining the Egyptian case, as well as why three years after the 2011 revolution, Egypt remains firmly entrenched under authoritarian rule, with little in the way of progress towards democracy. This situation illustrates the non-linear nature of the transitions process which, despite claims by some that democratisation can be 'crafted, ${ }^{1}$ is in fact a much more complex and fraught process.

Analysis throughout this thesis has revealed that theories of authoritarian breakdown garner more support from the Egyptian case than theories of democratisation. As I discussed in Chapter Four, theories relating to the diffusion of revolution across state borders proved pivotal for explaining the upsurge of protest in Egypt in early 2011, and further afield. The Tunisian example proved a powerful motivator for Egyptians, who consciously borrowed revolutionary tools from their Tunisian counterparts. The diffusion of protest was assisted by social media technologies, which provided a forum for organisation, communication, and the sharing of powerful images and messages. However, diffusion through both traditional means and social media platforms has not resulted in democratisation in Egypt.

In Chapter Four I also considered international influences on the Egyptian Revolution, and found that while international democracy promotion efforts by the US and the EU had some impact in Egypt, this was by no means the most important factor. In fact, it is difficult to quantify the effect that international democracy promotion efforts had in Egypt, which suggests that they have been almost negligible. On the other hand, it is easy to measure stability promotion in Egypt, particularly from the US. This suggests that stability and security concerns were prioritised over democracy promotion in order to protect international strategic interests. Additionally, it is important not to treat democracy promotion as simply a one way transaction, as we can see evidence of Egyptian revolutionaries attempting to seek their own learning from international sources.

\footnotetext{
${ }^{1}$ Giuseppe Di Palma, To Craft Democracies: An Essay on Democratic Transitions (Oxford, England: University of California Press, 1990).
} 
In Chapter Five I discussed theories which consider the role of actors in the transition process. Elite actors and civil society groups had an influence on both the timing and nature of Egypt's Revolution. The decision by the military to side with the demonstrators during the 2011 revolution provided the various civil society groups with the space to demonstrate, and removed the element of fear that they would be met with military resistance. However, much of the initial momentum for revolution stemmed from Egypt's active civil society movement. Groups such as the April 6 Movement, Kefaya, and "We Are All Khaled Said" played a pivotal role in organising demonstrations, which drew in participants from a wide cross section of Egyptian society. Despite Egypt's active civil society movement, which played such a crucial role in bringing down Mubarak, democracy has not eventuated. This can largely be explained by the authoritarian stance of the military since the revolution, which has removed the military as an actor with which civil society groups could ally themselves with in the post-revolution space. As well as this, Egyptian civil society has proved unable to capitalise on the momentum it garnered during the revolution, and translate this into an organised political framework. This has meant civil society has remained largely excluded from the political process since Mubarak's ouster, with the military emerging as the most powerful actor following the side-lining of the Muslim Brotherhood in mid-2013. This typifies 'rotten door' or 'tipping point' transitions, ${ }^{2}$ where initial success is achieved quickly and often spectacularly. However, lasting change is difficult without deeper structural shifts, and results are often disappointing.

Economic theories were the focus of Chapter Six, including arguments surrounding modernisation, economic inequality and crisis. Despite being pinned as one of the key 'causes' of the Egyptian Revolution, economic arguments in fact garner less support from the Egyptian case than many popular accounts suggest. Modernisation theory attempts to explain the risk factors that predispose a country to make a transition towards democracy. While Egypt certainly exhibited some of these factors, including growing education levels, an ever expanding middle class, increases in international trade, investment and tourism, and a shift in societal values and attitudes, democracy has not eventuated. The case of Egypt reveals a weakness of modernisation theory, in that it fails to account for cases of regime breakdown, and the significant societal divisions and state weaknesses which follow such episodes.

\footnotetext{
2 Steven Levitsky and Lucan A. Way, Competitive Authoritarianism: Hybrid Regimes After the Cold War (New York: Cambridge University Press, 2010). p. 354; Randall Collins, "Tipping Point Revolutions and State Breakdown Revolutions: Why Revolutions Succeed or Fail", The Sociological Eye, 2013, Available Online at: http://sociologicaleye.blogspot.co.nz/2013/06/tipping-point-revolutions-and-state.html. (Accessed: 18 September 2013)
} 
Theories related to economic inequality and crisis are also not strongly supported by the case of Egypt. Despite statements directly linking issues of inequality, corruption, inflation and poverty to the upsurge of protest, further analysis has revealed that these factors were not as pervasive in the lead up to the Egyptian Revolution as many accounts suggest. In fact, it seems that perceptions of economic grievances were more important in shaping people's response to the Mubarak regime than reality. The idea of perception can also explain the lack of utility behind arguments relating to economic crisis in the Egyptian case. Mubarak's removal coincided nicely with the fallout from the global financial crisis, which led some observers to strongly link the two. However, Egypt did not experience major economic downturn in line with the deep periods of economic crisis that have destabilised authoritarian regimes in the past. Instead, it appears that ordinary Egyptians felt a general sense of disillusionment with their economy and the opportunities it afforded them.

In Chapter Seven I discussed arguments linking religion and culture to the prospect of democracy. Such arguments are apparent throughout the literature, and are particularly pertinent when considering the case of Egypt, as Islam and democracy have been labelled as incompatible. However, there are stronger structural arguments for explaining the 'democracy deficit' in Egypt under Mubarak, as well as the wider Arab region, which are largely to do with geopolitical dynamics and the nature of the Egyptian economy. Mubarak also employed a number of tools to solidify his rule, including the use of elections to monitor individuals and formally institutionalise his dominance, and instilled fear amongst the population through violent repression, particularly at the hands of the internal security apparatus. In addition, we can observe widespread support for democracy through the Arab Barometer study and the World Values Survey. However, further analysis beyond headline indicators also reveals widespread support for factors that are not considered aspects of a liberal democracy. Yet this is not necessarily due to factors relating to religion and culture, and may be better explained by Egypt's lack of experience with democracy and the continued persistence of unrest in the years since 2011. Egypt has already experienced an attempt at an Islamist-led democracy under Morsi, and despite the fact that his presidency was cut short, the Muslim Brotherhood remains an important actor unlikely to accept continued exclusion from the political scene. Despite the fact that any Islamist-led democracy in Egypt is unlikely to reflect traditional Western conceptions of liberal democracy, the two are not necessarily irreconcilable.

\section{The Uncertainty of Egypt's Transition}

The case of Egypt is a classic example of the pitfalls many commentators encounter when considering transitions away from authoritarianism and towards democracy. Transitions away from 
authoritarianism are not the same as processes of democratisation, and they do not necessarily precede a transition to democracy. In fact, when considering history, reversions to an authoritarian or hybrid regime are not uncommon. The case of Egypt also shows that there is no such thing as 'best practice' for transitions, ${ }^{3}$ and that generalisations attempting to explain the process of transition can often be dangerous. In fact, Carothers argues that it is time to "discard the transition paradigm" ${ }^{\prime 4}$ and the assumptions associated with it, including that countries undergoing transition are on the path to democracy, and that transitions involve a linear, three-part process of democratisation. ${ }^{5}$ Bunce makes a similar point, arguing that it is difficult to apply generalisations to democratic transitions, as each case is so vastly different in terms of the nature of the prior regime, the mode of regime change itself, and the challenges facing the transition. ${ }^{6}$ Commentators on Egypt have begun to realise this, and the euphoric headlines have died down somewhat in the intervening years since the revolution. Both academic and media commentators have begun to query why the 'Arab Spring' has yielded such limited success, ${ }^{7}$ while others have declared the Egyptian transition itself a complete failure. ${ }^{8}$ Others argue that democracy appears an unlikely outcome for Egypt, and what we are instead witnessing is an authoritarian transformation, as opposed to a transition towards democracy. ${ }^{9}$ Freedom House has categorised Egypt as 'not free,' and the most recent release of the Egypt Democracy Compass reveals seven out of the eight indicators of democratic progress were rated as 'stalled' or 'backsliding,' with progress towards elections remaining the one (highly questionable) exception. ${ }^{10}$

The prospects for democracy in Egypt are looking increasingly bleak. Elections are due to be held this month, however al-Sisi is expected to win easily in the absence of any real competition, particularly since the Muslim Brotherhood has been side-lined. ${ }^{11}$ In the wake of the 2013 coup that ousted

\footnotetext{
3 Jay Ulfelder, "There are no best practices for democratic transitions", Dart-Throwing Chimp, 2013, Available Online at: http://dartthrowingchimp.wordpress.com/2013/08/23/there-are-no-best-practices-for-democratic-transitions/. (Accessed: 15 April 2014)

${ }^{4}$ Thomas Carothers, "The End of the Transition Paradigm," Journal of Democracy 13, no. 1 (2002): p. 17.

5 Ibid.

6 Valerie Bunce, "Comparative Democratization: Big and Bounded Generalizations," Comparative Political Studies 33, no. 67 (2000).

7 Jason Brownlee, Tarek Masoud, and Andrew Reynolds, "Why the Modest Harvest?," Journal of Democracy 24, no. 4 (2013).

${ }^{8}$ Nathan J. Brown, "Egypt's Failed Transition," Journal of Democracy 24, no. 4 (2013).

9 Holger Albrecht, "Authoritarian Transformation or Transition from Authoritarianim? Insights on Regime Change in Egypt," in The Arab Spring in Egypt: Revolution and Beyond, ed. Bahgat Korany and Rabab El-Mahdi (Cairo: The American University in Cairo Press, 2012), p. 251.

${ }^{10}$ Freedom House, "Death Sentences Reinforce Failure of Egypt's Transition," Freedom House, 2014, Available Online at: http://freedomhouse.org/article/death-sentences-reinforce-failure-egypt-transition\#.U3BLg4GSyvN. (Accessed: 9 May 2014)

11 Michele Dunne, "Five Questions for Sisi, Egypt's Man of Mystery," Carnegie Endowment for International Peace, 2014, Available Online at: http://carnegieendowment.org/2014/03/26/five-questions-for-sisi-egypt-s-man-of-mystery/h5ua. (Accessed: 3 April 2014)
} 
Morsi, the security situation has deteriorated significantly, with an estimated 3134 deaths over the period from July through to January $2014 .{ }^{12}$ Human rights abuses have also escalated to a point where observers are describing the current situation as the worst in modern Egyptian history. ${ }^{13}$ Thousands have been arrested over the past ten months, primarily Muslim Brotherhood members, or those affiliated with Islamist organisations. ${ }^{14}$ Egypt's economic situation remains a concern, with rates of youth unemployment continuing to cause discontent. ${ }^{15}$ The unstable security situation is having an impact on tourism and foreign investment, and the economy will suffer further if US assistance to the military is halted, which some are calling for in the wake of rampant human rights abuses. ${ }^{16}$ The post-revolution environment has also revealed deep societal divisions, particularly apparent along the Islamist divide, which are only compounding the difficulties already facing Egypt. $^{17}$

However, is it unfair to completely disregard the potential for democracy to emerge in Egypt? As Berman outlines, Egypt is experiencing problems that are "entirely normal and predictable," and it is often forgotten that many of today's stable liberal democracies did not have an easy time getting there either. ${ }^{18}$ One certainty is that the events of the 2011 revolution have irreversibly changed the nature of Egyptian society. Large swathes of the Egyptian population are not likely to accept a return to authoritarian rule in the long term, which is evidenced by the on-going unrest that continues to make international news headlines. It will be interesting to follow future developments in Egypt. Will the euphoria for democracy that was thick during the exhilarating days of 2011 count for anything, or will Egypt remain firmly on its current path back towards authoritarian rule?

\footnotetext{
12 Michele Dunne and Scott Williamson, "Egypt's Unprecedented Instability by the Numbers," Carnegie Endowment for International Peace, 2014, Available Online at: http://carnegieendowment.org/2014/03/24/egypt-s-unprecedentedinstability-by-numbers/h5j3. (Accessed: 3 April 2014)

13 Dunne, "Five Questions for Sisi, Egypt's Man of Mystery".

${ }^{14}$ Dunne and Williamson, "Egypt's Unprecedented Instability by the Numbers".

${ }^{15}$ Dunne, "Five Questions for Sisi, Egypt's Man of Mystery".

16 Ernesto Londoño, "Sen. Leahy blocks U.S. aid to Egypt to protest nation's 'appalling abuse of justice system'," The Washington Post, 2014, Available Online at: http://www.washingtonpost.com/world/national-security/sen-leahy-blocksus-aid-to-egypt-to-protest-nations-appalling-abuse-of-justice-system/2014/04/29/4d5feOfc-cfe3-11e3-937fd3026234b51c story.html?utm source=Sailthru\&utm medium=email\&utm term=\%2AMideast\%20Brief\&utm campaign= Mideast\%20brief\%204-30-14. (Accessed: 3 May 2014)

17 Brown, "Egypt's Failed Transition," p. 45.

18 Sheri Berman, "The Promise of the Arab Spring: In Political Development, No Gain Without Pain," Foreign Affairs, 2013, Available Online at: http://www.foreignaffairs.com/articles/138479/sheri-berman/the-promise-of-the-arab-spring?cid=nlcthis week on foreignaffairs co-013113-the promise of the arab spring 4-013113. (Accessed: 19 September 2013)
} 


\section{Bibliography}

Abdelaziz, Salma. "Egypt's Military Gives Morsy Ultimatum." CNN, 2013, Available Online at: http://edition.cnn.com/2013/07/01/world/meast/egypt-protests/index.html?hpt=hp t1. (Accessed: 23 September 2013)

Abdelrahman, M. "A Hierarchy of Struggles? The 'Economic' and the 'Political' in Egypt's Revolution." Review of African Political Economy 39, no. 134 (2012): 614-628

Abdelrahman, Maha M. Civil Society Exposed: The Politics of Ngos in Egypt. London: Tauris Academic Studies, 2004.

Abdulla, Rasha A. "The Revolution Will Be Tweeted: The Story of Digital Activism in Egypt." The Cairo Review of Global Affairs 3 (2011): 41-49.

Abouzeid, Rania. "Bouazizi: The Man Who Set Himself and Tunisia on Fire." Time Magazine, 2011, Availble Online at: http://content.time.com/time/magazine/article/0,9171,2044723,00.html. (Accessed: 14 May 2013)

Acemoglu, Daron, and James A. Robinson. "A Theory of Political Transitions." The American Economic Review 91, no. 4 (2001): 938-963.

Acemoglu, Daron, and James A. Robinson. Economic Origins of Dictatorship and Democracy. Cambridge: Cambridge University Press, 2006.

Al Arabiya. "Anti-Mursi 'Rebel' Campaign Receives More Than 22 Million Signatures." Al Arabiya, 2013, Available Online at: http://english.alarabiya.net/en/News/middle-east/2013/06/29/-Rebelcampaign-receives-more-than-22-million-signatures-in-anti-Mursi-petition.html. (Accessed: 2 August 2013)

Al Jazeera. "Egypt's Liberals Stage Walkout." Al Jazeera, 2012, Available Online at: http://www.aljazeera.com/news/middleeast/2012/06/201261214526684972.html. (Accessed: 3 April 2013)

Al Jazeera. "Muslim Brotherhood Members Sentenced to Death." Al Jazeera, 2014, Available Online at: http://www.aljazeera.com/news/middleeast/2014/03/muslim-brotherhood-memberssentenced-death-201432481112672803.html. (Accessed: 19 April 2014)

Al Jazeera. "Protesters across Egypt Defy Curfew." Al Jazeera, 2011, Available Online at: http://www.aljazeera.com/news/middleeast/2011/01/201112816845606511.html. (Accessed: 23 January 2014)

Al Jazeera. "Scores Killed in Clashes at Pro-Morsi Rally." Al Jazeera, 2013, Available Online at: http://www.aljazeera.com/news/middleeast/2013/07/201372774215454742.html. (Accessed: 15 September 2013)

al-Anani, Khalil, and Maszlee Malik. "Pious Way to Politics: The Rise of Political Salafism in PostMubarak Egypt." Digest of Middle East Studies 22, no. 1 (2013): 57-73. 
Albrecht, Holger. "Authoritarian Transformation or Transition from Authoritarianim? Insights on Regime Change in Egypt." In The Arab Spring in Egypt: Revolution and Beyond, edited by Bahgat Korany and Rabab El-Mahdi. 251-270. Cairo: The American University in Cairo Press, 2012.

Alissa, Sufyan. The Political Economy of Reform in Egypt: Understanding the Role of Institutions. Washington DC: The Carnegie Middle East Centre, 2007.

Amin, Galal. Egypt in the Era of Hosni Mubarak, 1981-2011. Cairo: The American University in Cairo Press, 2011.

Arjomand, Said Amir. "The Islam and Democracy Debate after 2011." Constellations 20, no. 2 (2013): 297-311.

Asad, Talal. "Fear and the Ruptured State: Reflections on Egypt after Mubarak." Social Research 79, no. 2 (2012): 271-298.

Aziz, Muhammad Abdul, and Youssef Hussein. "The President, the Son, and the Military: The Question of Succession in Egypt." The Arab Studies Journal 9/10, no. 1/2 (2001/2002): 73-88.

Banai, Hussein. "Democratic Solidarity: Rethinking Democracy Promotion in the New Middle East." Security Dialogue 55, no. 5-6 (2013): 411-429.

Barany, Zoltan. "Armies and Revolutions." Journal of Democracy 24, no. 2 (2013): 62-76.

Barany, Zoltan. "Comparing the Arab Revolts: The Role of the Military." Journal of Democracy 22, no. 4 (2011): 24-35.

Bates, Theunis. "Protestors Left in the Dark as Egypt Blocks Internet." AolNews, 2011, Available Online at: http://www.aolnews.com/2011/01/28/protesters-left-in-the-dark-as-egypt-blocksinternet-cell-phone/. (Accessed: 11 June 2013)

Bayat, Asef. "The Arab Spring and Its Surprises." Development and Change 44, no. 3 (2013): 587-601.

BBC. "Egypt Severs Internet Connection Amid Growing Unrest." BBC, 2011, Available Online at: http://www.bbc.co.uk/news/technology-12306041. (Accessed: 18 September 2013)

BBC. "Egypt: Brotherhood's Badie among Mass Death Sentences." BBC, 2014, Available Online at: http://www.bbc.com/news/world-middle-east27186339?utm source=Sailthru\&utm medium=email\&utm term=\%2AMideast\%20Brief\&utm cam paign=Mideast\%20brief\%204-28-14. (Accessed: 1 May 2014)

BBC. "Egyptian Military Dissolves Parliament." BBC, 2011, Available Online at: http://www.bbc.co.uk/news/world-middle-east-12443678. (Accessed: 14 May 2013)

BBC. "Egyptian Voters Back New Constitution in Referendum." BBC, 2012, Available Online at: http://www.bbc.com/news/world-middle-east-20842487. (Accessed: 24 March 2013)

BBC. "Egypt's President Mursi Assumes Sweeping Powers." BBC, 2012, Available Online at: http://www.bbc.com/news/world-middle-east-20451208. (Accessed: 11 March 2013) 
Beinin, Joel. "Egyptian Workers and January 25th: A Social Movement in Historical Context." Social Research 79, no. 2 (2012): 323-348.

Beissinger, Mark R. "Structure and Example in Modular Political Phenomena: The Diffusion of Bulldozer/Rose/Orange/Tulip Revolutions." Perspectives on Politics 5, no. 02 (2007): 259-276.

Bellin, Eva. "Reconsidering the Robustness of Authoritarianism in the Middle East: Lessons from the Arab Spring." Comparative Politics 44, no. 2 (2012): 127-149.

Berman, Sheri. "The Promise of the Arab Spring: In Political Development, No Gain without Pain." Foreign Affairs, 2013, Available Online at: http://www.foreignaffairs.com/articles/138479/sheriberman/the-promise-of-the-arab-spring?cid=nlc-this week on foreignaffairs co-013113the promise of the arab spring 4-013113. (Accessed: 19 September 2013)

Blaydes, L., and J. Lo. "One Man, One Vote, One Time? A Model of Democratization in the Middle East." Journal of Theoretical Politics 24, no. 1 (2011): 110-146.

Blaydes, Lisa. Elections and Distributive Politics in Mubarak's Egypt. New York: Cambridge University Press, 2011.

Boix, Carles, and Susan C. Stokes. "Endogenous Democratization." World Politics 55, no. 4 (2003): 517-549.

Boix, Carles. "Development and Democratization." IBEI Working Papers 26 (2009).

Boix, Carles. Democracy and Redistribution. Cambridge: Cambridge University Press, 2003.

Bowen, Jeremy. "Egypt Unrest: Obama Increases Pressure on Mubarak." BBC, 2011, Available Online at: http://www.bbc.co.uk/news/world-us-canada-12371479. (Accessed: 8 August 2013)

Brown, Nathan J. "Egypt's Failed Transition." Journal of Democracy 24, no. 4 (2013): 45-58.

Brown, Nathan J., and Michele Dunne. "Egypt's Judges Join In." Carnegie Endowment for International Peace, 2014, Available Online at: http://carnegieendowment.org/2014/04/02/egypt-sjudges-join-in/h6tf. (Accessed: 24 April 2014)

Brownlee, Jason, Tarek Masoud, and Andrew Reynolds. "Why the Modest Harvest?". Journal of Democracy 24, no. 4 (2013): 29-44.

Brynen, Rex, Pete W. Moore, Bassel F. Salloukh, and Marie-Joëlle Zahar. Beyond the Arab Spring: Authoritarianism and Democratisation in the Arab World. Boulder, Colorado: Lynne Rienner Publishers, Inc., 2012.

Bunce, Valerie. "Comparative Democratization: Big and Bounded Generalizations." Comparative Political Studies 33, no. 6-7 (2000): 703-734.

Burkhart, Ross E., and Michael S. Lewis-Beck. "Comparative Democracy: The Economic Development Thesis." The American Political Science Review 88, no. 4 (1994): 903-910. 
Carapico, Sheila. "Egypt's Civic Revolution Turns 'Democracy Promotion' on Its Head." In The Arab Spring in Egypt: Revolution and Beyond, edited by Bahgat Korany and Rabab El-Mahdi. 199-222. Cairo: The American University in Cairo Press, 2012.

Carapico, Sheila. "Foreign Aid for Promoting Democracy in the Arab World." Middle East Journal 56, no. 3 (2002): 379-395.

Caromba, Laurence, and Hussein Solomon. "Understanding Egypt's Muslim Brotherhood." African Security Review 17, no. 3 (2008): 117-124.

Carothers, Thomas. "The End of the Transition Paradigm." Journal of Democracy 13, no. 1 (2002): 521.

Charbel, Jano. "Protest Stand in Solidarity with Tunisian Revolution." SHE2/2, 2011, Available Online at: https://www.blogger.com/profile/12892813403512393124. Accessed: 17 June 2013

Chehabi, H. E, and Juan J. Linz. "A Theory of Sultanism I: A Type of Nondemocratic Rule." In Sultanistic Regimes, edited by H. E Chehabi and Juan J. Linz. pp. 3-25. Baltimore, MA: The John Hopkins University Press, 1998.

CIA. "The World Factbook: Egypt." CIA, 2014, Available Online at: https://www.cia.gov/library/publications/the-world-factbook/geos/eg.html. (Accessed: 15 March 2014)

Ciezadlo, Annia. "Let Them Eat Bread: How Food Subsidies Prevent (and Provoke) Revolutions in the Middle East." In The New Arab Revolt, edited by The Council on Foreign Relations. 229-235. New York: The Council on Foreign Relations, 2011.

Cohen, Roger. "Facebook and Arab Dignity." New York Times, 2011, Available Online at: http://www.nytimes.com/2011/01/25/opinion/25iht-edcohen25.html. (Accessed: 11 November 2013)

Cole, Juan. "Egypt's New Left Versus the Military Junta." Social Research 79, no. 2 (2012): 487-510.

Collier, Ruth Berins. Paths toward Democracy: The Working Class and Elites in Western Europe and South America. Cambridge: Cambridge University Press, 1999.

Collins, Randall. "Tipping Point Revolutions and State Breakdown Revolutions: Why Revolutions Succeed or Fail." The Sociological Eye, 2013, Available Online at: http://sociologicaleye.blogspot.co.nz/2013/06/tipping-point-revolutions-and-state.html. (Accessed: 18 September 2013)

Dahl, Robert A. Polyarchy: Participation and Opposition. New Haven: Yale Universty Press, 1971.

Daily News Egypt. "Egyptian Activists Call for Protest in Solidarity with Tunisians." Daily News Egypt, 2013, Available Online at: http://www.dailynewsegypt.com/2010/12/30/egyptian-activists-call-tojoin-protests-over-tunisia-injustices/. (Accessed: 17 June 2013)

Day, Elizabeth. "The Slap That Sparked a Revolution." The Guardian, 2011, Available Online at: http://www.theguardian.com/world/2011/may/15/arab-spring-tunisia-the-slap. (Accessed: 11 February 2013) 
Deutsche Welle. "Egypt Jails More Than 100 Muslim Brotherhood Supporters." Deutsche Welle, 2014, Available Online at: http://www.dw.de/egypt-jails-more-than-100-muslim-brotherhoodsupporters/a-17573768. (Accessed: 19 April 2014)

Di Palma, Giuseppe. To Craft Democracies: An Essay on Democratic Transitions. Oxford, England: University of California Press, 1990.

Diamond, Larry. "A Fourth Wave or False Start?" Foreign Affairs, 2011, Available Online at: http://www.foreignaffairs.com/print/67794. (Accessed: 13 June 2013)

Diamond, Larry. "Democracy's Third Wave Today." Current History 110, no. 739 (2011): 299-307.

Diamond, Larry. "Why Are There No Arab Democracies?". Journal of Democracy 21, no. 1 (2010): $93-$ 112.

Diamond, Larry. Developing Democracy: Toward Consolidation. Baltimore, Maryland: The John Hopkins University Press, 1999.

Droz-Vincent, Philippe. "Prospects for "Democratic Control of the Armed Forces"?: Comparative Insights and Lessons for the Arab World in Transition." Armed Forces \& Society 00, no. 0 (2013): 1-28.

Dunne, Michele, and Scott Williamson. "Egypt's Unprecedented Instability by the Numbers." Carnegie Endowment for International Peace, 2014, Available Online at: http://carnegieendowment.org/2014/03/24/egypt-s-unprecedented-instability-by-numbers/h5j3. (Accessed: 3 April 2014)

Dunne, Michele. "Five Questions for Sisi, Egypt's Man of Mystery." Carnegie Endowment for International Peace, 2014, Available Online at: http://carnegieendowment.org/2014/03/26/fivequestions-for-sisi-egypt-s-man-of-mystery/h5ua. (Accessed: 3 April 2014)

Dworkin, Anthony, Daniel Korski, and Nic Whitney. Egypt's Hybrid Revolution: A Bolder EU Approach. London: European Council on Foreign Relations, 2011.

El Molla, Nesreen Khaled. The EU's Role in Political Reform and Democracy Building in the Southern Mediterranean Region: An Egyptian Perspective. Stockholm, Sweden: International Institute for Democracy and Electoral Assistance, 2009.

ElBaradei, Mohamed. "Twitter Post." Twitter, 2012, Available Online at: https://twitter.com/ElBaradei/status/271656968341581824. (Accessed: 17 March 2013)

El-Din, Gamal Essam. "Mubarak's Most Controversial Speech." Al-Ahram Weekly, 2006, Available Online at: http://weekly.ahram.org.eg/2006/821/eg1.htm. (Accessed: 23 April 2014)

el-Hamalawy, Hossam. "Egypt's Revolution Has Been 10 Years in the Making." The Guardian, 2011, Available Online at: http://www.theguardian.com/commentisfree/2011/mar/02/egypt-revolutionmubarak-wall-of-fear. (Accessed: 26 September 2013)

El-Mahdi, Rabab. "Enough! Egypt's Quest for Democracy." Comparative Political Studies 42, no. 8 (2009): 1011-1039. 
Epstein, David L., Robert Bates, Jack Goldstone, Ida Kristensen, and Sharyn O'Halloran. "Democratic Transitions." American Journal of Political Science 50, no. 3 (2006): 551-569.

Fahmy, Hazem. "An Initial Perspective on "the Winter of Discontent": The Root Causes of the Egyptian Revolution." Social Research 79, no. 2 (2012): 349-376.

Fahmy, Ninette S. The Politics of Egypt: State-Society Relationship. Oxford, UK: Routledge, 2002.

Finley, J.C. "Egypt Bans Muslim Brotherhood Candidates from Elections." United Press International, 2014, Available Online at: http://www.upi.com/Top News/World-News/2014/04/16/Egypt-bansMuslim-Brotherhood-candidates-from-elections/6061397657589/. (Accessed: 19 April 2014)

Fish, M. Steven. "Islam and Authoritarianism." World Politics 55, no. 01 (2011): 4-37.

Food and Agriculture Organisation. "World Food Prices Reach New Historic Peak." Food and Agriculture Organisation, 2011, Available Online at: http://www.fao.org/news/story/en/item/50519/icode/. (Accessed: 17 July 2013)

Food and Agriculture Organisation. "World Food Situation." Food and Agriculture Organisation, 2013, Available Online at: http://www.fao.org/worldfoodsituation/foodpricesindex/en/. (Accessed: 17 July 2013)

Freedom House. "Death Sentences Reinforce Failure of Egypt's Transition." Freedom House, 2014, Available Online at: http://freedomhouse.org/article/death-sentences-reinforce-failure-egypttransition\#.U3BLg4GSyvN. (Accessed: 9 May 2014)

Frisch, Hillel. "The Egyptian Army and Egypt's 'Spring'." Journal of Strategic Studies 36, no. 2 (2013): 180-204.

Fukuyama, Francis. "The Middle-Class Revolution." The Wall Street Journal, 2013, Available Online at: http://online.wsj.com/news/articles/SB10001424127887323873904578571472700348086.

(Accessed: 11 February 2014)

Geddes, Barbara. "Changes in the Causes of Democratization through Time." In The Sage Handbook of Comparative Politics, edited by Todd Landman and Neil Robinson. 278-295: SAGE Publications, 2009.

Geddes, Barbara. "What Do We Know About Democratisation after Twenty Years?". Annual Review of Political Science 2 (1999): 115-144.

Geddes, Barbara. "Why Parties and Elections in Authoritarian Regimes?" In Annual Meeting of the American Political Science Association. Washington DC, 2005.

Gelvin, J. L. The Arab Uprisings: What Everyone Needs to Know. New York: Oxford University Press, 2012.

Gerges, Fawaz. "Egypt Coup: The Military Has Not Just Ousted Morsi. It Has Ousted Democracy." The Guardian, 2013, Available Online at: http://www.theguardian.com/commentisfree/2013/jul/04/egypt-coup-military-morsi-democracy. (Accessed: 15 July 2013) 
Gleditsch, Kristian Skrede, and Michael D. Ward. "Diffusion and the International Context of Democratisation." International Organization 60, no. 4 (2006): 911-933.

Goldberg, Ellis. "Mubarakism without Mubarak: Why Egypt's Military Will Not Embrace Democracy." In The New Arab Revolt, edited by The Council on Foreign Relations. 110-114. New York: The Council on Foreign Relations, 2011.

Gustin, Sam. "Social Media Sparked, Accelerated Egypt's Revolutionary Fire." Wired.com, 2011, Available Online at: http://www.wired.com/business/2011/02/egypts-revolutionary-fire/. (Accessed: 3 November 2013)

Hadenius, Axel, and Jan Teorell. "Pathways from Authoritarianism." Journal of Democracy 18, no. 1 (2007): 143-157.

Haggard, Stephan, and Robert R. Kaufman. The Political Economy of Democratic Transitions. Princeton, N.J: Princeton University Press, 1995.

Hale, Henry E. "Regime Change Cascades: What We Have Learned from the 1848 Revolutions to the 2011 Arab Uprisings." Annual Review of Political Science 16, no. 1 (2013): 331-353.

Hamdy, Sherine F. "Strength and Vulnerability after Egypt's Arab Spring Uprisings." American Ethnologist 39, no. 1 (2012): 43-48.

Harb, Imad. "The Egyptian Military in Politics: Disengagement or Accommodation?". Middle East Journal 57, no. 2 (2003): 269-290.

Hass, Richard N. "Reflections on the Revolution in Egypt." In The New Arab Revolt, edited by The Council on Foreign Relations. 115-118. New York: The Council on Foreign Relations, 2011.

Hazran, Yusri. "The Arab Revolutions: A Preliminary Reading." Middle East Policy 19, no. 3 (2012): 116-123.

Hellyer, H. A. "The Chance for Change in the Arab World: Egypt's Uprising." International Affairs 87, no. 6 (2011): 1313-1322.

Hess, Steve. "From the Arab Spring to the Chinese Winter: The Institutional Sources of Authoritarian Vulnerability and Resilience in Egypt, Tunisia, and China." International Political Science Review 34, no. 3 (2013): 254-272.

Hibbard, Scott, and Azza Salama Layton. "The Origins and Future of Egypt's Revolt." Journal of Islamic Law and Culture 12, no. 3 (2010): 197-214.

Hlasny, Vladimir, and Paolo Verme. "Top Incomes and the Measurement of Inequality in Egypt." The World Bank, 2013.

Hollis, Rosemary. "No Friend of Democratization: Europe's Role in the Genesis of the 'Arab Spring'." International Affairs 88, no. 1 (2012): 81-94.

Holmes, Amy Austin. "There Are Weeks When Decades Happen: Structure and Strategy in the Egyptian Revolution." Mobilization 17, no. 4 (2012): 319-410. 
Houle, Christian. "Inequality and Democracy: Why Inequality Harms Consolidation but Does Not Affect Democratization." World Politics 61, no. 04 (2009): 589-622.

Huntington, Samuel P. "Democracy's Third Wave." Journal of Democracy 2, no. 2 (1991): 12-34.

Huntington, Samuel P. The Third Wave: Democratization in the Late Twentieth Century. Vol. 4, Norman: University of Oklahoma Press, 1993.

Hussain, Muzammil M., and Philip N. Howard. "Democracy's Fourth Wave? Information Technologies and the Fuzzy Causes of the Arab Spring." In International Studies Association. San Diego, 2012.

Hussein, Abdel-Rahman. "Egypt Referendum: Opposition Calls for Fraud Inquiry." The Guardian, 2012, Available Online at: http://www.theguardian.com/world/2012/dec/23/egypt-referendumopposition-fraud-inquiry. (Accessed: 3 April 2013)

Inglehart, Ronald. "How Solid Is Mass Support for Democracy - and How Can We Measure It?". PS: Political Science and Politics 36 (2003): 51-57.

Jamal, Amaney A. "Reassessing Support for Islam and Democracy in the Arab World? ." World Affairs 169, no. 2 (2006): 51-63.

Jamal, Amaney, and Mark Tessler. "The Democracy Barometers: Attitudes in the Arab World." Journal of Democracy 19, no. 1 (2008): 97-110.

Jenkins, J. Craig, Katherine Meyer, Matthew Costello, and Hassan Aly. "International Rentierism in the Middle East and North Africa, 1971-2008." International Area Studies Review 14, no. 3 (2011): 330.

Joffé, George. "The Arab Spring in North Africa: Origins and Prospects." The Journal of North African Studies 16, no. 4 (2011): 507-532.

Kandil, Hazem. "Back on Horse? The Military between Two Revolution." In The Arab Spring in Egypt: Revolution and Beyond, edited by Bahgat Korany and Rabab El-Mahdi. 175-197. Cairo: The American University in Cairo Press, 2012.

Kandil, Hazem. "Why Did the Egyptian Middle Class March to Tahrir Square." Mediterranean Politics 17, no. 2 (2012): 197-215.

Kandil, Hazem. Soliders, Spies, and Statesmen: Egypt's Road to Revolt. London: Verso, 2012.

Karon, Tony. "Mubarak Says He Is Handing Off Powers but Hanging On." Time Magazine, 2011, Available Online at: http://content.time.com/time/world/article/0,8599,2048250,00.html.

(Accessed: 2 August 2013)

Kassem, Maye. Egyptian Politics: The Dynamics of Authoritarian Rule. Boulder, Colorado: Lynne Reinner Publishers, Inc., 2004.

Kedourie, Elie. Democracy and Arab Political Culture. London: Frank Cass Publishers, 1994.

Kellog Institute for International Studies. The Tipping Point: Transitions to Democracy in Latin America and the Middle East. Notre Dame, Indiana: University of Notre Dame, 2012. 
Kendzior, Sarah. "The Men Who Set Themselves on Fire." Al Jazeera America, 2013, Available Online at: http://www.aljazeera.com/indepth/opinion/2013/10/men-who-set-themselves-fire20131075515834438.html. (Accessed: 3 November 2013)

Kennedy, Ryan. "The Contradiction of Modernization: A Conditional Model of Endogenous Democratization." The Journal of Politics 72, no. 03 (2010): 785-798.

Khamis, Sahar, and Katherine Vaughn. "Cyberactivism in the Egyptian Revolution: How Civic Engagement and Citizen Journalism Tilted the Balance." Arab Media and Society 13 (2011): 1-37.

Kingsley, Patrick. "Egypt Army Chief Abdel Fatah Al-Sisi Indicates He Will Run for Presidency." The Guardian, 2014, Available Online at: http://www.theguardian.com/world/2014/mar/04/egypt-armychief-abdel-fatah-al-sisi-indicates-run-presidency. (Accessed: 22 March 2014)

Kingsley, Patrick. "Egypt: 49 People Killed in Protests on Third Anniversary of Uprising." The Guardian, 2014, Available Online at: http://www.theguardian.com/world/2014/jan/26/egypt-49killed-protests-third-anniversary-uprising. (Accessed: 11 March 2014)

Kitchen, Nicholas. After the Arab Spring: Power Shift in the Middle East?: The Contradictions of Hegemony: The United States and the Arab Spring. London: London School of Economics and Political Science, 2012.

Knickmeyer, Ellen. "The Arab World's Youth Army." Foreign Policy, 2011, Available Online at: http://www.foreignpolicy.com/articles/2011/01/27/the arab world s youth army?page=0,0. (Accessed: 17 July 2013)

Kopstein, Jeffrey. "The Transatlantic Divide over Democracy Promotion." The Washington Quarterly 29, no. 2 (2006): 85-98.

Korany, Bahgat, and Rabab El-Mahdi, eds. The Arab Spring in Egypt: Revolution and Beyond. Cairo: The American University in Cairo Press, 2012.

Langohr, Vickie. "Too Much Civil Society, Too Little Politics: Egypt and Liberalizing Arab Regimes." Comparative Politics 36, no. 2 (2004): 181-204.

Lankford, Adam. "Suicide for a Cause: What's Behind the Middle East's New Trend of SelfImmolation?" Foregin Policy, 2011, Available Online at: http://www.foreignpolicy.com/articles/2011/01/19/suicide for a cause. (Accessed: 11 March 2013)

Lesch, Ann M. "Concentrated Power Breeds Corruption, Repression and Resistance." In The Arab Spring in Egypt: Revolution and Beyond, edited by Bahgat Korany and Rabab El-Mahdi. 17-42. Cairo: The American University in Cairo Press, 2012.

Levine, Daniel H. "Paradigm Lost: Dependence to Democracy." World Politics 40, no. 3 (1988): $377-$ 394.

Levitsky, Steven, and Lucan A. Way. Competitive Authoritarianism: Hybrid Regimes after the Cold War. New York: Cambridge University Press, 2010. 
Levitsky, Steven, and Lucan Way. "International Linkage and Democratization." Journal of Democracy 16, no. 3 (2005): 20-34.

Lewis, Bernard. Islam and the West. Oxford: Oxford University Press, 1993.

Lim, Merlyna. "Clicks, Cabs, and Coffee Houses: Social Media and Oppositional Movements in Egypt, 2004-2011." Journal of Communication 62 (2012): 231-248.

Lindsey, Ursula. "The Cult of Sisi." The New York Times, 2013, Available Online at: http://latitude.blogs.nytimes.com/2013/09/12/the-cult-ofsisi/? php=true\& type=blogs\& $r=0$ \&version=meter+at+5\&region=FixedCenter\&pgtype=Blogs\&prior ity=true\&module=RegiWall-Regi\&action=click. (Accessed: 24 September 2013)

Linz, Juan J., and Alfred Stepan. Problems of Democratic Transition and Consolidation: Southern Europe, South America, and Post-Communist Europe. Baltimore, MA: The John Hopkins University Press, 1996.

Lipset, Seymour Martin. "Some Social Requisites of Democracy: Economic Development and Political Legitimacy." The American Political Science Review 53, no. 1 (1959): 69-105.

Lipset, Seymour Martin. "The Social Requisites of Democracy Revisited." American Sociological Review 59 (1994): 1-22.

Londoño, Ernesto. "Sen. Leahy Blocks U.S. Aid to Egypt to Protest Nation's 'Appalling Abuse of Justice System'." The Washington Post, 2014, Available Online at:

http://www.washingtonpost.com/world/national-security/sen-leahy-blocks-us-aid-to-egypt-toprotest-nations-appalling-abuse-of-justice-system/2014/04/29/4d5feOfc-cfe3-11e3-937fd3026234b51c story.html?utm source=Sailthru\&utm medium=email\&utm term=\%2AMideast\%20 Brief\&utm campaign=Mideast\%20brief\%204-30-14. (Accessed: 3 May 2014)

Lutterbeck, Derek. "Arab Uprisings, Armed Forces, and Civil-Military Relations." Armed Forces \& Society 39, no. 28 (2012): 28-52.

Lynch, Marc. "After Egypt: The Limits and Promise of Online Challenges to the Authoritarian Arab State." Perspectives on Politics 9, no. 02 (2011): 301-310.

MacEwan, Arthur. "Review "Transitions from Authoritarian Rule"." Latin American Perspectives 15, no. 3 (1988): 115-130.

Magaloni, Beatriz. "Credible Power-Sharing and the Longevity of Authoritarian Rule." Comparative Political Studies 51, no. 4/5 (2008): 715-741.

Markakis, Dionysius. US Democracy Promotion in the Middle East: The Pursuit of Hegemony?, The London School of Economics and Political Science, 2012.

McFarquhar, Neil. "Protesters Scold Egypt's Military Council." The New York Times, 2011, Available Online at: http://www.nytimes.com/2011/04/02/world/middleeast/02egypt.html? $r=3 \&$.

(Accessed: 14 May 2013) 
McGreal, Chris. "Egypt: Bread Shortages, Hunger and Unrest." The Guardian, 2008, Available Online at: http://www.guardian.co.uk/environment/2008/may/27/food.egypt. (Accessed: 11 February 2013)

McLaughlin, Andrew. "Egypt's Big Internet Disconnect." The Guardian, 2011, Available Online at: http://www.theguardian.com/commentisfree/2011/jan/31/egypt-internet-uncensored-cutoffdisconnect. (Accessed: 14 July 2013)

Miller, Laurel E., Jeffrey Martini, F. Stephen Larrabee, Angel Rabasa, Stephanie Pezard, Julie E. Taylor, and Tewodaj Mengistu. Democratization in the Arab World: Prospects and Lessons from around the Globe. Santa Monica, CA: RAND Corporation, 2012.

Mohamadieh, Kinda. "Egypt and the IMF: Conditions as Usual." Middle East Institute, 2013, Available Online at: http://www.mei.edu/content/egypt-imf-conditions-usual. (Accessed: 1 July 2013)

Møller, Jørgen, and Svend-Erik Skaaning. "Regime Types and Democratic Sequencing." Journal of Democracy 24, no. 1 (2013): 142-155.

Nassef, Al-Sharif. "Revolution Square One: Egypt Three Years On." Daily News Egypt, 2014, Available Online at: http://www.dailynewsegypt.com/2014/02/15/revolution-square-one-egypt-three-years/. (Accessed: 19 April 2014)

National Endowment for Democracy. "Remarks by President George W. Bush at the 20th Anniversary of the National Endowment for Democracy." National Endowment for Democracy, 2003, Available Online at: http://www.ned.org/george-w-bush/remarks-by-president-george-w-bush-atthe-20th-anniversary. (Accessed: 23 September 2013)

Nepstad, Sharon Erickson. "Mutiny and Nonviolence in the Arab Spring: Exploring Military Defections and Loyalty in Egypt, Bahrain, and Syria." Journal of Peace Research 50, no. 4 (2013): 337-349.

Nwosu, Bernard Ugochukwu. "Tracks of the Third Wave: Democracy Theory, Democratisation and the Dilemma of Political Succession in Africa." Review of African Political Economy 39, no. 131 (2012): 11-25.

O'Donnell, Guillermo, and Philippe C. Schmitter. Transitions from Authoritarian Rule: Tentative Conclusions About Uncertain Democracies. Baltimore, Maryland: The John Hopkins University Press, 1986.

Ottaway, Marina. Democracy Challenged: The Rise of Semi-Authoritarianism. Washington DC: Carnegie Endowment for International Peace, 2003.

Oxfam International. "Egypt." Oxfam International, 2014, Available Online at: http://www.oxfam.org/en/egypt. (Accessed: 3 December 2013)

Pearlman, Wendy. "Emotions and the Microfoundations of the Arab Uprisings." Perspectives on Politics 11, no. 2 (2013): 387-409.

Pfeifer, Karen. "Economic Reform and Privatisation in Egypt." In The Journey to Tahrir: Revolution, Protest, and Social Change in Egypt, edited by Jeannie Sowers and Chris Toensing. 203-223. London: Verso, 2012. 
Pioppi, Daniela, Maria Cristina Paciello, Issandr El Amrani, and Philippe Droz-Vincent. "Transition to What: Egypt's Uncertain Departure from Neo-Authoritarianism." In Mediterranean Paper Series 2011. Washington DC: The German Marshall Fund of the United States, 2011.

Plattner, Marc F. "The Global Context." Journal of Democracy 22, no. 4 (2011): 5-12.

Plumer, Brad. "The Economic Roots of Egypt's Crisis." The Washington Post, 2013, Available Online at: http://www.washingtonpost.com/blogs/wonkblog/wp/2013/07/03/the-economic-roots-ofegypts-crisis/. (Accessed: 23 November 2013)

Przeworski, Adam, and Fernando Limongi. "Modernization: Theories and Facts." World Politics 49, no. 2 (1997): 155-183.

Przeworski, Adam, Michael Alvarez, José Antonio Cheibub, and Fernando Limongi. "What Makes Democracies Endure?". Journal of Democracy 7, no. 1 (1996): 39-55.

Przeworski, Adam, Michael E. Alvarez, José Antonio Cheibub, and Fernando Limongi. Democracy and Development: Political Institutions and Well-Being in the World, 1950 - 1990. Cambridge: Cambridge University Press, 2000.

Przeworski, Adam. Democracy and the Market: Political and Economic Reforms in Eastern Europe and Latin America. New York: Cambridge University Press, 1991.

Puddington, Arch. "The Year of the Arab Uprisings." Journal of Democracy 23, no. 2 (2012): 74-88.

Ramadan, Tariq. Islam and the Arab Awakening. New York: Oxford University Press, 2012.

Reza, Sadiq. "Endless Emergency: The Case of Egypt." New Criminal Law Review 10, no. 4 (2007): 532-553.

Richtel, Matt. "Egypt Cuts Off Most Internet and Cell Service." The New York Times, 2011, Available Online at: http://www.nytimes.com/2011/01/29/technology/internet/29cutoff.html. (Accessed: 18 September 2013)

Robinson, Glenn E. "Can Islamists Be Democrats? The Case of Jordan." Middle East Journal 51, no. 3 (1997): 373-387.

Rodenbeck, Mark. Holding Its Breath: A Special Report on Egypt. London: The Economist, 2010.

Rosenberg, Tina. "Revolution U." Foreign Policy, 2011, Available Online at:

http://www.foreignpolicy.com/articles/2011/02/16/revolution u?page=full. (Accessed: 14

November 2013)

Ross, Michael L. "Does Oil Hinder Democracy?". World Politics 53, no. 3 (2001): 325-361.

Ross, Michael L. "Will Oil Drown the Arab Spring? Democracy and the Resource Curse." Foreign Affairs 90, no. 5 (2011): 2-7.

Roy, Oliver. "The Transformation of the Arab World." Journal of Democracy 23, no. 3 (2012): 5-18.

Roy, Oliver. "There Will Be No Islamist Revolution." Journal of Democracy 24, no. 1 (2013): 14-19. 
Said, Edward W. Orientalism. London: Routledge and Kegan Paul Ltd., 1978.

Saideman, Stephen M. "When Conflict Spreads: Arab Spring and the Limits of Diffusion." International Interactions 38, no. 5 (2012): 713-722.

Sarihan, Ali. "Is the Arab Spring in the Third Wave of Democratisation? The Case of Syria and Egypt." Turkish Journal of Politics 3, no. 1 (2012): 67-85.

Sayigh, Yezid. "Reconstructing the Police State in Egypt." Carnegie Endowment for International Peace, 2013, Available Online at: http://carnegie-mec.org/2013/08/22/reconstructing-police-statein-egypt/gja6. (Accessed: 13 September 2013)

Schedler, Andreas, ed. Electoral Authoritarianism: The Dynamics of Unfree Competition. Boulder, Colorado: Lynne Rienner Publishers, Inc., 2006.

Schedler, Andreas. "Authoritarianism's Last Line of Defense." Journal of Democracy 21, no. 1 (2010): 69-80.

Schmitter, Philippe C. "Twenty-Five Years, Fifteen Findings." Journal of Democracy 21, no. 1 (2010): $17-28$.

Schumpeter, Joseph A. Capitalism, Socialism and Democracy. Sixth ed. London: Unwin Paperbacks, 1987.

Sharp, Jeremy M. "Egypt: Background and US Relations." Congressional Research Service, 2013.

Shediac, Richard, Samer Bohsali, and Hatem Samman. The Bedrock of Society: Understanding and Growing the MENA Region's Middle Class. Dubai, UAE: Booz and Company Inc., 2012.

Shehata, Dina. "The Fall of the Pharaoh." Foreign Affairs 90, no. 3 (2011): 26-32.

Snider, Erin A., and David M. Faris. "The Arab Spring: US Democracy Promotion in Egypt." Middle East Policy 18, no. 3 (2011): 49-62.

Soueif, Ahdaf. "Image of Unknown Woman Beaten by Egypt's Military Echoes around World." The Guardian, 2011, Available Online at:

http://www.theguardian.com/commentisfree/2011/dec/18/egypt-military-beating-femaleprotester-tahrir-square. (Accessed: 22 June 2013)

Sowers, Jeannie, and Chris Toensing, eds. The Journey to Tahrir: Revolution, Protest, and Social Change in Egypt. London and New York: Verso, 2012.

Stein, Ewan. "Revolution or Coup? Egypt's Fraught Transition." Survival 54, no. 4 (2012): 45-66.

Stepan, Alfred. "Tunisia's Transition and the Twin Tolerations." Journal of Democracy 23, no. 2 (2012): 89-103.

Tawfeed, Mohammed, and Ralph Ellis. "2 Muslim Brotherhood Members Killed as Unrest Sweeps Egypt." CNN, 2014, Available Online at: http://edition.cnn.com/2014/04/11/world/africa/violencein-egypt/. (Accessed: 19 April 2014) 
Tessler, M. "Do Islamic Orientations Influence Attitudes toward Democracy in the Arab World? Evidence from Egypt, Jordan, Morocco, and Algeria." International Journal of Comparative Sociology 43, no. 3-5 (2002): 229-249.

Tessler, Mark, Amaney Jamal, and Michael Robbins. "New Findings on Arabs and Democracy." Journal of Democracy 23, no. 4 (2012): 89-103.

Teti, Andrea, and Gennaro Gervasio. "After Mubarak, before Transition: The Challenges for Egypt's Democratic Opposition." Interface 4, no. 1 (2012): 102-112.

The Carnegie Endowment for International Peace. "The SCAF: An Overview of Its Actions." The Carnegie Endowment for International Peace, 2012, Available Online at: http://egyptelections.carnegieendowment.org/2012/01/05/the-scaf-an-overview-of-its-actions. (Accessed: 14 April 2013)

The Carnegie Endowment for International Peace. "The Constitutional Declaration." The Carnegie Endowment for International Peace, 2012, Available Online at: http://egyptelections.carnegieendowment.org/2012/06/19/the-constitutional-declaration-withjune-17-2012-annex-added. (Accessed: 5 March 2013)

The Daily Mail. "Images of Solidarity as Christians Join Hands to Protect Muslims as They Pray During Cairo Protests." The Daily Mail, 2011, Available Online at: http://www.dailymail.co.uk/news/article1353330/Egypt-protests-Christians-join-hands-protect-Muslims-pray-Cairo-protests.html. (Accessed: 16 August 2013)

The Economist. "The Scent of Jasmine Spreads." The Economist, 2011, Available Online at: http://www.economist.com/node/18010573. (Accessed: 11 March 2013)

The Guardian. "Tahrir Square Cleanup." The Guardian, 2011, Available Online at: http://www.theguardian.com/world/gallery/2011/feb/13/tahrir-square-cleanup-egyptpictures\#/?picture=371699176\&index=2. (Accessed: 11 August 2013)

The Westminster Foundation for Democracy. Annual Report and Accounts 2011/12. London: The Westminster Foundation for Democracy, 2012.

Tignor, Robert L. Egypt: A Short History. Princeton, NJ: Princeton University Press, 2010.

Time Magazine. "Person of the Year 2011: The Protestor." Time Magazine, 2011, Available Online at: http://content.time.com/time/person-of-the-year/2011/. (Accessed: 11 February 2013)

Transparency International. "Corruption Perceptions Index 2010." Transparency International, 2010, Available Online at: http://www.transparency.org/cpi2010/results. (Accessed: 16 July 2013)

Tudoroiu, Theodor. "Assessing Middle Eastern Trajectories: Egypt after Mubarak." Contemporary Politics 17, no. 4 (2011): 373-391.

Ulfelder, Jay. "There Are No "Best Practices" for Democratic Transitions." Dart-Throwing Chimp, 2013, Available Online at: http://dartthrowingchimp.wordpress.com/2013/08/23/there-are-no-bestpractices-for-democratic-transitions/. (Accessed: 15 April 2014) 
UNESCO Institute for Statistics. "UIS Statistics in Brief: Education Profile - Egypt." United Nations Educational, Scientific and Cultural Organisation, 2012, Available Online at: http://stats.uis.unesco.org/unesco/TableViewer/document.aspx?Reportld=121\&IF Language=en\&B $\underline{R}$ Country=2200. (Accessed: 22 November 2013)

United Nations Development Programme and the Institute of National Planning Egypt. "Egypt Human Development Report 2010." United Nations Development Programme, 2010.

United Nations World Tourism Organisation. "Tourism Key to the Economic Recovery of Egypt." United Nations World Tourism Organisation, 2011, Available Online at: http://media.unwto.org/en/press-release/2011-05-31/tourism-key-economic-recovery-egypt. (Accessed: 18 July 2013)

Vargas, Jose Antonio. "Spring Awakening: How an Egyptian Revolution Began on Facebook." New York Times, 2012, Available Online at: http://www.nytimes.com/2012/02/19/books/review/how-anegyptian-revolution-began-on-facebook.html?pagewanted=all\& $r=0$. (Accessed: 11 November 2013)

Verme, Paolo, Branko Milanovic, Sherine Al-Shawarby, Sahar El Tawila, May Gadallah, and Enas Ali A. El-Majeed. Inside Inequality in the Arab Republic of Egypt: Facts and Perceptions across People, Time, and Space. Washington DC: The World Bank, 2014.

Verme, Paolo. "Top Incomes and the Measurement of Inequality in Egypt." The World Bank, 2013, Available Online at: http://blogs.worldbank.org/developmenttalk/top-incomes-and-measurementinequality-egypt. (Accessed: 23 March 2014)

Waguih, Asmaa. "Egypt Protesters, Police Clash on Mubarak Anniversary." Reuters, 2013, Available Online at: http://www.reuters.com/article/2013/02/11/us-egypt-protests-

idUSBRE91A0WQ20130211. (Accessed: 15 March 2013)

Way, Lucan. "Comparing the Arab Revolts: The Lessons of 1989." Journal of Democracy 22, no. 4 (2011): 13-23.

Wedeman, Ben. "Coup Topples Egypt's Morsy; Deposed President under 'House Arrest'." CNN, 2013, Available Online at: http://edition.cnn.com/2013/07/03/world/meast/egyptprotests/index.html?hpt=hp t1. (Accessed: 2 August 2013)

Welzel, Christian, and Ronald Inglehart. "Democratization as the Growth of Freedom: The Human Development Perspective." Japanese Journal of Political Science 6, no. 03 (2006): 313-343.

Welzel, Christian, and Ronald Inglehart. "Liberalism, Postmaterialism, and the Growth of Freedom." International Review of Sociology 15, no. 1 (2005): 81-108.

Weyland, Kurt. "The Arab Spring: Why the Surprising Similarities with the Revolutionary Wave of 1848?". Perspectives on Politics 10, no. 04 (2012): 917-934.

Weyland, Kurt. "The Diffusion of Revolution: '1848' in Europe and Latin America." International Organization 63, no. 03 (2009): 391-423.

Wickham, Carrie Rosefsky. "The Muslim Brotherhood after Mubarak." In The New Arab Revolt, edited by The Council on Foreign Relations. 91-97. New York: The Council on Foreign Relations, 2011. 
Wittes, Tamara Cofman, and Richard Youngs. Europe, the United States, and Middle Eastern Democracy: Repairing the Breach. Washington DC: The Saban Centre for Middle East Policy, 2009.

World Shipping Council. "Educational Resources: The Suez Canal." World Shipping Council, 2009, Available Online at: http://www.worldshipping.org/additional-resources/educational-resources. (Accessed: 18 July 2013)

World Values Survey. "Integrated Evs/Wvs 1981-2008 Variables." World Values Survey, 2008, Available Online at: http://www.wvsevsdb.com/wvs/WVSIntegratedEVSWVSvariables.jsp?Idioma=l. (Accessed: 14 February 2014)

World Values Survey. "World Values Survey Wave 6: 2010-2014." World Values Survey, 2014, Available Online at: http://www.worldvaluessurvey.org/WVSOnline.jsp. (Accessed: 10 May 2014)

Youngs, Richard. "The Arab Spring Three Years On." The Carnegie Endowment for International Peace, 2014, Available Online at: http://carnegieeurope.eu/strategiceurope/?fa=54378. (Accessed: 11 February 2014)

Youngs, Richard. "The European Union and Democracy Promotion in the Mediterranean: A New or Disingenous Strategy?". Democratization 9, no. 1 (2002): 40-62.

Zahid, Mohammed. "The Egyptian Nexus: The Rise of Gamal Mubarak, the Politics of Succession and the Challenges of the Muslim Brotherhood." The Journal of North African Studies 15, no. 2 (2010): 217-230. 